

\section{DISCLAIMER}

This report was prepared as an account of work sponsored by an agency of the United States Government. Neither the United States Government nor any agency Thereof, nor any of their employees, makes any warranty, express or implied, or assumes any legal liability or responsibility for the accuracy, completeness, or usefulness of any information, apparatus, product, or process disclosed, or represents that its use would not infringe privately owned rights. Reference herein to any specific commercial product, process, or service by trade name, trademark, manufacturer, or otherwise does not necessarily constitute or imply its endorsement, recommendation, or favoring by the United States Government or any agency thereof. The views and opinions of authors expressed herein do not necessarily state or reflect those of the United States Government or any agency thereof. 


\section{DISCLAIMER}

Portions of this document may be illegible in electronic image products. Images are produced from the best available original document. 


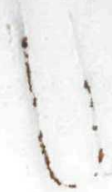

This report has been reproduced directly from the best available copy.

Available to DOE and DOE contractors from the Office of Scientific and Technical Information, P.O. Box 62, Oak Ridge, TN 37831 ; prices available from (615) 576-8401, FTS 626-8401.

Available to the public from the National Technical Information Service, U.S. Department of Commerce, 5285 Port Royal Rd., Springfield, VA 22161.

NTIS price codes-Printed Copy: AO3 Microfiche A01

This report was prepared as an account of work sponsored by an agency of the United States Government. Neither the United States Government nor any agency thereof, nor any of their employees, makes any warranty, express or implied, or assumes any legal liability or responsibility for the accuracy, completeness, or usefulness of any information, apparatus, product, or process disclosed, or represents that its use would not infringe privately owned rights. Reference herein to any specific commercial product, process, or service by trade name, trademark, manufacturer, or otherwise, does not necessarily constitute or imply its endorsement, recommendation, or favoring by the United States Government or any agency thereof. The views and opinions of authors expressed herein do not necessarily state or reflect those of the United States Government or any agency thereof. 
Engineering Physics and Mathematics

Liquid Metal Reactor Program

\title{
APPLICATION OF 3-DIMENSIONAL RADIATION TRANSPORT CODES TO THE ANALYSIS OF THE CRBR PROTOTYPIC COOLANT PIPE CHASEWAY NEUTRON STREAMING EXPERIMENT
}

\author{
K. Chatani \\ Experimental Reactor Division \\ Power Reactor and Nuclear Development Corp. \\ Ibaraki, Japan
}

August 1992

NOTICE: $\quad$ This document contains information of a preliminary nature. It is subject to revision or correction and therefore does not represent a final report.

Prepared by the

OAK RIDGE NATIONAL LABORATORY

Oak Ridge, Tennessee 37831 managed by MARTIN MARIETTA ENERGY SYSTEMS, INC. for the U.S. DEPARTMENT OF ENERGY under Contract No. DE-AC05-84OR21400 


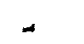

- 
LIST OF TABLES $\ldots \ldots \ldots \ldots \ldots \ldots \ldots \ldots \ldots \ldots \ldots \ldots \ldots \ldots \ldots \ldots$

LIST OF FIGURES $\ldots \ldots \ldots \ldots \ldots \ldots \ldots \ldots \ldots \ldots \ldots \ldots \ldots \ldots \ldots \ldots$

ACKNOWLEDGMENTS $\ldots \ldots \ldots \ldots \ldots \ldots \ldots \ldots \ldots \ldots \ldots \ldots \ldots \ldots \ldots \ldots$

ABSTRACT $\ldots \ldots \ldots \ldots \ldots \ldots \ldots \ldots \ldots \ldots \ldots \ldots \ldots \ldots \ldots \ldots \ldots \ldots \ldots$

1. INTRODUCTION $\ldots \ldots \ldots \ldots \ldots \ldots \ldots \ldots \ldots \ldots \ldots \ldots \ldots \ldots$

2. TWO-DIMENSIONAL ANALYSIS $\ldots \ldots \ldots \ldots \ldots \ldots \ldots \ldots \ldots \ldots$

3. DESCRIPTION OF THE CALCULATIONAL CONFIGURATION AND PARAMETERS USED IN THE THREE-DIMENSIONAL DISCRETE

ORDINATES CALCULATIONS $\ldots \ldots \ldots \ldots \ldots \ldots \ldots \ldots \ldots \ldots$

4. THREE-DIMENSIONAL DISCRETE ORDINATES CALCULATED

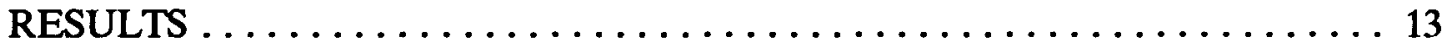

5. MORSE-CALCULATED RESULTS $\ldots \ldots \ldots \ldots \ldots \ldots \ldots \ldots \ldots \ldots \ldots$

6. COMPARISONS OF CALCULATED AND MEASURED DATA $\ldots \ldots \ldots \ldots 26$

7. CONCLUSIONS ............................... 49

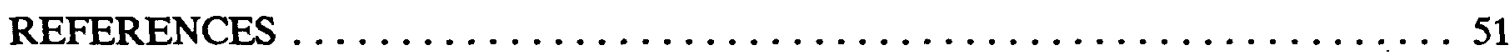

APPENDIX I - COMPARISON OF TORT AND ENSEMBLE RESULTS FOR TEST CALCULATIONS USING A DUMMY SOURCE $\ldots \ldots \ldots \ldots \ldots \ldots 5$

APPENDIX II - DETAILED MORSE-CALCULATED RESULTS $\ldots \ldots \ldots \ldots \ldots$ 


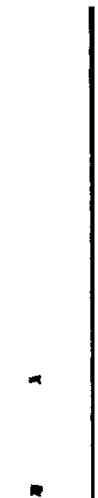




\section{LIST OF TABLES}

Table 1. Energy Boundaries for the 21-Neutron-Group Structure $\ldots \ldots \ldots \ldots \ldots \ldots$

Table 2. Parameters Used in the Three-Dimensional Discrete Ordinates Transport Calculations ............................... 9

Table 3-1. Angular Quadrature Set Used in the TORT Calculations (60 Directions) . 10

Table 3-2. Angular Quadrature Set Used in the ENSEMBLE Calculation (Fully

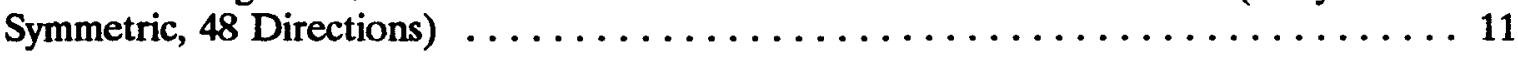

Table 4. Convergence Statistics (Numbers of Iterations and Flux Errors) by Group for the TORT and ENSEMBLE Calculations $\ldots \ldots \ldots \ldots \ldots \ldots \ldots \ldots$

Table 5-1. Comparison of Calculated and Measured Bare Bonner Ball Count Rates Along the Centerline of the First Leg of the Chaseway $\ldots \ldots \ldots \ldots \ldots \ldots \ldots 28$

Table 5-2. Comparison of Calculated and Measured 2-inch Bonner Ball Count Rates Along the Centerline of the First Leg of the Chaseway ............. 39

Table 5-3. Comparison of Calculated and Measured 3-inch Bonner Ball Count Rates Along the Centerline of the First Leg of the Chaseway $\ldots \ldots \ldots \ldots \ldots \ldots$

Table 5-4. Comparison of Calculated and Measured 6-inch Bonner Ball Count Rates Along the Centerline of the First Leg of the Chaseway

Table 5-5. Comparison of Calculated and Measured 10-inch Bonner Ball Count

Rates Along the Centerline of the First Leg of the Chaseway $\ldots \ldots \ldots \ldots \ldots . \ldots 4$

Table 6-1. Comparison of Calculated and Measured Bare Bonner Ball Count Rates Along the Centerline of the Second Leg of the Chaseway $\ldots \ldots \ldots \ldots \ldots 43$

Table 6-2. Comparison of Calculated and Measured 2-inch Bonner Ball Count Rates Along the Centerline of the Second Leg of the Chaseway ............ 44

Table 6-3. Comparison of Calculated and Measured 3-inch Bonner Ball Count Rates Along the Centerline of the Second Leg of the Chaseway ........... 45

Table 6-4. Comparison of Calculated and Measured 6-inch Bonner Ball Count Rates Along the Centerline of the Second Leg of the Chaseway ............ 46

Table 6-5. Comparison of Calculated and Measured 10-inch Bonner Ball Count Rates Along the Centerline of the Second Leg of the Chaseway ...........47

Table A.I. Flux Error (\%) by Iteration of the Test Calculation Neutron Fluxes for Groups 20 and 21 


\section{LIST OF FIGURES (Cont'd)}

Fig. 10-2. Comparison of Calculated and Measured 6-inch and 10-inch Bonner Ball Count Rates $\left(\mathrm{min}^{-1} \cdot \mathrm{W}^{-1}\right)$ Along the Centerline of the First Leg of the Chaseway .

Fig. 11-1. C/E Values for the Bare Bonner Ball Count Rate Along the Centerline of the First Leg of the Chaseway

Fig. 11-2. C/E Values for the 2-inch Bonner Ball Count Rate Along the Centerline of the First Leg of the Chaseway

Fig. 11-3. C/E Values for the 3-inch Bonner Ball Count Rate Along the Centerline of the First $\mathrm{Leg}$ of the Chaseway $\ldots \ldots \ldots \ldots \ldots \ldots \ldots \ldots \ldots \ldots$

Fig. 12-1. Comparison of Calculated and Measured Bare, 2-inch, and 3-inch Bonner Ball Count Rates $\left(\mathrm{min}^{-1} . \mathrm{W}^{-1}\right)$ Along the Centerline of the Second Leg of the Chaseway

Fig. 12-2. Comparison of Calculated and Measured 6-inch and 10-inch Bonner Ball Count Rates $\left(\mathrm{min}^{-1} . \mathrm{W}^{-1}\right)$ Along the Centerline of the Second Leg of the Chaseway

Fig. 13-1. C/E Values for the Bare Bonner Ball Count Rate Along the Centerline of the Second Leg of the Chaseway

Fig. 13-2. C/E Values for the 2-inch Bonner Ball Count Rate Along the Centerline of the Second Leg of the Chaseway

Fig. 13-3. C/E Values for the 3-inch Bonner Ball Count Rate Along the Centerline of the Second Leg of the Chaseway $\ldots \ldots \ldots \ldots \ldots \ldots \ldots \ldots \ldots$

Fig. A.I. Convergence by Iteration of the Test Calculation Neutron Fluxes

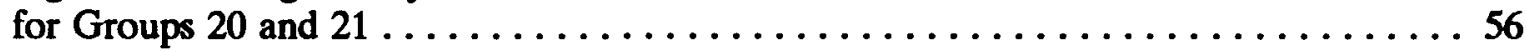




\section{ACKNOWLEDGMENTS}

The author wishes to thank C. O. Slater for his patiently helping in the calculation, and D. T. Ingersoll, J. V. Pace, III, and W. A. Rhoades for thieir generous consulting and recommendations.

Also appreciation is expressed to N. Ohtani of Power Reactor and Nuclear Fuel Corp., O. Sato of Mitsubishi Research Institute Inc., T. Ohta of Mitsubishi Atomic Power Industries Inc., and T. Ishikawa of Century Research Center Corporation for their participation in the calculations and analyses in Japan.

Special thanks go to C. R. Householder, A. C. Alford, and C. O. Slater for their efforts in editing and preparing this report. 


\begin{abstract}
This report summarizes the calculational results from analyses of a Clinch River Breeder Reactor (CRBR) prototypic coolant pipe chaseway neutron streaming experiment. Comparisons of calculated and measured results are presented, major emphasis being placed on results at bends in the chaseway.

Calculations were performed with three three-dimensional radiation transport codes: the discrete ordinates code TORT and the Monte Carlo code MORSE, both developed by the Oak Ridge National Laboratory (ORNL), and the discrete ordinates code ENSEMBLE, developed by Japan. The calculated results from the three codes are compared (1) with previously-calculated DOT3.5 two-dimensional results, (2) among themselves, and (3) with measured results. Calculations with TORT used both the weighted-difference and nodal methods. Only the weighted-difference method was used in ENSEMBLE.

While the TORT- and ENSEMBLE-calculated results agreed well, the two codes differed in the number of iterations required to converge the fluxes for each group. Additionally, the TORT weighted-difference and nodal calculations showed no appreciable difference in the number of iterations required for convergence. However, there was a noticeable difference in the computer CPU times and some difference in the calculational results.

When the calculated results were compared to measured results, it was found that calculation-to-experiment $(\mathrm{C} / \mathrm{E})$ ratios were good in the regions of the chaseway where two-dimensional modeling might be difficult and where there were no significant discrete ordinates ray effects. Excellent agreement was observed for responses dominated by thermal neutron contributions. MORSE-calculated results and comparisons are described also, and detailed results are presented in an appendix.
\end{abstract}




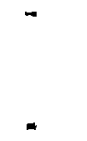




\section{INTRODUCTION}

In 1976 and 1977, an experiment was conducted at the Oak Ridge National Laboratory's (ORNL's) Tower Shielding Facility (TSF) to evaluate neutron streaming in a Clinch River Breeder Reactor (CRBR) prototypic coolant pipe chaseway. ${ }^{1}$ The chaseway contained two right-angle bends and was surrounded by concrete. Neutron flux measurements, using Bonner balls, indicated nine orders of attenuation in the empty pipeway. The ORNL measurement data were made available to Power Reactor and Nuclear Fuel Development Corporation (PNC) through the CRBR and MONJU, Japanese prototype fast breeder reactor, information exchange. ${ }^{2}$

Data from this experiment have been used in the verification of the three-dimensional (3-D) discrete ordinates radiation transport computer code ENSEMBLE ${ }^{3,4,5,6}$, which was

developed in Japan. Recently, an updated analysis of the experiment was performed using the 3-D discrete ordinates radiation transport computer code $\mathrm{TORT}^{7}$, which was developed at ORNL. Previously, analyses had been performed in Japan using the ENSEMBLE code and the ORNL-developed radiation transport computer codes MORSE $^{8}$ (3-D Monte Carlo) and DOT3.5 (two-dimensional [2-D] discrete ordinates). This report describes the calculations and presents intercomparisons of the calculated results as well as comparisons of calculated and measured results.

While the experimental configurations consisted of the pipe chaseway with and without a coolant pipe mockup, the analyses were limited to the configuration without a coolant pipe mockup because more measurements were made at the bends in the chaseway in those configurations. The data at the bends were important because of the anticipated difficulties in calculating the neutron flux at the bends, particularly with DOT3.5. The configuration without a coolant pipe mockup is shown in Fig. 1. The figure also shows the portion of the configuration calculated with the 3-D codes and the paths of the Bonner ball traverses (large arrows on the figure). Also, the figure shows a spectrum modifier between the Tower Shielding Reactor (TSR) and the chaseway mockup. The spectrum modifier consists of $30.5 \mathrm{~cm}$ of stainless steel followed by $152.4 \mathrm{~cm}$ of sodium in a large tank. The end of the sodium tank is about $197 \mathrm{~cm}$ from the exit face of the TSR neutron beam collimator. Distances along the centerlines of the three legs of the chaseway measure about 307,770 , and $396 \mathrm{~cm}$. Maximum traverse distances in the three legs are about 457, 983, and $560 \mathrm{~cm}$. However, because of the Bonner ball sizes and the limitations of the traversing mechanism, the traverse distances for the measurements were somewhat less than the maximum distances.

At the time of these analyses, the 3-D discrete ordinates codes were still under development and experience using the codes was relatively little. Therefore, a comparison of TORT and ENSEMBLE options and calculational performance was deemed appropriate. Data are presented on the input parameters, the convergence rate, the CPU times, and the number of iterations used to converge the flux to the requested deviation. 


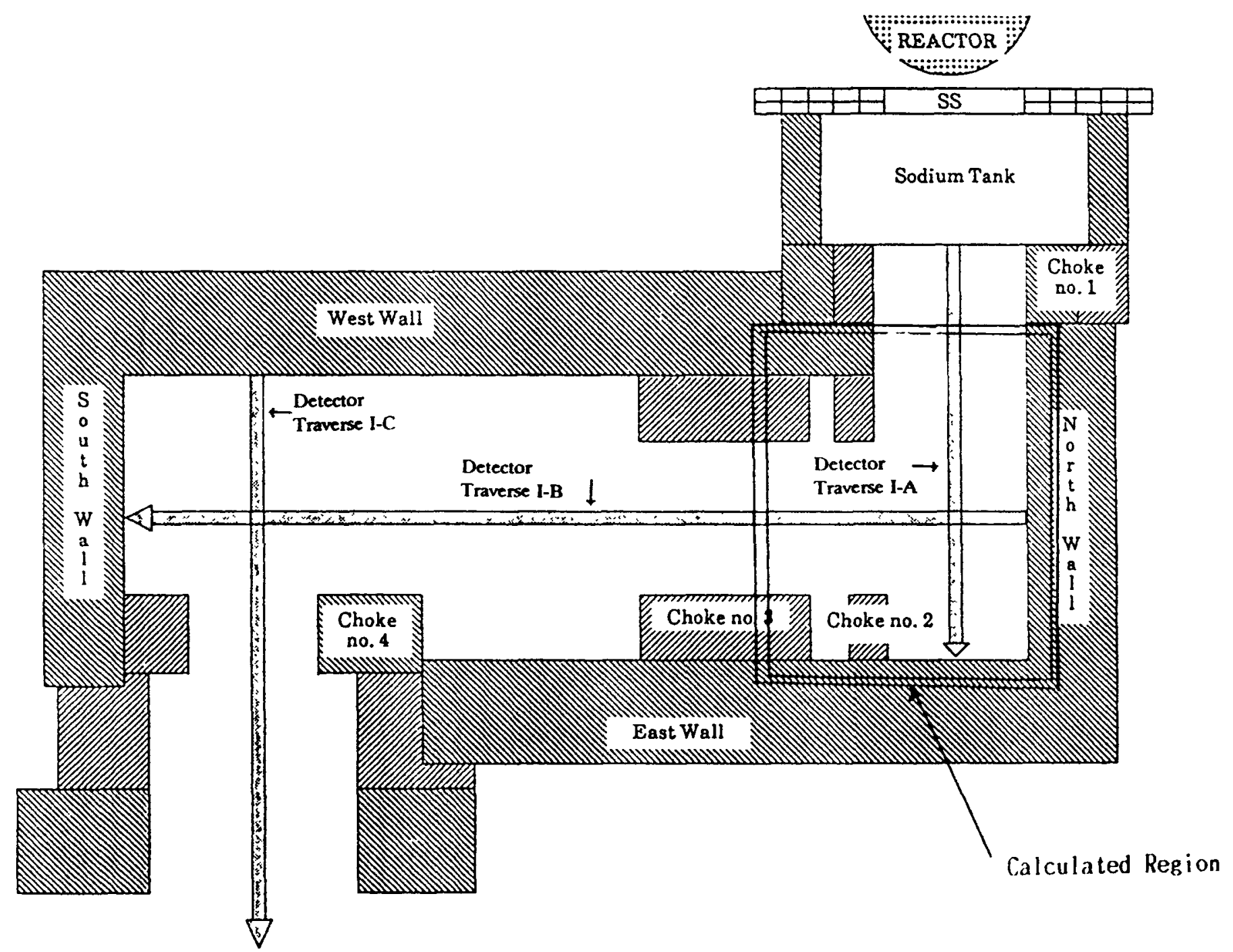

Fig. 1. Experimental Arrangement and Bonner Ball Detector Traverses. 


\section{TWO-DIMENSIONAL ANALYSIS}

The experiment was originally analyzed at $O R N L^{10}$ using DOT3.5. The right-angle bends in the experimental configuration as well as the shape of the chaseway made the 2-D modeling difficult. A separate DOT3.5 calculation was performed for each leg of the chaseway with transformed boundary fluxes from the first and second leg calculations providing the source for the second and third legs, respectively.

The 2-D analysis required three major approximations. The first approximation was the use of circular geometry to model the rectangular cross section of the chaseway. This is not seen as a major problem when calculating fluxes along the centerline of a straight duct. Agreement between calculated and measured results should get worse as the distance from the centerline increases.

The second and third approximations resulted because of the manner in which the 2-D calculation had to be performed (i.e. a separate DOT3.5 calculation for each leg of the chaseway). The second approximation was the modeling of the first-leg geometry with concrete closing the entrance to the second leg of the chaseway. A similar approximation was made for the calculation in the second leg of the chaseway. The effect of this modeling approximation should be to overestimate the flux in the region near the junction of the two legs, since the concrete allows less leakage than the open duct would. On the other hand, the modeling of choke no. 2 as two $152.4-\mathrm{cm}-\mathrm{ID}$ by $254-\mathrm{cm}-\mathrm{OD}$ by 89.4-cm-thick concrete disks sandwiching a 152.4-cm-thick void disk (representing the opening of choke no. 2), appears to allow more leakage from the first leg. This could offset part of the first-leg flux increase that was caused by backscatter from the concrete enclosing the second-leg entrance in the 2-D geometry model.

The third approximation involved the calculation of the neutron source entering the second and third legs. The axially-varying source at the side (curved surface) of one cylinder is transformed to a radially-varying source on the end (flat surface) of a cylinder at a right angle to it. In the transformation process, the asymmetrical flux distribution along the chaseway walls at the entrance to the second or third leg of the chaseway is changed to a distribution that is azimuthally uniform in space. While measured data along the centerline may be predicted well using such a source, measured data along the walls could be overpredicted or underpredicted, depending on how the scattered neutrons are focused within the chaseway.

Two-dimensional calculations similar to ORNL's were also performed in Japan. These calculations used a 21-neutron energy group structure, and a biased, 124-direction quadrature set. Cross-section data in a 100-group structure with $\mathrm{P}_{5}$ scattering were obtained from the ENDF/B-IV DLC2D library ${ }^{11}$ and were collapsed, using ANISN $^{12}$ flux spectra, to the 21-group structure defined in Table 1. The quadrature set, biased in the $+\eta$ direction (109 directions with positive $\eta$ 's compared to 15 with negative $\eta$ 's), is suited for straight-ahead streaming problems, but it is not particularly well suited for calculating streaming around bends. The spatial mesh consisted of 45 radial and 131 axial intervals in the first leg and 35 radial and 208 axial intervals in the second leg. 


\begin{tabular}{|c|c|c|c|c|}
\hline No. & $\begin{array}{l}\text { Corresponding } \\
\text { DLC2D Groups }\end{array}$ & \multicolumn{2}{|c|}{ Energy Range (eV) } & $\begin{array}{l}\text { Lethargy } \\
\text { Width }\end{array}$ \\
\hline 1 & $01-10$ & $1.4918+7$ & $5.4881+6$ & 1.0 \\
\hline 2 & $11-15$ & $5.4881+6$ & $3.3287+6$ & 0.5 \\
\hline 3 & $16-20$ & $3.3287+6$ & $2.0190+6$ & 0.5 \\
\hline 4 & $21-25$ & $2.0190+6$ & $1.2246+6$ & 0.5 \\
\hline 5 & $26-30$ & $1.2246+6$ & $7.4274+5$ & 0.5 \\
\hline 6 & $31-35$ & $7.4274+5$ & $4.5049+5$ & 0.5 \\
\hline 7 & $36-40$ & $4.5049+5$ & $2.7324+5$ & 0.5 \\
\hline 8 & $41-45$ & $2.7324+5$ & $1.6573+5$ & 0.5 \\
\hline 9 & $46-51$ & $1.6573+5$ & $6.7379+4$ & 0.9 \\
\hline 10 & $52-55$ & $6.7379+4$ & $2.4788+4$ & 1.0 \\
\hline 11 & $56-59$ & $2.4788+4$ & $9.1188+3$ & 1.0 \\
\hline 12 & $60-63$ & $9.1188+3$ & $3.3546+3$ & 1.0 \\
\hline 13 & $64-67$ & $3.3546+3$ & $1.2341+3$ & 1.0 \\
\hline 14 & $68-71$ & $1.2341+3$ & $4.5400+2$ & 1.0 \\
\hline 15 & $72-75$ & $4.5400+2$ & $1.6702+2$ & 1.0 \\
\hline 16 & $76-80$ & $1.6702+2$ & $4.7551+1$ & 1.25 \\
\hline 17 & $81-85$ & $4.7551+1$ & $1.3710+1$ & 1.25 \\
\hline 18 & $86-90$ & $1.3710+1$ & $3.9279+0$ & 1.25 \\
\hline 19 & $91-95$ & $3.9279+0$ & $1.1254+0$ & 1.25 \\
\hline 20 & $96-99$ & $1.1254+0$ & $4.1399-1$ & 1.00 \\
\hline 21 & 100 & $4.1399-1$ & $1.0000-3$ & - \\
\hline
\end{tabular}


The source for the calculation was constructed from axial boundary fluxes obtained from a DOT3.5 calculation of the transmission of Tower Shielding Reactor neutrons through a spectrum modifier consisting of $30.5 \mathrm{~cm}$ of stainless steel and $152.4 \mathrm{~cm}$ of sodium. Internal boundary fluxes at the interface between the stainless steel and the sodium tank were output from that calculation and served as the source for the DOT3.5 calculation in the first leg of the chaseway mockup. In turn, boundary fluxes at the end of choke no. 1 from the first-leg DOT3.5 calculation served as a source for the 3-D calculations to be discussed later.

Results from the 2-D calculations are compared with measured results in Fig. 2. At the bends, the curves for the calculated results overlap because results were obtained from separate calculations in three legs. The measured results also overlap because of the overlapping traverses shown in Fig. 1. As expected, the results at the bends are in worse agreement than elsewhere. Agreement is generally good in the first and second legs, but the calculations significantly overpredict the measured results in the third leg.

Overprediction is seen at the entrance of the second leg in part due to the higher first-leg flux levels caused by the manner in which the entrance to the second leg of the chaseway was modeled in the first-leg calculation. The sharp drops in the calculated curves are due to flux attenuation by the concrete at the ends of the first and second legs. The sharp drops are not indicative of poor agreement between the calculated and measured results. In fact, the calculated results agree well with the measured results up to the last measurement location along traverses $\mathrm{A}$ and $\mathrm{B}$ of Fig. 1. 


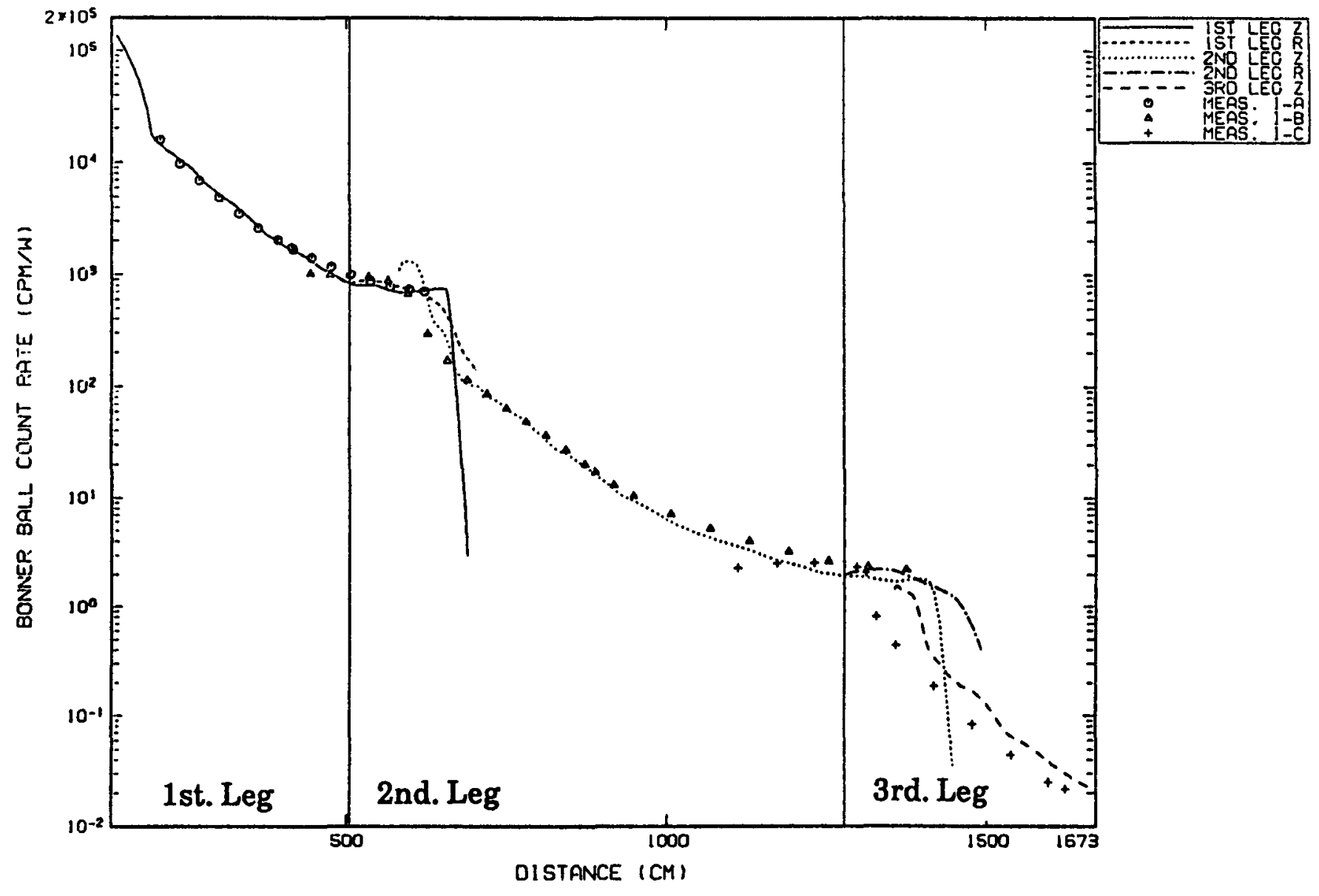

a

Fig. 2. Comparison of the Measured and DOT3.5-Calculated 3-inch Bonner Ball Count Rates $\left(\mathrm{min}^{-1} . \mathrm{W}^{-1}\right)$ Along the Axis of the CRBR Prototypic Coolant Pipe Empty Chaseway Mockup. 


\section{DESCRIPTION OF THE CALCULATIONAL CONFIGURATION AND PARAMETERS USED IN THE THREE-DIMENSIONAL DISCRETE ORDINATES CALCULATIONS}

The 3-D codes, TORT, ENSEMBLE, and MORSE, were used to analyze the measured data at the bend between the first and second legs of a CRBR prototypic coolant pipe chaseway experimental mockup. The portion of the experimental configuration modeled in the 3-D calculations is shown in Fig. 1. Details of the geometry model for the TORT and ENSEMBLE calculations are shown in Fig. 3. The latter figure shows the number of spatial mesh intervals to be 60, 65, and 30 along the $x-, y-$, and $z$-axes, respectively ( $z-, x$-, and $y$-axes for ENSEMBLE). These mesh intervals represent a total of 117,000 mesh cells.

Some key parameters for the TORT and ENSEMBLE calculations are shown in Table 2. The following comments are made regarding the items listed in the table. First, both calculations use X-Y-Z geometry. However, as noted above, the alignment of the experimental configuration along the coordinate axes is different between the TORT and ENSEMBLE calculations. Second the number of groups used is 21 (all neutron). Third, the TORT quadrature, which is listed in Table 3-1, has 60 directions, while the ENSEMBLE quadrature, which is listed in Table 3-2, has 48 directions. The two quadrature sets are of the same order, but the ENSEMBLE quadrature does not have any zero-weight directions. While the TORT quadrature contains zero-weight directions, TORT does not use them in the calculation. The completely symmetric ENSEMBLE quadrature set was generated and checked with the $D O Q^{13}$ code. Fourth, different $P_{n}$ expansions of the scattering cross section were used: $P_{3}$ for TORT and $P_{1}$ for ENSEMBLE. The lower order expansion requires less computer memory and is probably adequate, since the streaming contribution probably dominates the wall-scattered contribution over the region of the geometry analyzed. Fifth, the number of spatial mesh is the same, but, as stated above, the two sets of coordinate axes are oriented differently with respect to the experimental configuration. Sixth, the acceleration technique for TORT was "stabilized partial current rebalance", and that for ENSEMBLE was "coarse mesh rebalance". TORT used relatively few coarse mesh cells (75) compared to ENSEMBLE's 23,370. ENSEMBLE turns off its acceleration method during the iteration process after the flux error is within a specified range about the convergence criterion. TORT has no user options for turning off the acceleration during iteration. Seventh, both codes used the same point flux convergence criterion of a $1 \%$ change in the scalar fluxes between iterations. Eighth and finally, TORT calculations were performed with both the weighted-difference and linear nodal methods. The ENSEMBLE calculation was performed with a weighted-difference method that is equivalent to the zero-weighted method in TORT.

For the ENSEMBLE calculation, the weighted-difference and acceleration methods were selected based on previous calculational experience. The methods were not verified as being the best or optimal selections for the calculation.

The neutron boundary source for the 3-D calculations was input at the exit surface of choke no. 1. As stated in Sect. 2, the source was output from a DOT3.5 calculation in the 


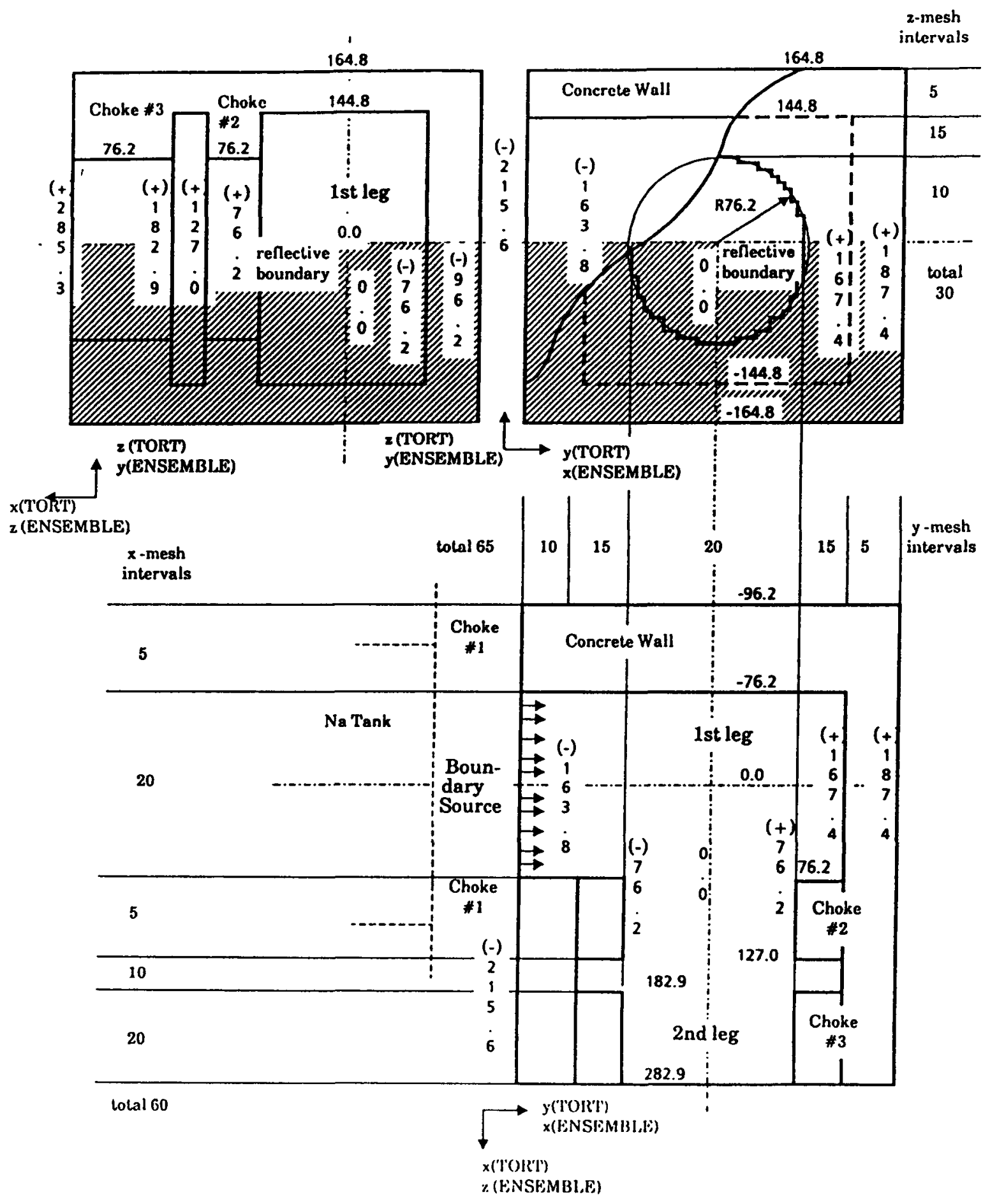

Fig. 3. Geometry Model for the Three-Dimensional Discrete Ordinates Calculations. 


\begin{tabular}{|c|c|c|}
\hline ITEM & TORT & ENSEMBLE \\
\hline Geometry & 3-D X-Y-Z & 3-D X-Y-Z \\
\hline Energy Groups (Neutron) & 21 & 21 \\
\hline (Gamma) & $\mathbf{0}$ & $\mathbf{0}$ \\
\hline S-N (Number of Directions) & 60 & 48 \\
\hline P-L & 3 & 1 \\
\hline Spatial Meshes $(\mathbf{x}, \mathrm{y}, \mathbf{z})$ & $60 \times 65 \times 30$ & $65 \times 30 \times 60$ \\
\hline Boundary Conditions $\mathrm{x}$ min. & Vacuum & Boundary Source \\
\hline$x \max$. & Vacuum & Vacuum \\
\hline y min. & Boundary Source & Vacuum \\
\hline y max. & Vacuum & Reflective \\
\hline $\mathrm{z}$ min. & Reflective & Vacuum \\
\hline $\mathrm{z} \max$. & Vacuum & Vacuum \\
\hline Acceleration & $\begin{array}{l}\text { Stabilized Partial } \\
\text { Current Rebalance }\end{array}$ & $\begin{array}{c}\text { Coarse Mesh } \\
\text { Rebalance }\end{array}$ \\
\hline Coarse Meshes & $5 \times 5 \times 3$ & $41 \times 19 \times 30$ \\
\hline Convergence Criteria & $1 \%$ & $1 \%$ \\
\hline Difference Equation & Weighted and Nodal ${ }^{2}$ & Weighted \\
\hline
\end{tabular}

'The source multiplier parameter ("theta") was 0.9 for weighted and 1.0 for nodal. 
Table 3-1. Angular Quadrature Set Used in the TORT Calculations (60 Directions).

\begin{tabular}{|c|c|c|c|c|c|c|c|c|c|}
\hline No & $\mu$ & $\eta$ & $\xi$ & Weight & No & $\mu$ & $\eta$ & $\xi$ & Weight \\
\hline 1 & .36515 & -0.93095 & 0. & 0. & 31 & -0.36515 & 0.93095 & 0. & 0. \\
\hline 2 & -0.25820 & -0.93095 & -0.25820 & 0.0208335 & 32 & -0.25820 & 0.93095 & -0.25820 & 0 \\
\hline 3 & & & & & 33 & & & & \\
\hline 4 & -0.73030 & -0.68313 & 0. & 0. & 34 & -0.73030 & 0.68313 & 0. & 0. \\
\hline 5 & -0.6 & -0.6 & -0.25820 & 0.0208335 & 35 & -0.6 & 0.68313 & -0.25820 & 0.0208335 \\
\hline 6 & -0.2 & -0.6 & -0.68 & 0.020 & 36 & & & & \\
\hline 7 & & -0.68313 & -0.68313 & 0.0208335 & 37 & 0.25820 & 0.68313 & -0.68313 & \\
\hline 8 & 0.68313 & -0.68313 & -0.25820 & 0.0208335 & 38 & 0.68313 & 0.68313 & -0.25820 & 0.0208335 \\
\hline 9 & & & 0. & 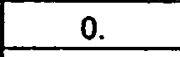 & 39 & & & 0. & \\
\hline 10 & -0.9 & -0.25820 & -0.25820 & 0.0208335 & 40 & -0.9 & 0.2 & -0.25820 & 0.0208 \\
\hline 11 & -0.68313 & -0.25820 & -0.68313 & 0.0208335 & 41 & -0.68313 & 0.25820 & -0.68313 & 0.0208335 \\
\hline 12 & -0.2 & -0.25820 & -0.9 & 335 & 42 & & & & \\
\hline 13 & 320 & -0.25820 & -0.93095 & 0.02 & 43 & 0.25820 & 0.25 & -0.93095 & 0.02 \\
\hline 14 & 0.68313 & 820 & -0.68313 & 88335 & 44 & 0.68 & & 313 & 335 \\
\hline 15 & 0.93 & -0 & -0.25820 & 0.0208335 & 45 & 0.9 & 0.2 & -0.2 & 335 \\
\hline 16 & -0.3 & -0.9 & 0. & 0. & 46 & -0.3 & & 0. & 0. \\
\hline 17 & -0.2 & \begin{tabular}{|l|}
-0.93095 \\
\end{tabular} & 0.25 & 0.0208335 & 47 & -0.25820 & 0.9 & 820 & 8335 \\
\hline 18 & 0.25820 & -0.93095 & 0.25820 & 0.0208335 & 48 & 0.25820 & 0.9 & 0.25820 & 0.0208335 \\
\hline 19 & -0.73030 & -0.68313 & 0. & 0. & 49 & -0.73030 & 0.68313 & 0. & 0. \\
\hline 20 & -0.68313 & -0.68313 & 0.2 & 0.0208335 & 50 & -0.68313 & 0.68313 & 320 & 208335 \\
\hline 21 & -0.25820 & 0.68313 & 0.68313 & 0.0208335 & 51 & -0.25820 & 0.68313 & 0.68313 & 0.0208335 \\
\hline 22 & 0.25820 & -0.68313 & 0.68313 & 0.0208335 & 52 & 0.25820 & 0.68313 & 0.68313 & 0.0208335 \\
\hline 23 & 0.68313 & -0.6 & 0.25820 & 0.0208335 & 53 & 0.68313 & 0.6 & 0.25820 & 0.0208335 \\
\hline 24 & -0.96609 & -0.25820 & 0. & 0. & 54 & \begin{tabular}{|c|}
-0.96609 \\
\end{tabular} & 0.25820 & 0. & 0. \\
\hline 25 & -0.93095 & -0.25820 & 0.2 & 0208335 & 55 & -0.93095 & 0.25820 & 20 & 0.0208335 \\
\hline 26 & -0.68313 & -0.25820 & 0.68313 & 0.0208335 & 56 & \begin{tabular}{|c|}
-0.68313 \\
\end{tabular} & 0.25820 & 0.68313 & 0.0208335 \\
\hline 27 & -0.25820 & -0.25820 & 0.93095 & 0.0208335 & 57 & -0.25820 & 0.25820 & 0.9 & 0.0208335 \\
\hline 28 & 0.25820 & -0.25820 & 0.93095 & 0.0208335 & 58 & 0.25820 & 0.25820 & 0.93095 & 0.0208335 \\
\hline 29 & 0.68313 & -0.25820 & 0.68313 & 0.0208335 & 59 & 0.68313 & 0.25820 & 0.68313 & 0.0208335 \\
\hline 30 & 0.93095 & -0.25820 & 0.25820 & .0208335 & 60 & 0.93095 & 0.25820 & 0.25820 & 0.0208335 \\
\hline
\end{tabular}


Table 3-2. Angular Quadrature Set Used in the ENSEMBLE Calculation (Fully Symmetric, 48 Directions.)

\begin{tabular}{|c|c|c|c|c|}
\hline ANGL & MYU & ETA & GLA.I & WE IGHT \\
\hline 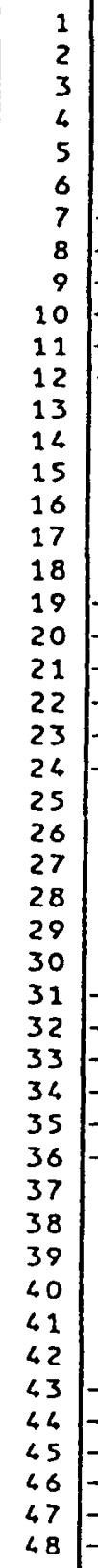 & $\begin{array}{r}2.66634 E-01 \\
6.81504 E-01 \\
2.66634 E-01 \\
9.26177 E-01 \\
6.81504 E-01 \\
2.66634 E-01 \\
-2.66634 E-01 \\
-6.81504 E-01 \\
-2.66634 E-01 \\
-9.26177 E-01 \\
-6.81504 E-01 \\
-2.66634 E-01 \\
2.66634 E-01 \\
6.81504 E-01 \\
2.66634 E-01 \\
9.26177 E-01 \\
6.81504 E-01 \\
2.66634 E-01 \\
-2.66634 E-01 \\
-6.81504 E-01 \\
-2.66634 E-01 \\
-9.26177 E-01 \\
-6.81504 E-01 \\
-2.66634 E-01 \\
2.66634 E-01 \\
6.81504 E-01 \\
2.66634 E-01 \\
9.26177 E-01 \\
6.81504 E-01 \\
2.66634 E-01 \\
-2.66634 E-01 \\
-6.81504 E-01 \\
-2.66634 E-01 \\
-9.26177 E-01 \\
-6.81504 E-01 \\
-2.66634 E-01 \\
2.66634 E-01 \\
6.81504 E-01 \\
2.66636 E-01 \\
9.26177 E-01 \\
6.81504 E-01 \\
2.66634 E-01 \\
-2.66634 E-01 \\
-6.81504 E-01 \\
-2.66634 E-01 \\
-9.26177 E-01 \\
-6.81504 E-01 \\
-2.66634 E-01\end{array}$ & $\begin{array}{l}-9.26177 E-01 \\
-6.81504 E-01 \\
-6.81504 E-01 \\
-2.66634 E-01 \\
-2.66634 E-01 \\
-2.66634 E-01 \\
-9.26177 E-01 \\
-6.81504 E-01 \\
-6.81504 E-01 \\
-2.66634 E-01 \\
-2.66634 E-01 \\
-2.66634 E-01 \\
9.26177 E-01 \\
6.81504 E-01 \\
6.81504 E-01 \\
2.66634 E-01 \\
2.66636 E-01 \\
2.66634 E-01 \\
9.26177 E-01 \\
6.81504 E-01 \\
6.81504 E-01 \\
2.66634 E-01 \\
2.66634 E-01 \\
2.66634 E-01 \\
-9.26177 E-01 \\
-6.81504 E-01 \\
-6.81504 E-01 \\
-2.66634 E-01 \\
-2.66634 E-01 \\
-2.66634 E-01 \\
-9.26177 E-01 \\
-6.81504 E-01 \\
-6.81504 E-01 \\
-2.66634 E-01 \\
-2.66634 E-01 \\
-2.66634 E-01 \\
9.26177 E-01 \\
6.81504 E-01 \\
6.81504 E-01 \\
2.66634 E-01 \\
2.66634 E-01 \\
2.66634 E-01 \\
9.26177 E-01 \\
6.81504 E-01 \\
6.81504 E-01 \\
2.66634 E-01 \\
2.66634 E-01 \\
2.66634 E-01\end{array}$ & $\begin{array}{l}-2.66652 E-01 \\
-2.66652 E-01 \\
-6.81511 E-01 \\
-2.66652 E-01 \\
-6.81511 E-01 \\
-9.26182 E-01 \\
-2.66652 E-01 \\
-2.66652 E-01 \\
-6.81511 E-01 \\
-2.66652 E-01 \\
-6.81511 E-01 \\
-9.26182 E-01 \\
-2.66652 E-01 \\
-2.66652 E-01 \\
-6.81511 E-01 \\
-2.66652 E-01 \\
-6.81511 E-01 \\
-9.26182 E-01 \\
-2.66652 E-01 \\
-2.66652 E-01 \\
-6.81511 E-01 \\
-2.66652 E-01 \\
-6.81511 E-01 \\
-9.26182 E-01 \\
2.66652 E-01 \\
2.66652 E-01 \\
6.81511 E-01 \\
2.66652 E-01 \\
6.81511 E-01 \\
9.26182 E-01 \\
2.66652 E-01 \\
2.66652 E-01 \\
6.81511 E-01 \\
2.66652 E-01 \\
6.81511 E-01 \\
9.26182 E-01 \\
2.66652 E-01 \\
2.66652 E-01 \\
6.81511 E-01 \\
2.66652 E-01 \\
6.81511 E-01 \\
9.26182 E-01 \\
2.66652 E-01 \\
2.66652 E-01 \\
3.81511 E-01 \\
2.66652 E-01 \\
6.81511 E-01 \\
9.26182 E-01\end{array}$ & $\begin{array}{l}2.20157 E-02 \\
1.96508 E-02 \\
1.96508 E-02 \\
2.20157 E-02 \\
1.96508 E-02 \\
2.20157 E-02 \\
2.20157 E-02 \\
1.96508 E-02 \\
1.96508 E-02 \\
2.20157 E-02 \\
1.96508 E-02 \\
2.20157 E-02 \\
2.20157 E-02 \\
1.96508 E-02 \\
1.96508 E-02 \\
2.20157 E-02 \\
1.96508 E-02 \\
2.20157 E-02 \\
2.20157 E-02 \\
1.96508 E-02 \\
1.96508 E-02 \\
2.20157 E-02 \\
1.96508 E-02 \\
2.20157 E-02 \\
2.20157 E-02 \\
1.96508 E-02 \\
1.96508 E-02 \\
2.20157 E-02 \\
1.96508 E-02 \\
2.20157 E-02 \\
2.20157 E-02 \\
1.96508 E-02 \\
1.96508 E-02 \\
2.20157 E-02 \\
1.96508 E-02 \\
2.20157 E-02 \\
2.20157 E-02 \\
1.96508 E-02 \\
1.96508 E-02 \\
2.20157 E-02 \\
1.96508 E-02 \\
2.20157 E-02 \\
2.20157 E-02 \\
1.96508 E-02 \\
1.96508 E-02 \\
2.20157 E-02 \\
1.96508 E-02 \\
2.20157 E-02\end{array}$ \\
\hline
\end{tabular}


first leg of the chaseway mockup. A small amount of the measured neutron leakage from the choke concrete was neglected in the calculations. The 3-D boundary source was produced by using the "nearest-neighbor method" to transform the first-leg boundary fluxes from the 124-direction, biased quadrature of the 2-D calculation into 60- (for TORT) or 48-direction (for EMSEMBLE) quadrature boundary fluxes. After the transformation, the 3-D boundary fluxes were normalized such that the neutron current at the source boundary was preserved.

- For a given output quadrature set direction, the nearest neighbor is that input quadrature set direction which forms the largest dot product with the output quadrature set direction. 


\section{THREE-DIMENSIONAL DISCRETE ORDINATES CALCULATED RESULTS}

The TORT calculations were made on the Martin Marietta Energy System's CRAYXMP computer at Oak Ridge, Tennessee, and the ENSEMBLE calculations were made on the FACOM-VP100 and FACOM M780-10S computers at PNC in Japan. The numbers of inner iterations for each energy group and the scalar flux errors at each final iteration are shown in Table 4. The flux convergence criterion was defined as $1 \%$, and all groups converged to $1 \%$ or less within the iteration limit except for the thermal group. In order to save computer time, the thermal group flux was not converged after it was confirmed that the fluxes at key points in the calculational configuration were converged. Fig. 4 shows the convergence of the thermal-neutron flux by iteration for the TORT and ENSEMBLE calculations. In the TORT calculation using the nodal method, the calculated thermal-neutron fluxes tended to converge, but the fluxes calculated using the weighted-difference method oscillated and were difficult to converge.

A comparison of CPU times and numbers of iterations is shown in the following table:

\begin{tabular}{cccccc}
\hline Code & Method & Machine & $\begin{array}{c}\text { Number of } \\
\text { Iterations }\end{array}$ & $\begin{array}{c}\text { CPU Time } \\
\text { (min) }\end{array}$ & $\begin{array}{c}\text { CPU Time } \\
\text { /teration } \\
(\mathrm{min})\end{array}$ \\
\hline TORT & Nodal & Cray-XMP & 330 & 338 & 0.98 \\
TORT & Weighted & Cray-XMP & 343 & 158 & 0.46 \\
ENSEMBLE & Weighted & FACOM-VP100 & 473 & 648 & 1.29 \\
& & & $499^{*}$ & & \\
\hline
\end{tabular}

*The value of 499 includes the loss at the restart and recalculation.

Compared to the weighted-difference method, the nodal method gives comparable accuracy using coarser spatial meshes. However, for the spatial mesh used in the calculations, the nodal method required twice the CPU time required by the weighted-difference method.

Contour plots of the TORT-calculated total neutron flux superimposed on drawings of the calculational geometry are shown in Fig. 5. Plots are shown for all exterior plane surfaces except for that at $Z=Z \max$. As shown in Fig. 5, ray effects are very pronounced in the first leg. In the DOT3.5 calculations, a 124-direction quadrature set biased in the axial direction was used and ray effects were not observed. In this 3-D calculation, the 60-direction quadrature was rather coarse and was not biased enough in the direction of neutron streaming. Therefore, ray effects were observed. Since the only reflected boundary condition was at the bottom boundary, a quadrature set biased along both legs of the chaseway could have been used. But, due to the higher calculational cost that would result, no consideration was given to increasing the number of angles in the quadrature set. 
Table 4. Convergence Statistics (Numbers of Iterations and Flux Errors) by Group for the TORT and ENSEMBLE Calculations.

\begin{tabular}{|c|c|c|c|c|c|c|c|}
\hline \multirow{3}{*}{ Group } & \multicolumn{4}{|c|}{ TORT } & \multirow{2}{*}{\multicolumn{3}{|c|}{$\frac{\text { ENSEMBLE }}{\text { Weighted }}$}} \\
\hline & \multicolumn{2}{|c|}{ Nodal } & \multicolumn{2}{|c|}{ Weighted } & & & \\
\hline & Iter. & Err.\% & Iter. & Err.\% & Iter. & Err\% & Acceleration ${ }^{* 1}$ \\
\hline 1 & 18 & 0.78 & 18 & 0.64 & 12 & 0.62 & ON \\
\hline 2 & 16 & 0.84 & 17 & 0.90 & 10 & 0.65 & ON \\
\hline 3 & 20 & 0.96 & 20 & 0.92 & 9 & 0.57 & ON \\
\hline 4 & 13 & 0.96 & 14 & 0.88 & 9 & 0.89 & ON \\
\hline 5 & 13 & 0.88 & 17 & 0.63 & 12 & 0.71 & ON \\
\hline 6 & 9 & 0.95 & 10 & 0.91 & 10 & 0.84 & ON \\
\hline 7 & 11 & 0.90 & 13 & 0.71 & 18 & 0.95 & ON \\
\hline 8 & 11 & 0.70 & 12 & 0.89 & 14 & 0.97 & ON \\
\hline 9 & 16 & 0.90 & 17 & 0.74 & 25 & 0.89 & ON \\
\hline 10 & 14 & 0.99 & 14 & 0.93 & 29 & 1.00 & ON \\
\hline 11 & 16 & 0.85 & 16 & 0.86 & 19 & 0.91 & ON \\
\hline 12 & 21 & 0.99 & 21 & 0.92 & 56 & 0.81 & ON - OFF $(51)^{\circ 2}$ \\
\hline 13 & 8 & 0.92 & 10 & 0.77 & 29 & 0.73 & ON \\
\hline 14 & 12 & 0.98 & 13 & 0.93 & 16 & 0.93 & ON \\
\hline 15 & 12 & 0.99 & 14 & 0.97 & 15 & 0.60 & ON \\
\hline 16 & 15 & 0.88 & 16 & 0.72 & 21 & 0.54 & ON \\
\hline 17 & 15 & 0.87 & 18 & 0.95 & 23 & 0.95 & ON - OFF (18) \\
\hline 18 & 14 & 1.00 & 17 & 0.80 & 35 & 0.88 & ON \\
\hline 19 & 14 & 1.00 & 18 & 0.71 & 23 & 0.69 & ON - OFF (20) \\
\hline 20 & 12 & 0.86 & 18 & 0.80 & 18 & 1.00 & ON \\
\hline 21 & 50 & 3.35 & 30 & 6.13 & 70 & 1.45 & OFF \\
\hline $\mathrm{T}$ & 330 & & 343 & & 473 & & \\
\hline
\end{tabular}


15

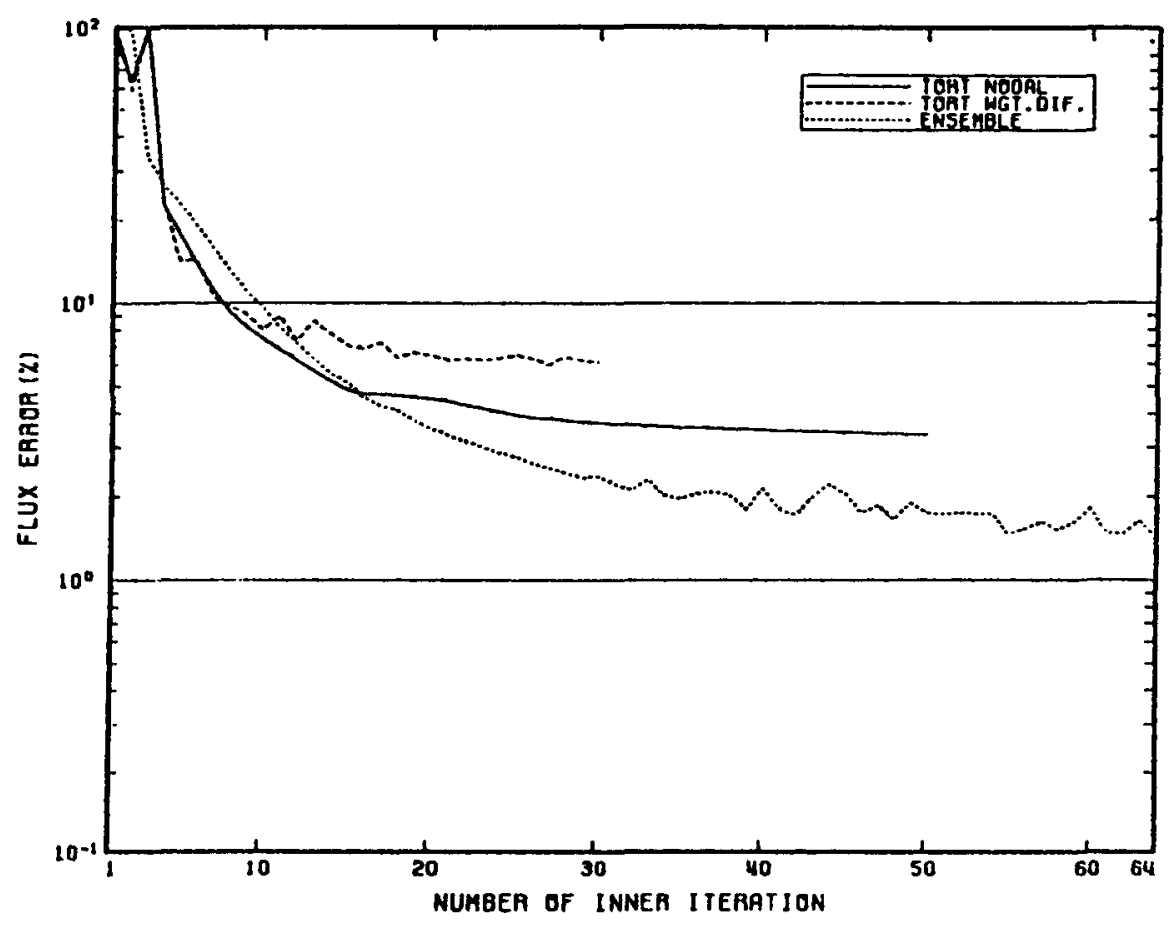

Fig. 4. Convergence of the Thermal-Neutron Group as a Function of the Number of Inner Iterations. 


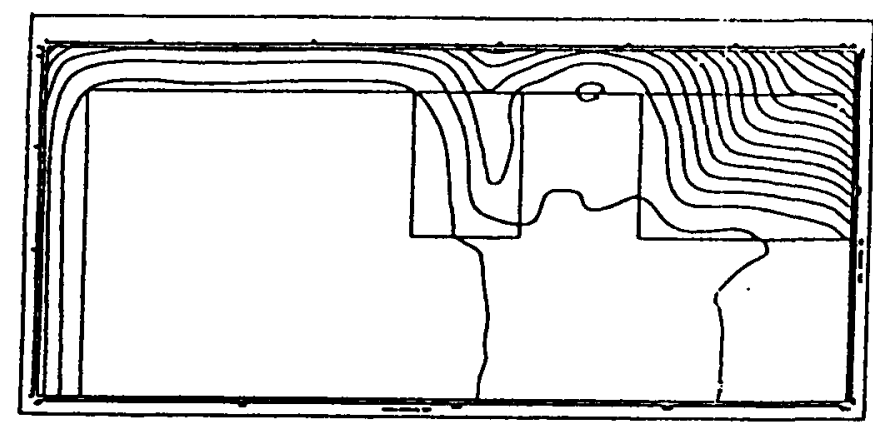

$X-Z$ Plane, $Y=Y \max$
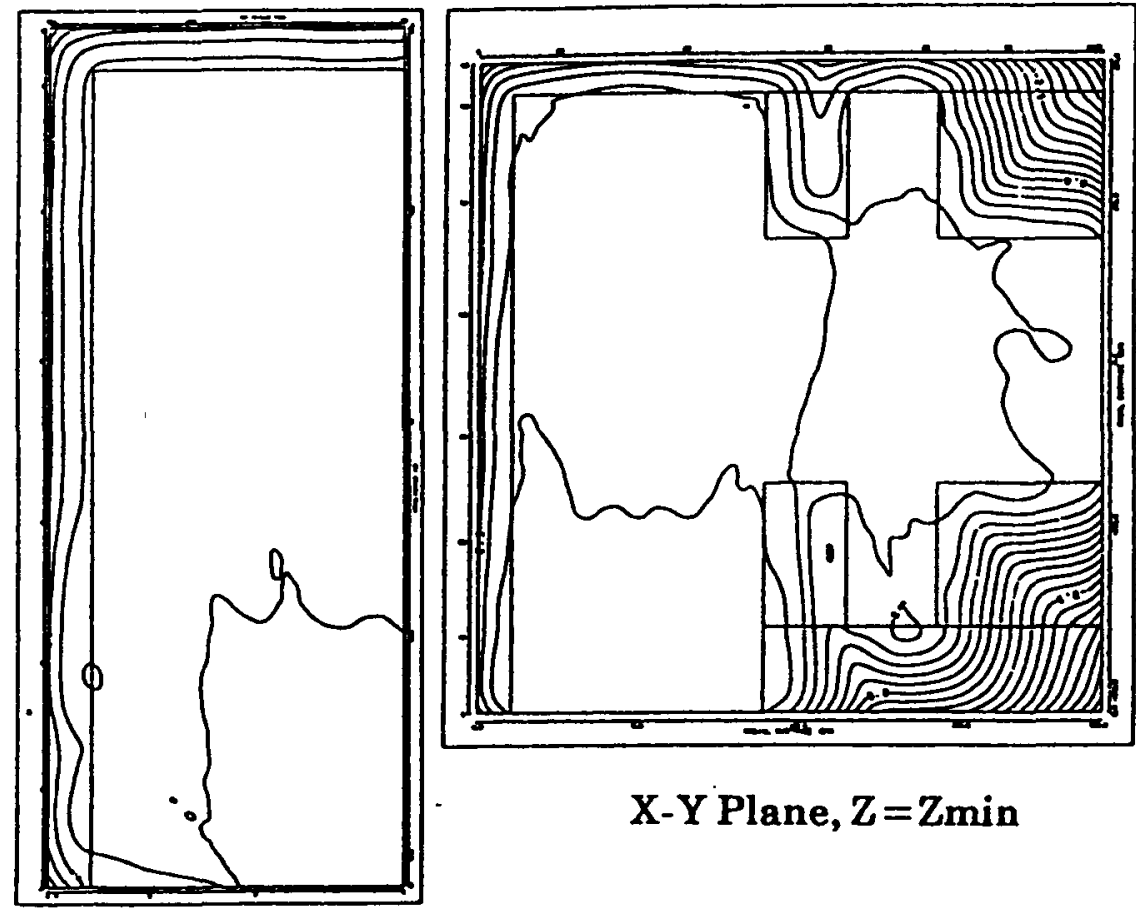

$\mathrm{X}-\mathrm{Y}$ Plane, $\mathrm{Z}=\mathrm{Zmin}$

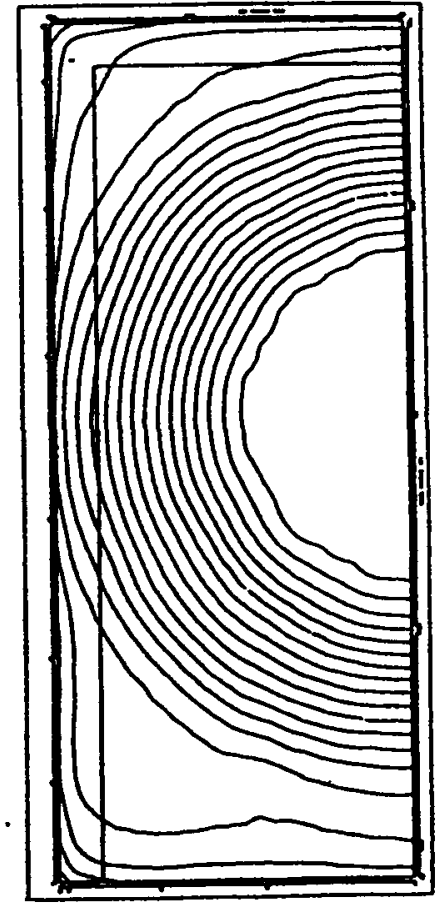

$\mathrm{Y}-\mathrm{Z}$ Plane, $\mathrm{X}=\mathrm{X} \min$

Y-Z Plane, $X=X \max$

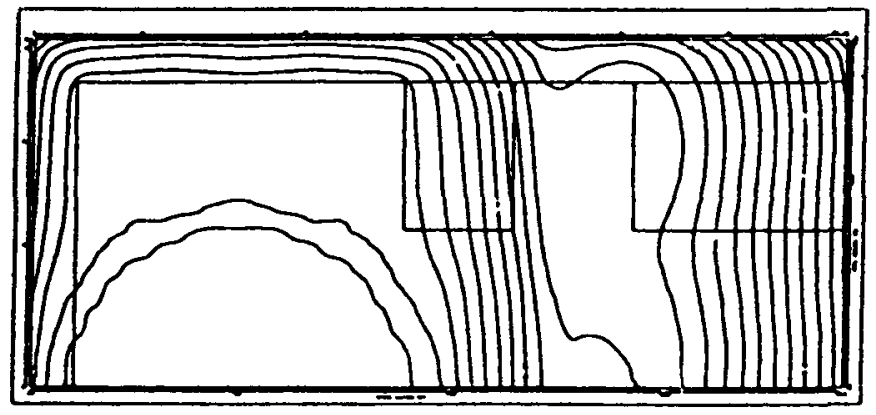

$\mathrm{X}-\mathrm{Z}$ Plane, $\mathrm{Y}=\mathrm{Y} \min$

Fig. 5. TORT-Calculated Total-Neutron Flux Distributions at the External Surfaces of the Geometry Model for the CRBR Prototypic Coolant Pipe Chaseway Neutron Streaming Experiment. 
One may note also from the $X-Z$ plane plot at $Y=Y \min$ and the $Y-Z$ plane plot at $X=X \max$ of Fig. 5 that the contours around the choke openings are nearly circular. This attests to the adequacy of the modeling of the circular opening in the chokes with a polygon.

Neutron spectra on the reactor neutron beam centerline at the entrance (choke no. 1) and exit (choke no. 3) of the chaseway calculational configuration are shown in Fig. 6. The spectrum at the exit is considerably softer than that at the entrance. The greatest changes in flux fractions appear to be in the energy range below $100 \mathrm{eV}$. The low-energy flux buildup is due to neutron scattering from the chokes and the concrete walls of the chaseway.

Total-, fast-, epithermal-, and thermal-neutron flux distributions along the centerline of the first and second legs of the chaseway, calculated with TORT using the weighted-difference method, are shown in Figs. 7-1 through 7-4. In the figures, the dashed and solid lines are for traverses along the centerline of the first and second legs, respectively. Note that the sharp drops in the curves occur in the concrete walls at the ends of the chaseway legs. The total-neutron flux along the first leg is attenuated two orders of magnitude. Also, there is a pronounced dip in the total-neutron flux distribution for the second leg as it crosses the centerline of the first leg. This is due to ray effects resulting from the use of a coarse quadrature to calculate neutron fluxes in the large void regions of the chaseway.

TORT- and DOT3.5-calculated total-neutron flux distributions along the centerline of the chaseway are compared in Fig. 8-1 for the first leg and Fig. 8-2 for the second leg. First, it is seen from Fig. 8-1 that the calculated flux distributions agree reasonably well in the first leg of the chaseway. Second, total-neutron fluxes calculated with TORT using the weighted-difference and nodal methods agree very well. Total-neutron fluxes calculated using the nodal method were 5 to $10 \%$ higher than those calculated using the weighted-difference method. Third, it is seen, particularly in Fig. 8-2, that ray effects have a significant influence on the first-leg flux at the opening to the second leg. In Fig. 8-1, the dip in the TORT-calculated flux at the opening to the second leg doesn't seem as pronounced as it is in Fig. 8-2. Fourth, ray effects for TORT calculations using the weighted-difference method are not the same as those for TORT calculations using the nodal method. Fifth, TORT fluxes at the bend in the chaseway are somewhat lower than the doubly-defined DOT3.5 fluxes. However, the TORT fluxes are substantially higher in the second leg of the chaseway.

Generally, in calculations using the nodal method, the spatial mesh intervals can be coarser than those for calculations using the weighted-difference method. However, there was little difference between results for the two methods in the present TORT calculations because the spatial mesh intervals in these calculations were fine enough. Therefore, it was not confirmed that the nodal method was advantageous for these calculations. Still, gaining calculational experience in selecting the method to use in TORT is important, considering the fact that the nodal method in general requires more calculational time than does the weighted-difference method. 


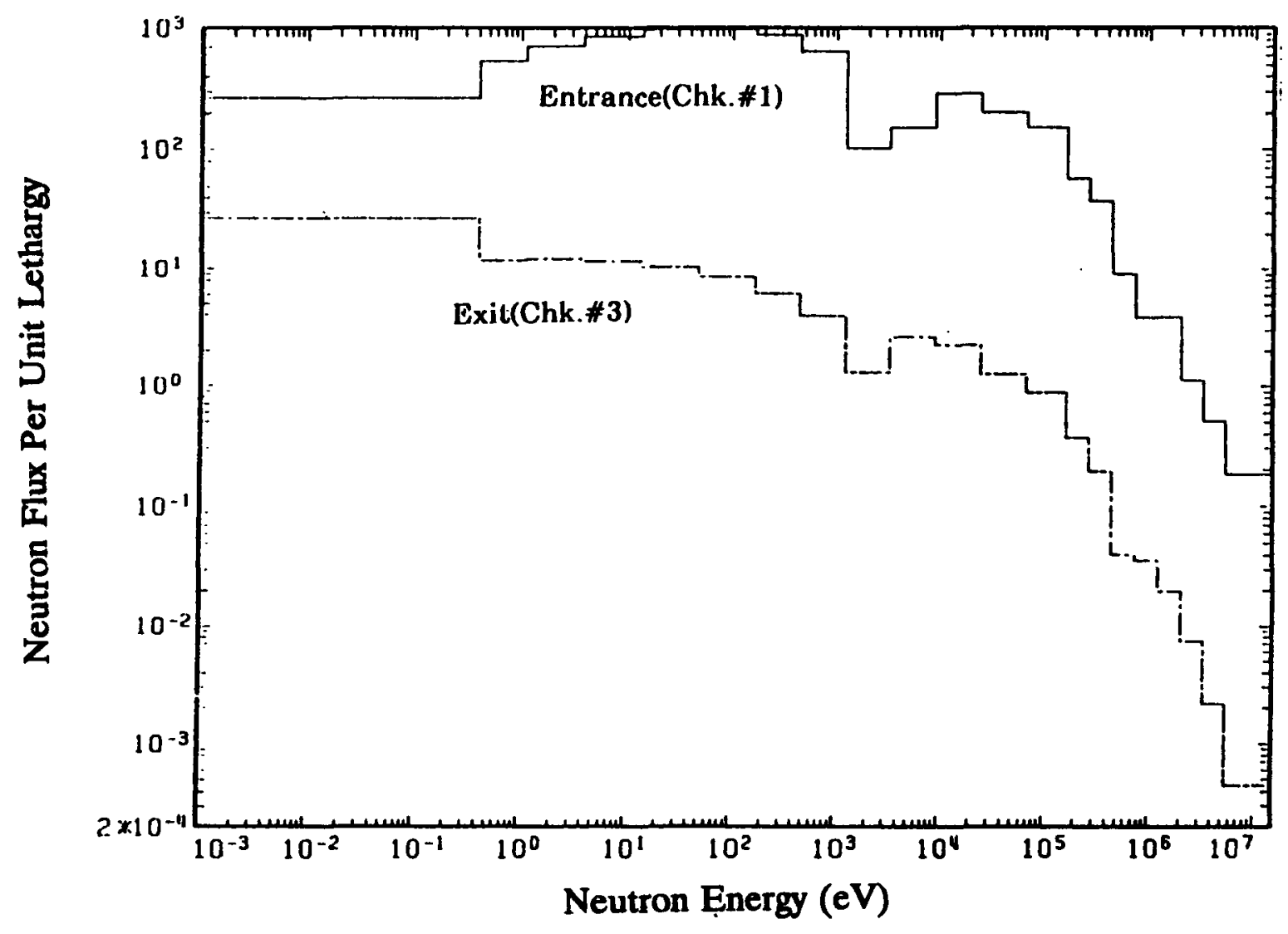

Fig. 6. TORT-Calculated Neutron Energy Spectra on the Chaseway Centerline at the Entrance (Choke no.1) and Exit (Choke no. 3) of the First Bend in the Chaseway. 


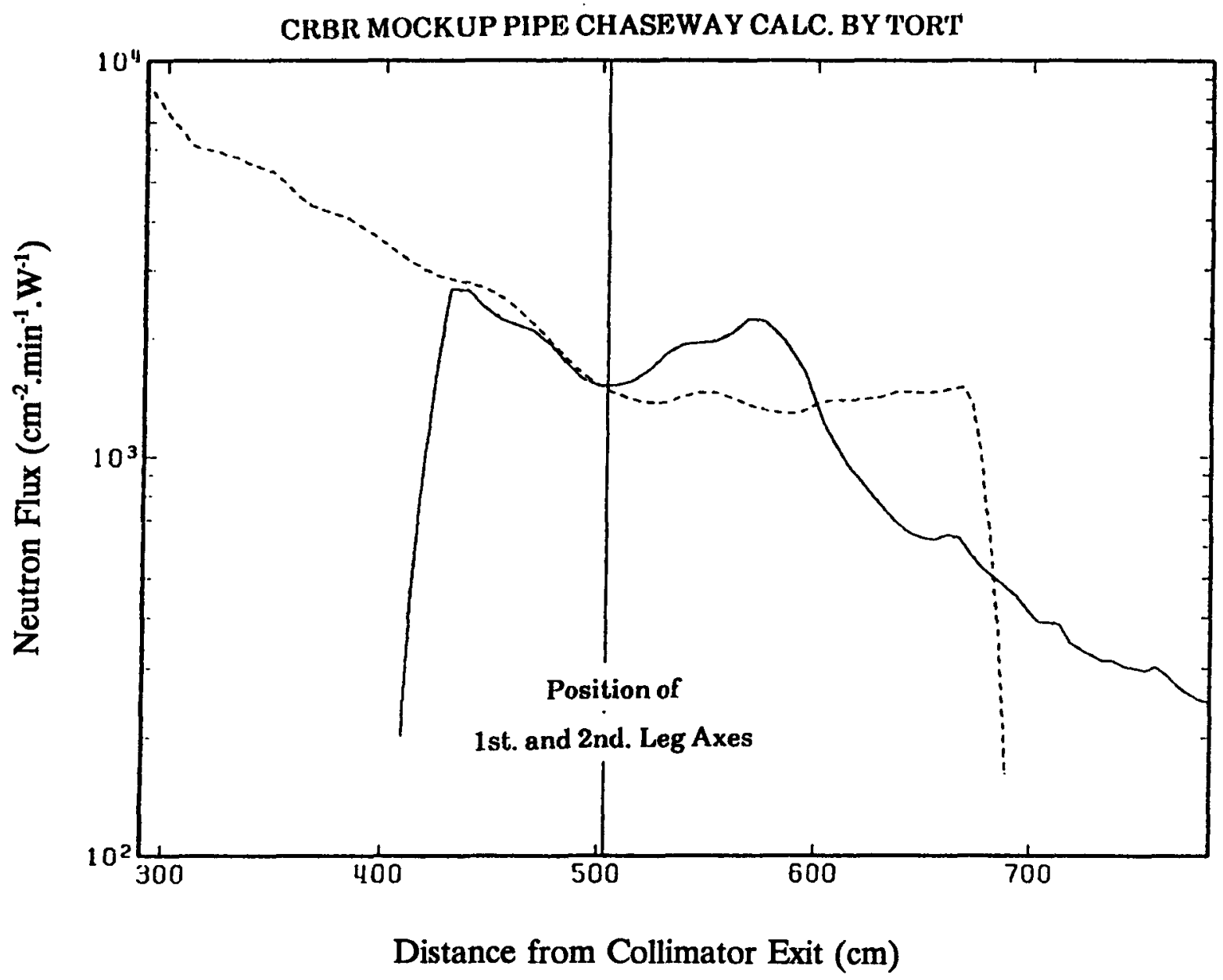

Fig. 7-1. TORT-Calculated Total-Neutron Flux Distribution Along the Centerline of the Chaseway. 


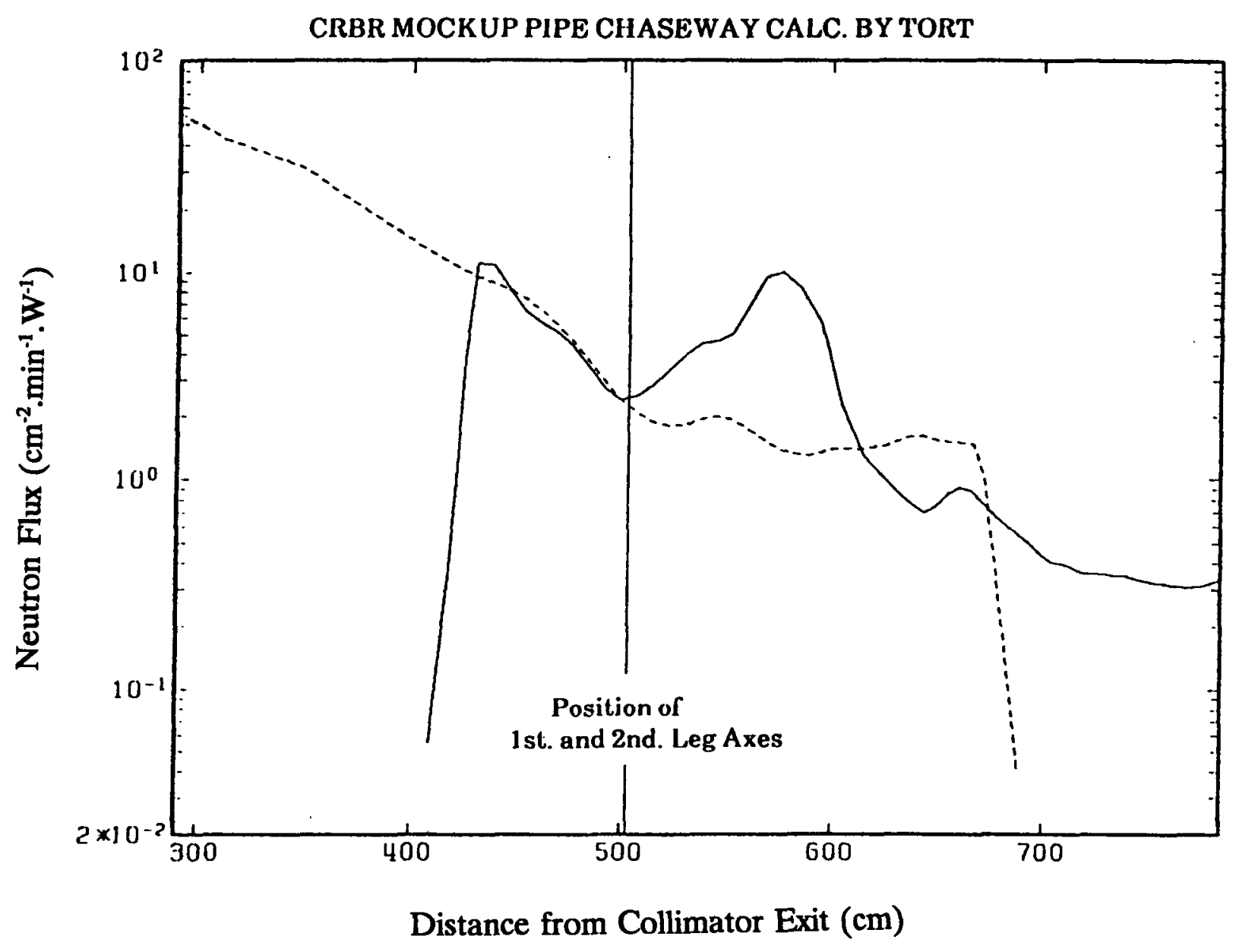

Fig. 7-2. TORT-Calculated Fast-Neutron Flux (E > $166 \mathrm{keV}$ ) Distribution Along the Centerline of the Chaseway. 


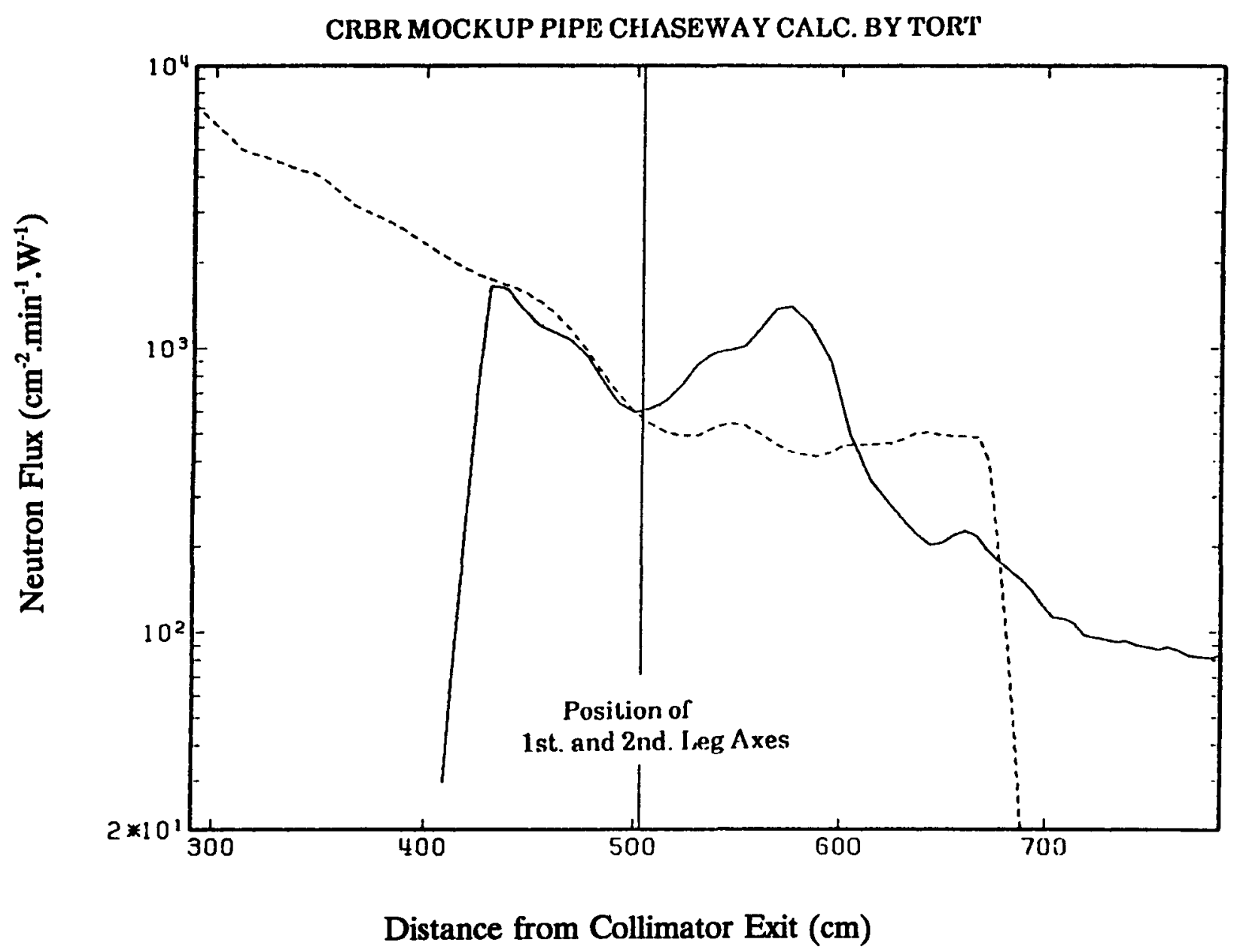

Fig. 7-3. TORT-Calculated Epithermal-Neutron Flux $(0.414 \mathrm{eV}<\mathrm{E}<166 \mathrm{keV})$ Distribution Along the Centerline of the Chaseway. 


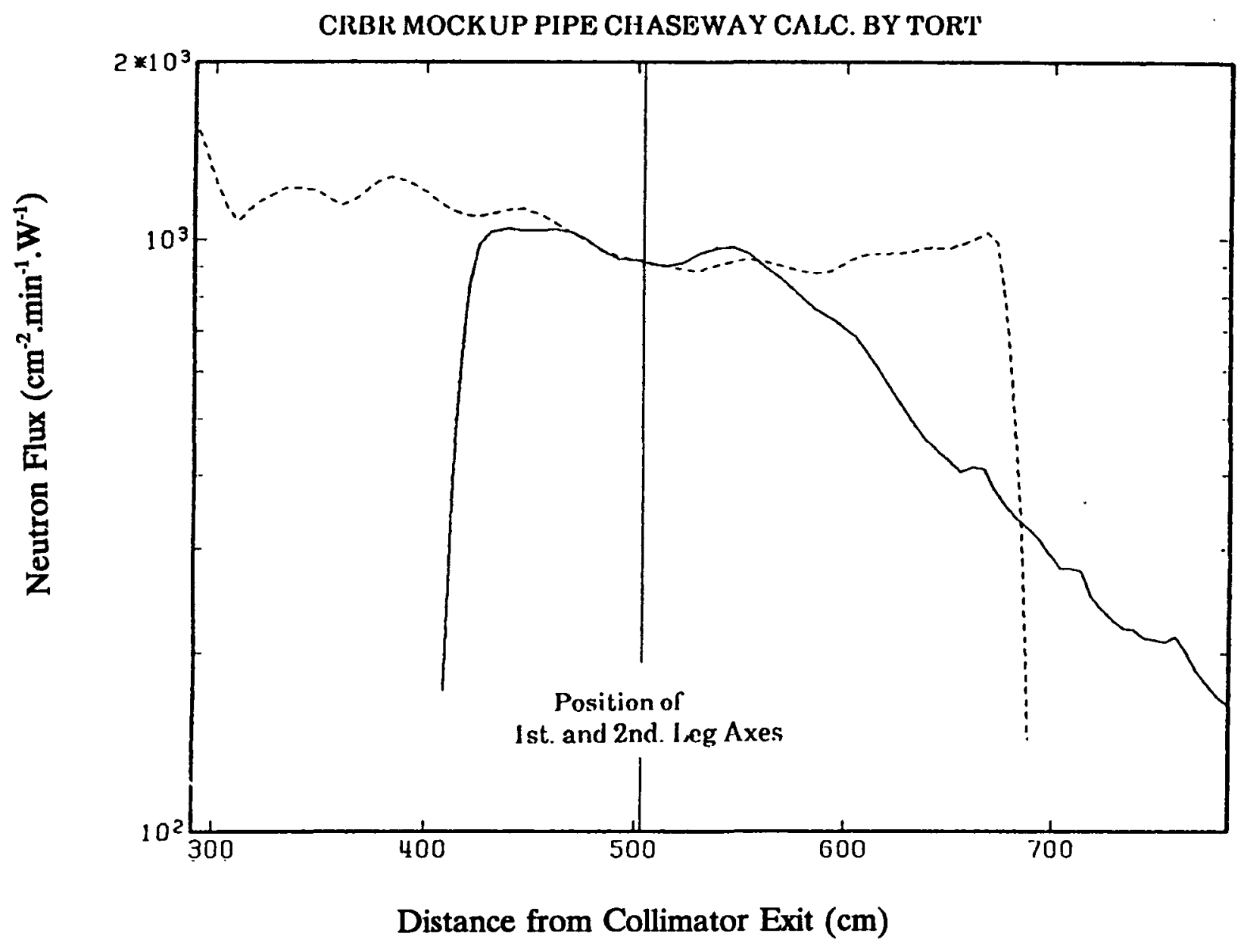

Fig. 7-4. TORT-Calculated Thermal-Neutron Flux $(\mathrm{E}<0.414 \mathrm{eV})$ Distribution Along the Centerline of the Chaseway. 


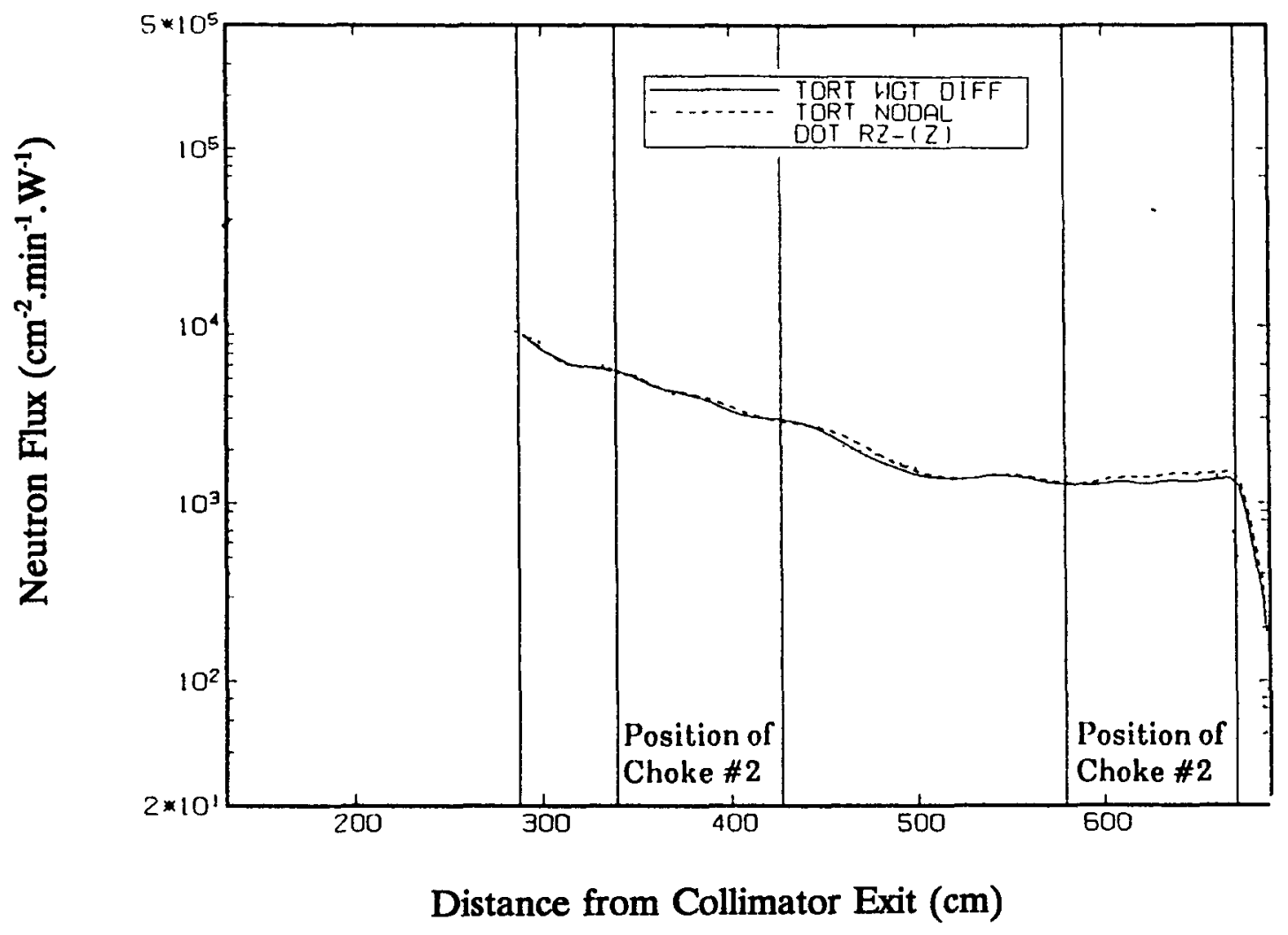

Fig. 8-1. Comparison of Calculated Total-Neutron Flux Distributions Along the Centerline of the First Leg of the Chaseway. 


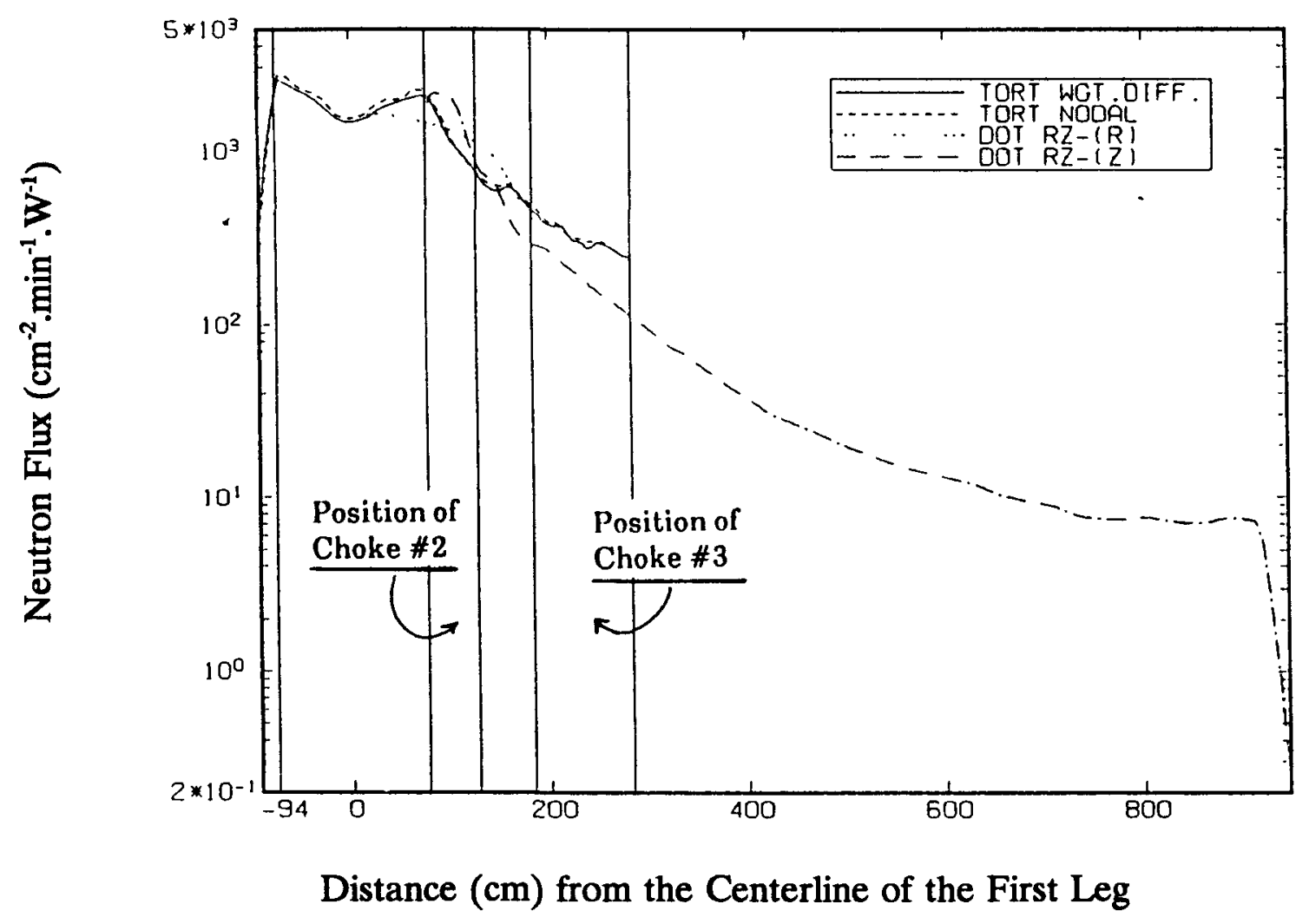

Fig. 8-2. Comparison of Calculated Total-Neutron Flux Distributions Along the Centerline of the Second Leg of the Chaseway. 


\section{MORSE-CALCULATED RESULTS}

MORSE calculations were performed using the same boundary conditions used in the TORT and ENSEMBLE calculations (see Sect. 4). The DOT3.5 internal boundary flux file, used as a source in the 3-D discrete ordinates calculations, was processed with the DOMINO ${ }^{14}$ code to produce the source distributions needed by MORSE. The MORSE calculations were biased with path-length stretching, and an energy cutoff was set at the thermal-neutron group boundary. For the path-length stretching, the value of DIREC was set to $W$ in the first leg and $U$ in the second leg, based on the ENSEMBLE labelings for the geometry in Fig. 3. Selected MORSE results are presented in Sect. 6 and detailed results are found in Appendix II. 


\section{COMPARISONS OF CALCULATED AND MEASURED DATA}

Measurement locations of interest that are within the TORT and ENSEMBLE geometry models are shown in Fig. 9. Measured data along the centerlines of the first and second legs of the chaseway are compared with calculated results at those locations and a few locations outside the Fig. 9 geometry model for the DOT3.5 and MORSE calculations. The comparisons of the measured results in the first leg of the chaseway with TORT- and DOT3.5-calculated results are shown in Table 5-1, Figs. 10, and Figs. 11. MORSE C/E values are also included in Tables 5-2 through 5-5 and are plotted in Figs. 11-2 and 11-3.

On comparing the calculated and measured bare Bonner ball count rates along the centerline of the first leg of the chaseway, one finds that the TORT C/E values are improved over the DOT3.5 values as shown in Figs. 10-1 and 11-1. For these measurements, the bare Bonner ball count rate is due mainly to thermal neutrons. There appear to be at least two reasons for the improvement in the calculated results. First, in the TORT calculations, thermal neutrons were produced by the scattering of fast and epithermal neutrons in the concrete surrounding the chaseway. This resulted in widely distributed thermal-neutron sources within the first leg, and ray effects were scarce in the thermal-neutron group. Second, the approximation of the second-leg opening in the DOT3.5 first-leg R-Z geometry (as discussed in Sect. 2), caused DOT3.5 to underestimate the thermal-neutron fluxes and thus the bare Bonner ball count rate. The TORT geometry in the vicinity of the second leg, unlike the DOT3.5 geometry, has three solid concrete walls opposite the opening. Consequently, TORT's localized scattering source strength should be greater than DOT3.5's.

On the other hand, the TORT-calculated responses for the other Bonner balls, which measure mostly epithermal- and fast-neutron flux, were underestimated near the opening of the second leg. Generally, discrete ordinates codes suffer from the characteristic problem of ray effects. In order to reduce or eliminate ray effects, one may increase the number of angles in the quadrature set in the direction of neutron streaming, but this could require much more computer time. The $\mathrm{C} / \mathrm{E}$ values for the 2 - and 3 -inch Bonner ball count rates along the centerline of the first leg of the chaseway are shown in Figs. 11-2 and 11-3. These figures reveal that $C / E$ values for the TORT results decrease sharply about $200 \mathrm{~cm}$ from the sodium tank. The decrease is greater for the 3-inch Bonner ball count rate due to the greater fast-neutron flux contribution to the count rate.

C/E values for MORSE-calculated results are also shown in Figs. 11-2 and 11-3 (The bare Bonner ball count rate was not calculated). The MORSE C/E values generally lie between the DOT3.5 and TORT C/E values. The MORSE C/E values are low near the sodium tank due to the effects of path-length stretching at the source surface (choke no. 1). Like the TORT C/E values, the MORSE C/E values also decrease sharply about 200 cm from the sodium tank.

TORT- DOT3.5-, and ENSEMBLE-calculated Bonner ball count rates along the centerline of the second leg of the chaseway are compared with measured data in Figs. 12, Figs. 13, and Tables 6. MORSE C/E values are also included in Tables 6-2 through 6-5 and are plotted in Figs 13-2 and 13-3. The TORT geometry included only a portion of 


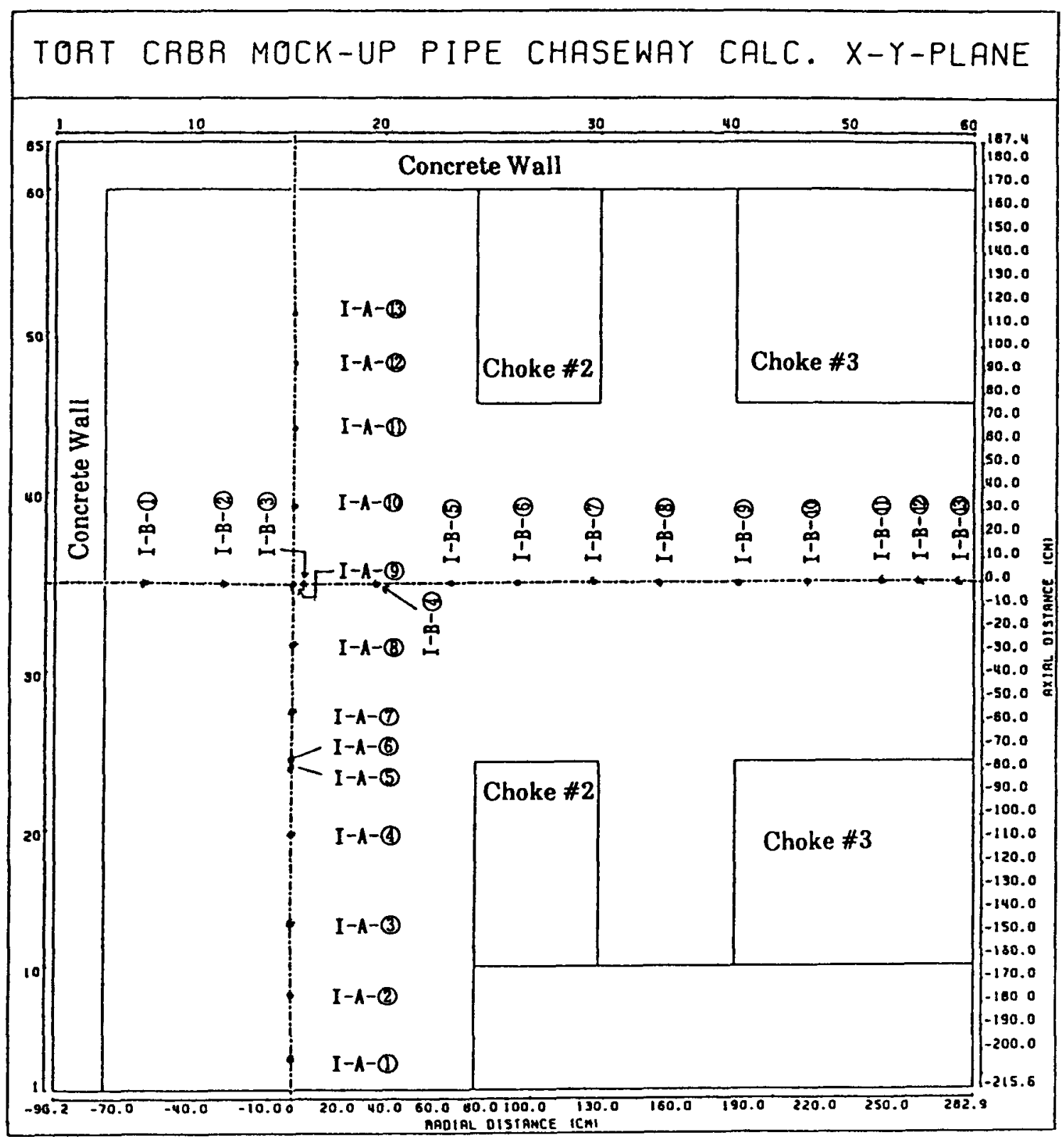

Fig. 9. Measurement Locations Within the Calculational Geometry for the Region of the CRBR Prototypic Coolant Pipe Chaseway Experimental Mockup That Was Analyzed With TORT and ENSEMBLE. 
Table 5-1. Comparison of Calculated and Measured Bare Bonner Ball Count Rates

Along the Centerline of the First Leg of the Chaseway.

\begin{tabular}{|c|c|c|c|c|c|c|c|}
\hline \multirow[b]{2}{*}{$\begin{array}{c}\text { Position } \\
\text { No. }\end{array}$} & \multirow[b]{2}{*}{$\begin{array}{l}\text { Distance from } \\
\text { Na Tank } \\
\text { (cm) }\end{array}$} & \multirow[b]{2}{*}{$\begin{array}{l}\text { Measurement } \\
\quad(\mathrm{cps} / \mathrm{W})\end{array}$} & \multicolumn{5}{|c|}{$\mathrm{C} / \mathrm{E}$} \\
\hline & & & $\begin{array}{c}\text { TORT } \\
\text { (weighted) }\end{array}$ & $\begin{array}{l}\text { TORT } \\
\text { (nodal) }\end{array}$ & $\begin{array}{c}\text { ENSEM- } \\
\text { BLE }\end{array}$ & $\begin{array}{c}\text { DOT } \\
\text { (1st. leg, } \\
\text { on axis) }\end{array}$ & MORSE \\
\hline I-A-1 & 104.46 & $4.59 \mathrm{E}+01$ & 0.65 & 0.64 & 0.69 & 0.75 & $-1)$ \\
\hline I-A-2 & 134.94 & $3.99 \mathrm{E}+01$ & 0.68 & 0.67 & 0.69 & 0.69 & - \\
\hline I-A-3 & 165.42 & $3.53 E+01$ & 0.70 & 0.69 & 0.70 & 0.69 & - \\
\hline I-A-4 & 195.90 & $3.15 \mathrm{E}+01$ & 0.79 & 0.79 & 0.71 & 0.63 & - \\
\hline I-A-5 & 218.92 & $2.89 \mathrm{E}+01$ & 0.77 & 0.75 & 0.71 & 0.58 & - \\
\hline I-A-6 & 220.66 & $2.85 E+01$ & 0.78 & 0.76 & 0.72 & 0.59 & - \\
\hline 1-A-7 & 249.71 & $2.61 \mathrm{E}+01$ & 0.82 & 0.81 & 0.71 & 0.57 & - \\
\hline I-A-8 & 280.19 & $2.38 \mathrm{E}+01$ & 0.75 & 0.77 & 0.70 & 0.52 & - \\
\hline I-A-9 & 310.67 & $2.22 \mathrm{E}+01$ & 0.73 & 0.73 & 0.71 & 0.45 & - \\
\hline I-A-10 & 341.15 & $2.16 \mathrm{E}+01$ & 0.76 & 0.74 & 0.71 & 0.50 & - \\
\hline I-A-11 & 371.63 & $2.30 \mathrm{E}+01$ & 0.70 & 0.70 & 0.66 & 0.48 & - \\
\hline I-A-12 & 402.11 & $2.16 \mathrm{E}+01$ & 0.74 & 0.75 & 0.70 & 0.53 & - \\
\hline I-A-13 & 425.61 & $2.20 \mathrm{E}+01$ & 0.73 & 0.76 & 0.69 & 0.57 & - \\
\hline
\end{tabular}

1) Not estimated. (Thermal neutron was not included in MORSE calculation.) 

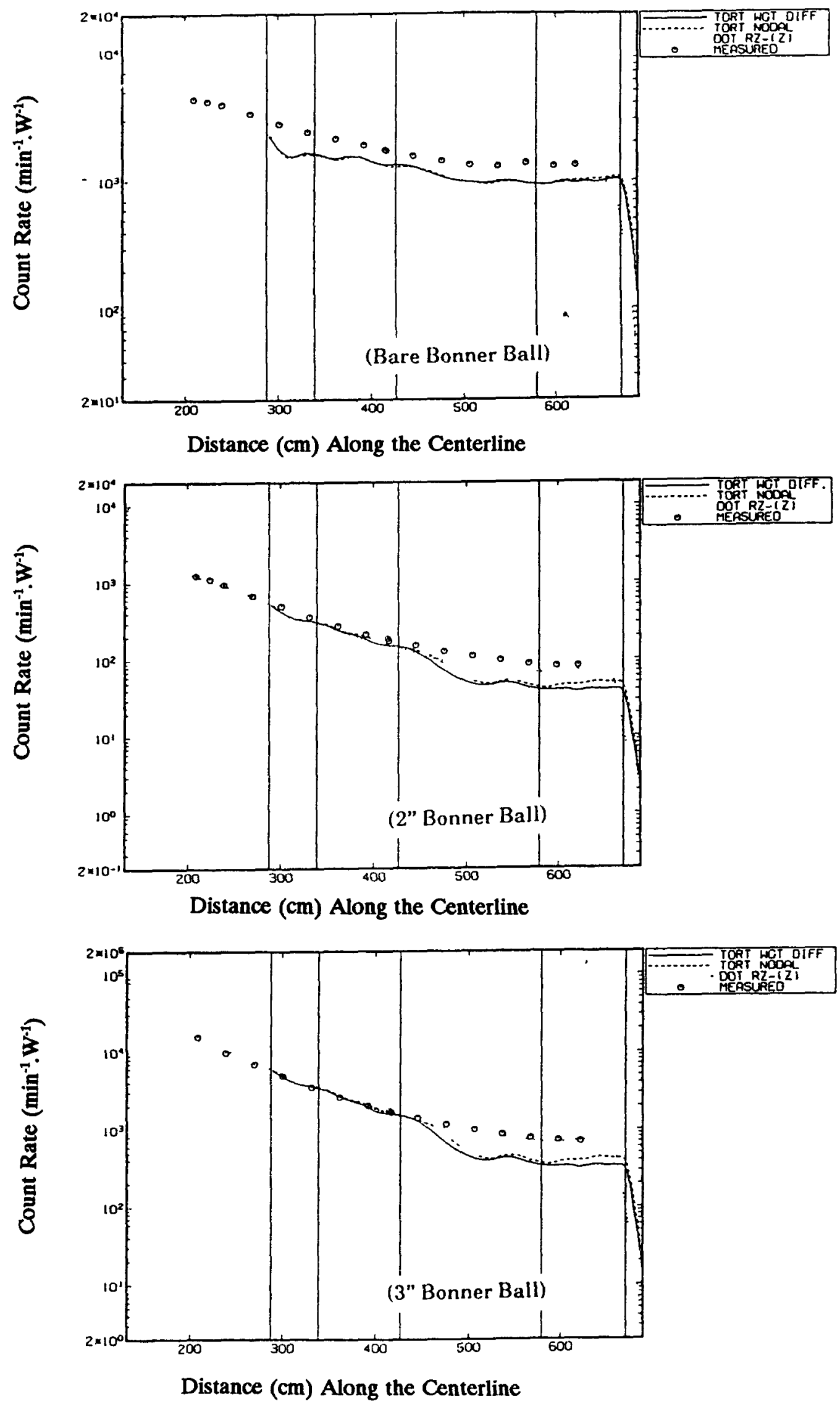

Fig. 10-1. Comparison of Calculated and Measured Bare, 2-inch, and 3-inch Bonner Ball Count Rates $\left(\mathrm{min}^{-1} . \mathrm{W}^{-1}\right)$ Along the First-Leg Axis of the Chaseway. 

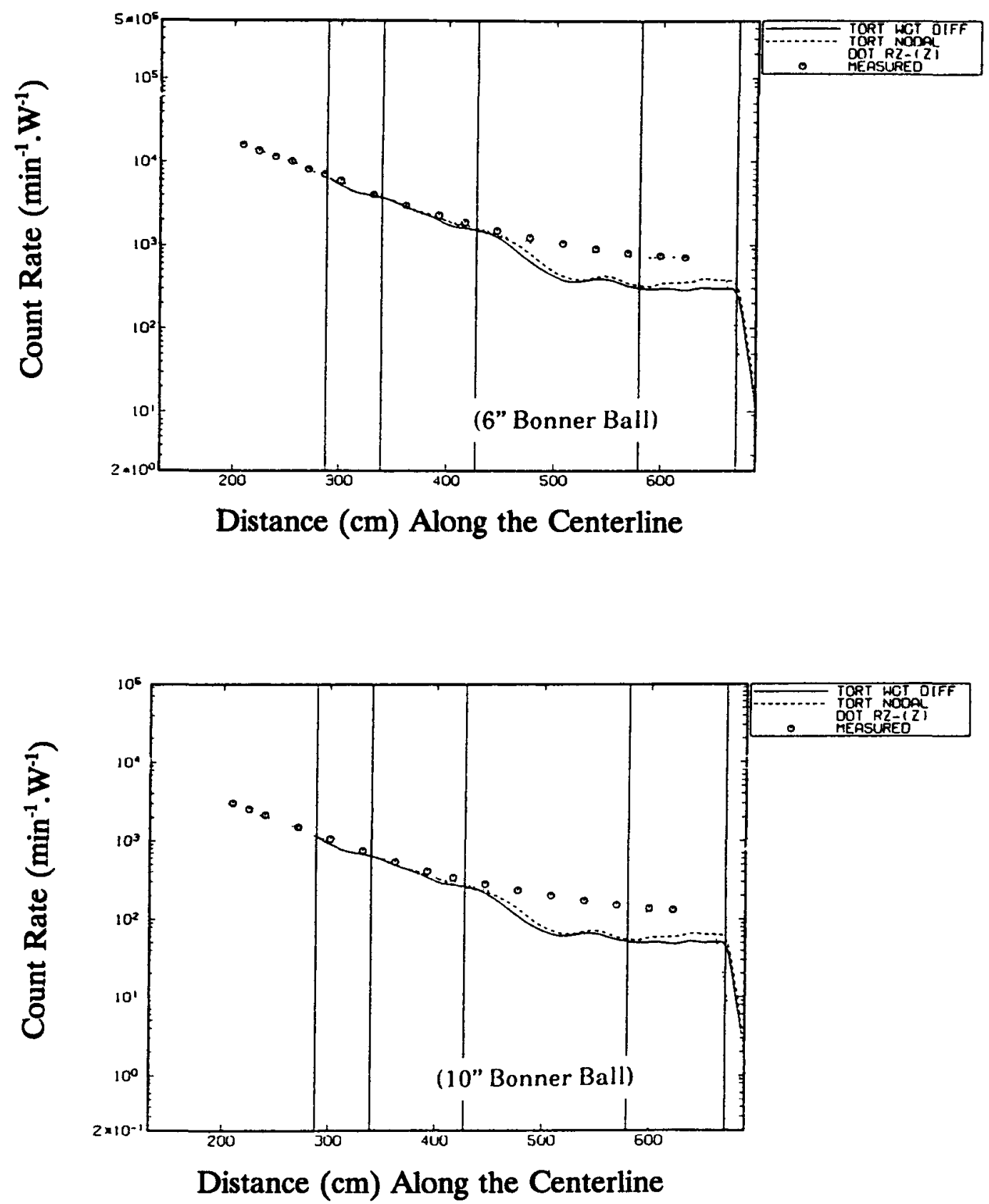

Fig. 10-2. Comparison of Calculated and Measured 6-inch and 10-inch Bonner Ball Count Rates $\left(\mathrm{min}^{-1} . \mathrm{W}^{-1}\right)$ Along the Centerline of the First Leg of the Chaseway. 


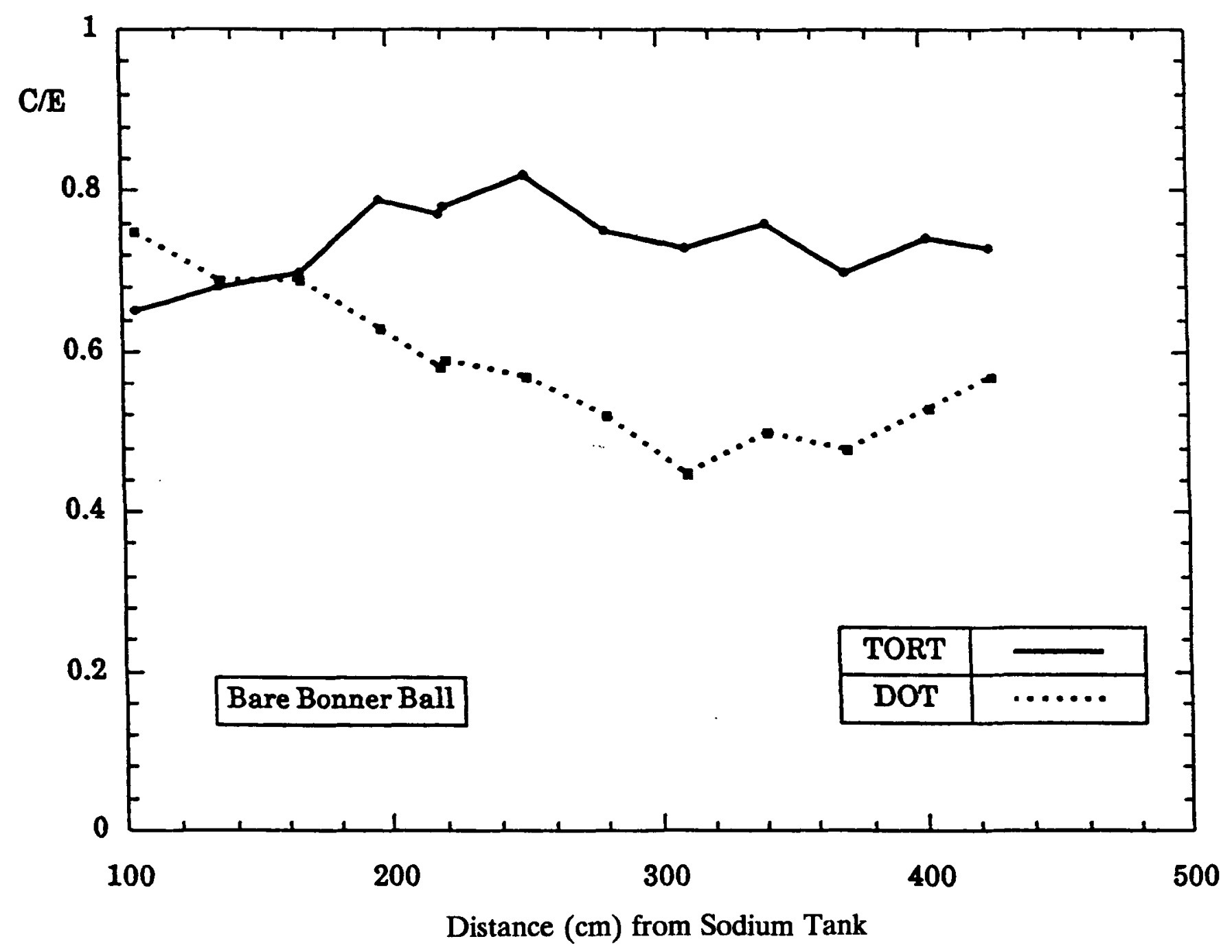

Fig. 11-1. C/E Values for the Bare Bonner Ball Count Rate Along the Centerline of the First Leg of the Chaseway. 


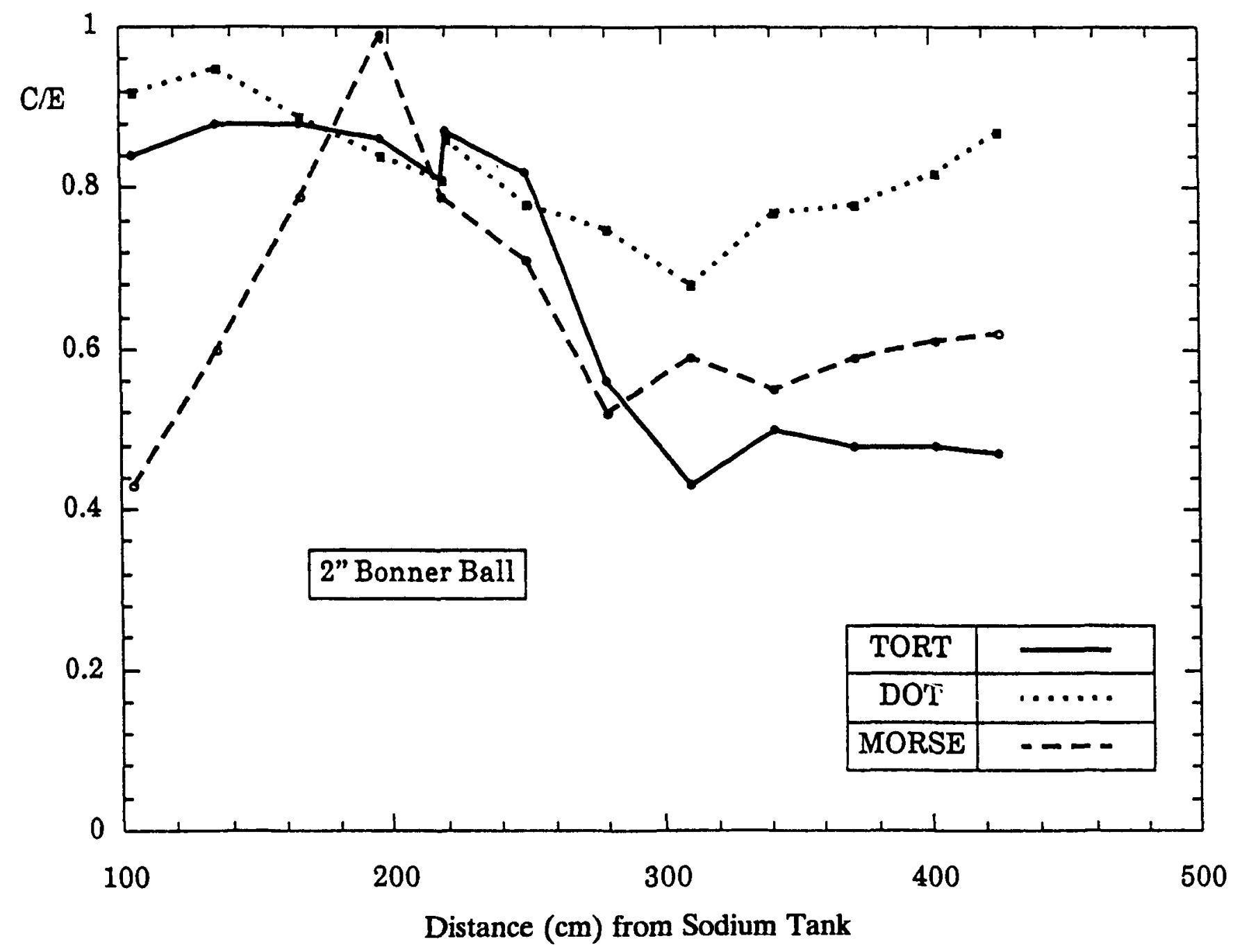

Fig. 11-2. C/E Values for the 2-inch Bonner Ball Count Rate Along the Centerline of the First Leg of the Chaseway. 


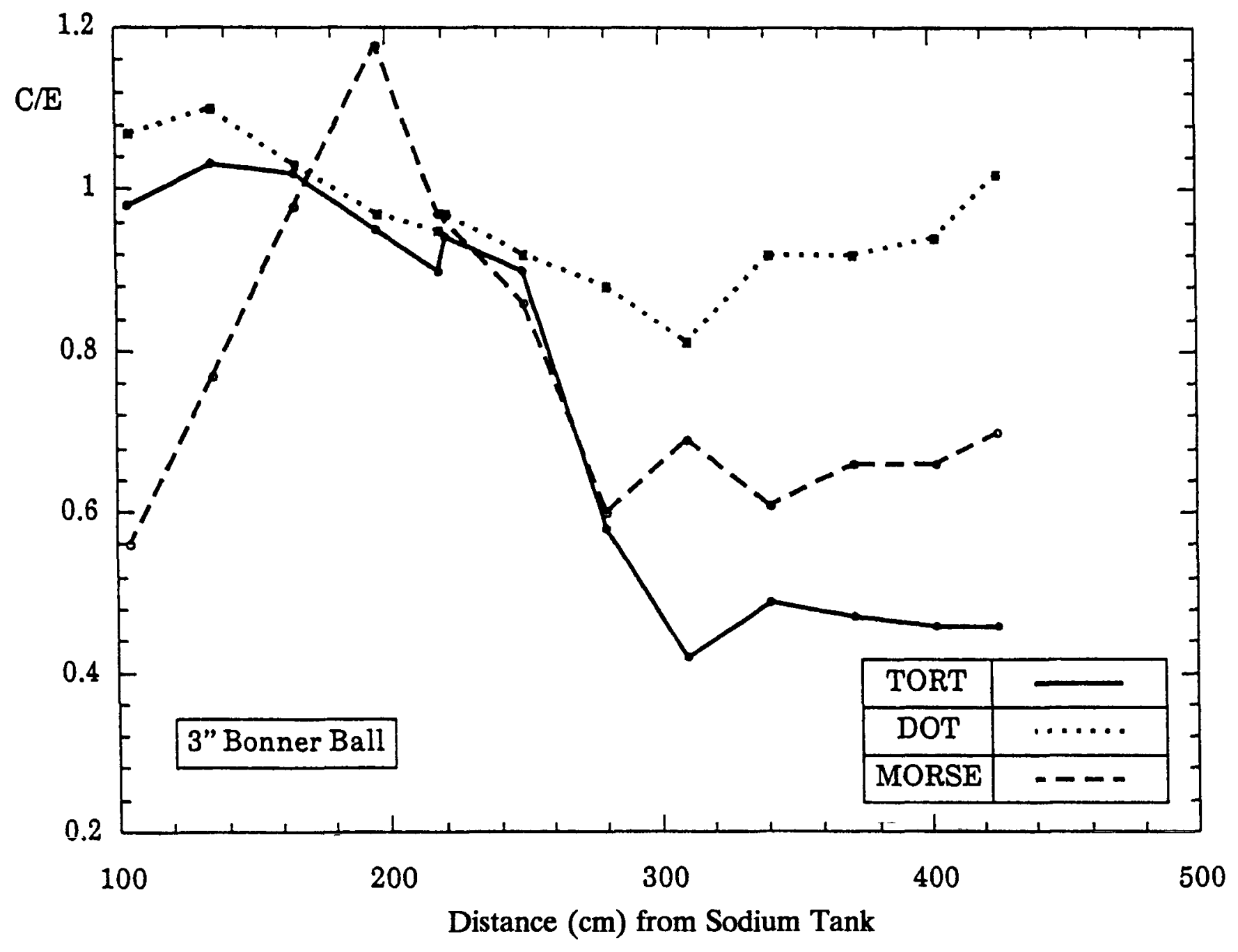

$\underset{w}{w}$

Fig. 11-3. C/E Values for the 3-inch Bonner Ball Count Rate Along the Centerline of the First Leg of the Chaseway. 
34
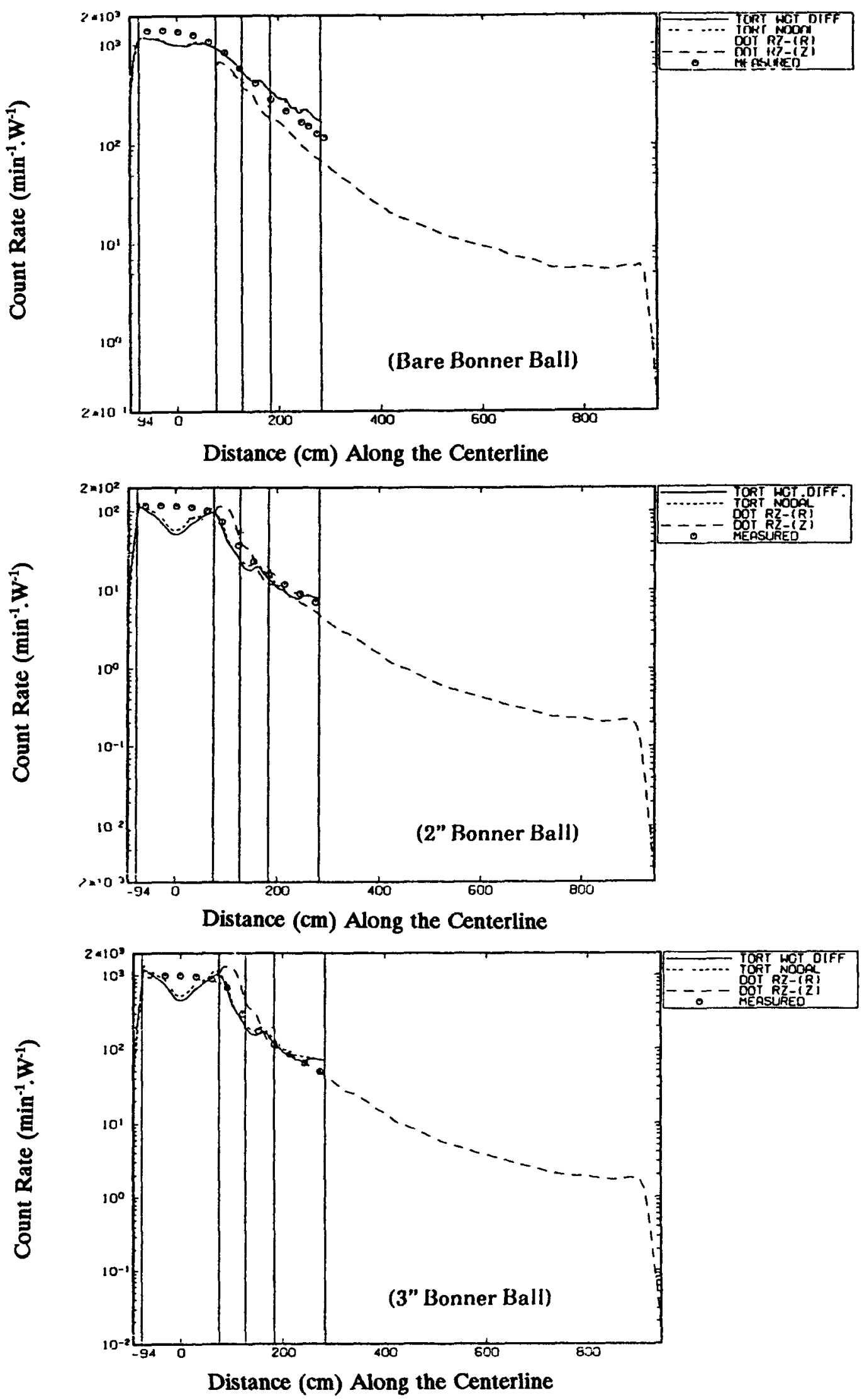

Fig. 12-1. Comparison of Calculated and Measured Bare, 2-inch, and 3-inch Bonner Ball Count Rates $\left(\mathrm{min}^{-1} . \mathrm{W}^{-1}\right)$ Along the Centerline of the Second Leg of the Chaseway. 

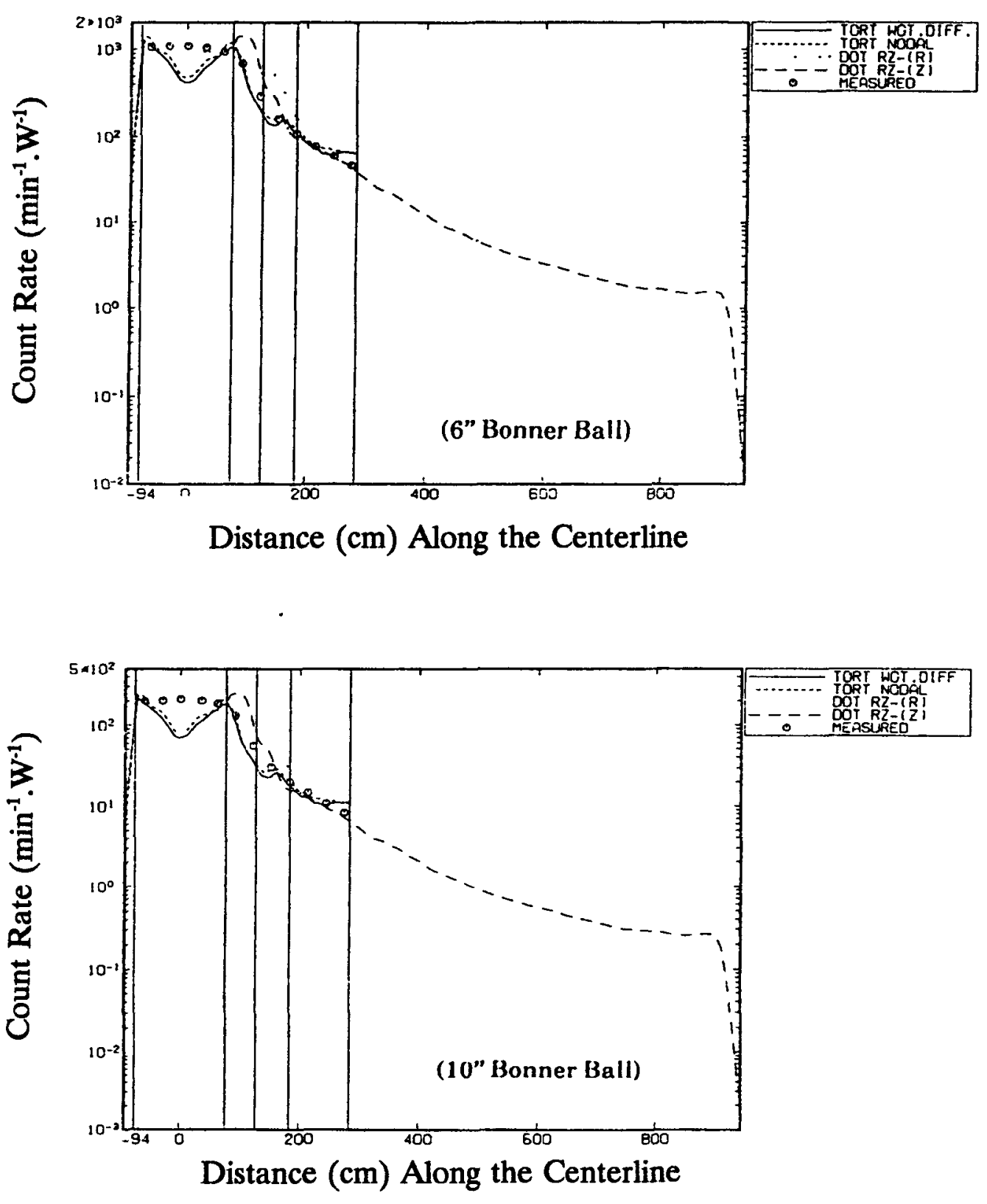

Fig. 12-2. Comparison of Calculated and Measured 6-inch and 10-inch Bonner Ball Count Rates $\left(\mathrm{min}^{-1} \cdot \mathbf{W}^{-1}\right)$ Along the Centerline of the Second Leg of the Chaseway. 


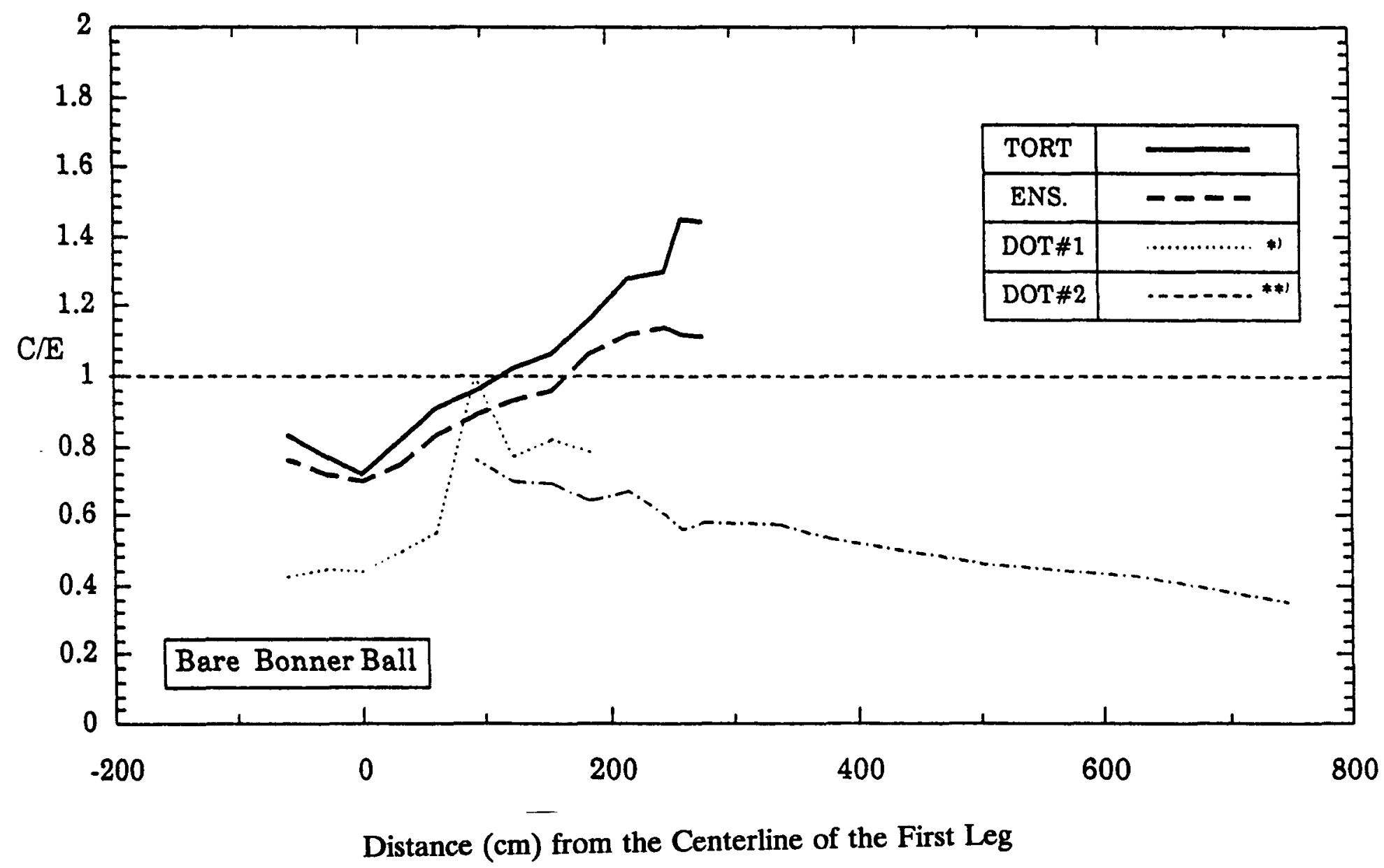

Fig. 13-1. C/E Values for the Bare Bonner Ball Count Rate Along the Centerline of the Second Leg of the Chaseway.

") Radial Diatribution From Firat-Leg Calculation

**) Axial Distribution From Second-Leg Calculation 


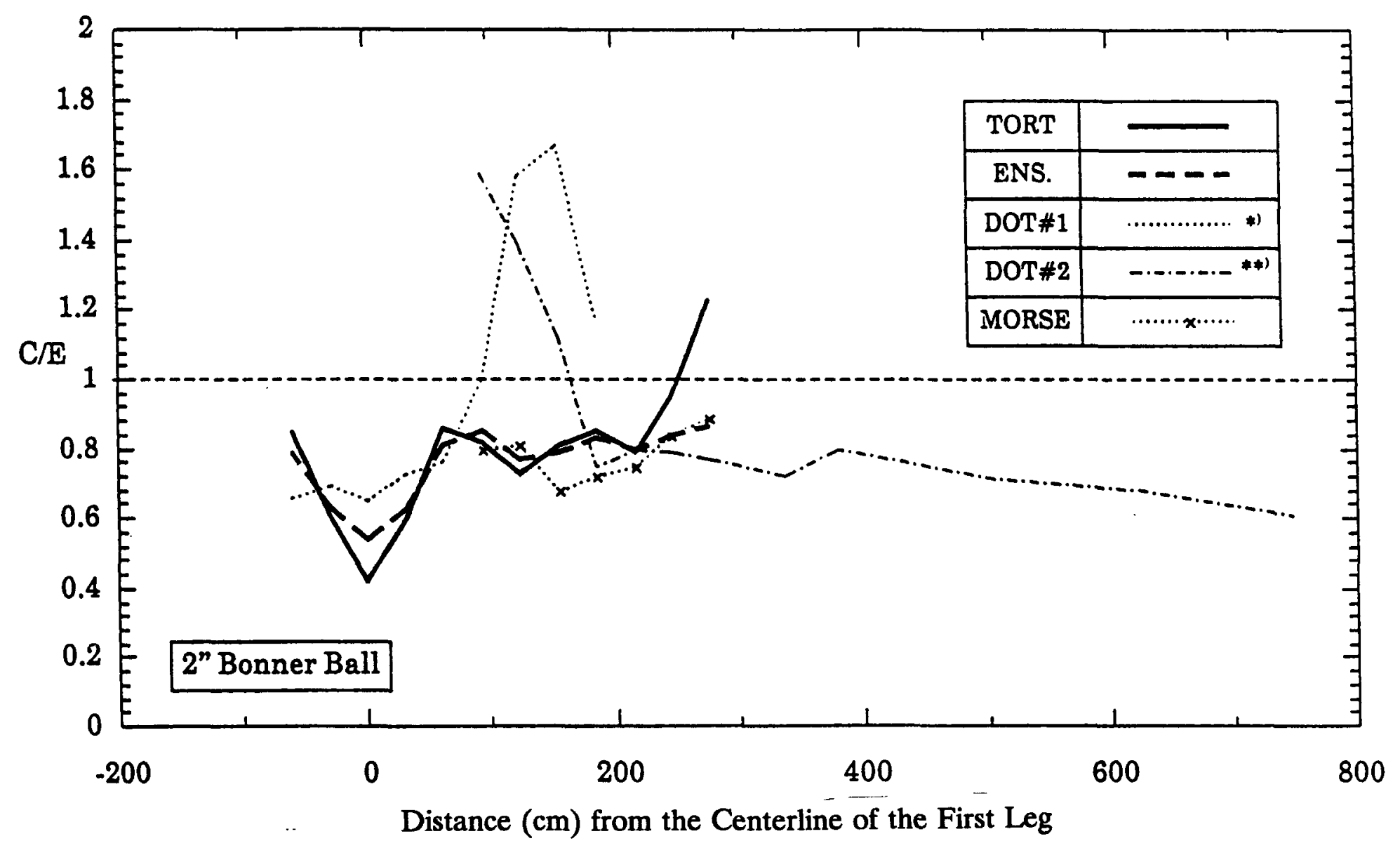

Fig. 13-2. C/E Values for the 2-inch Bonner Ball Count Rate Along the Centerline of the Second Leg of the Chaseway.

") Radial Distribution From First-Leg Calculation

**) Axial Distribution From Second-Leg Calculation 


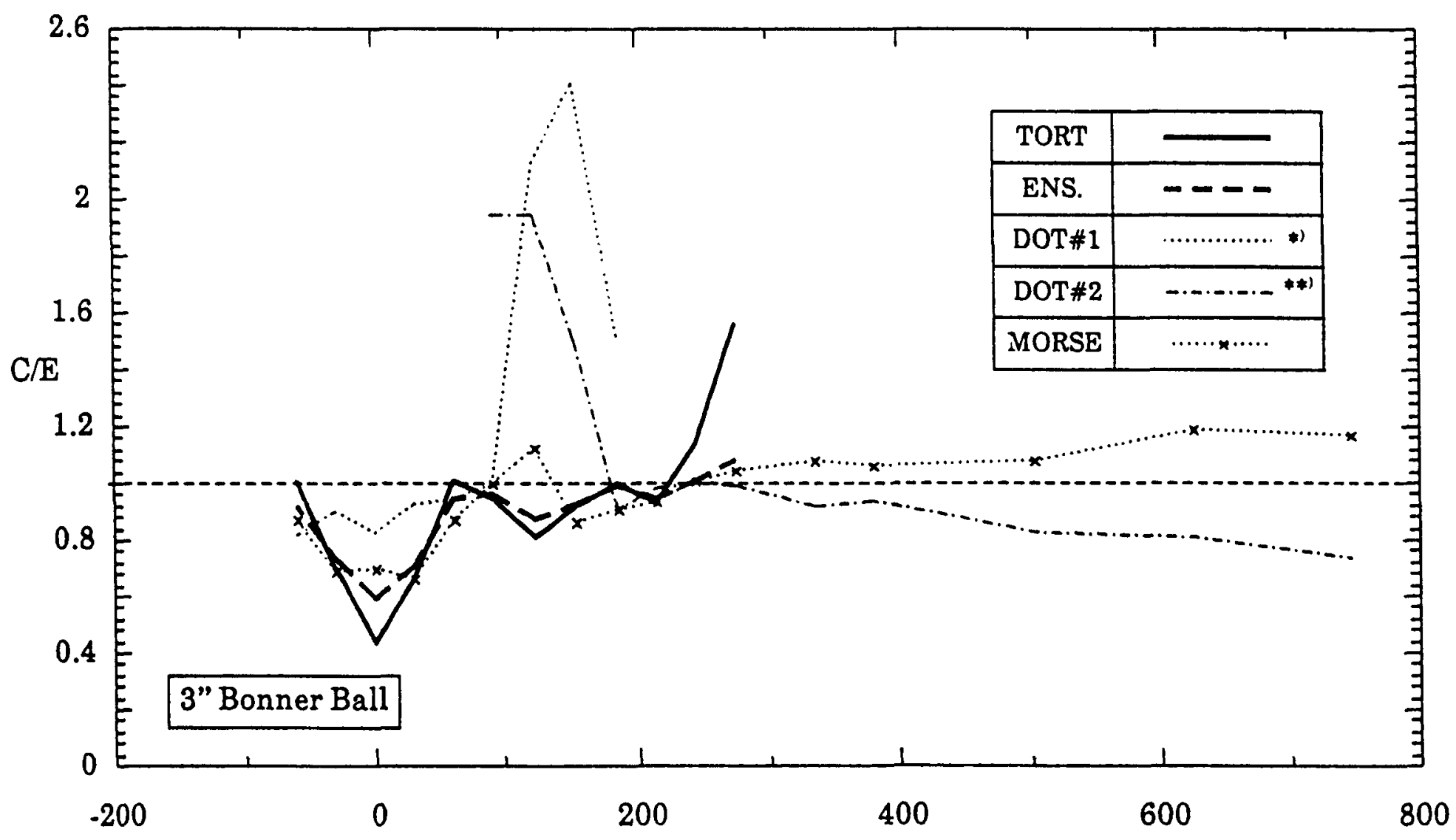

Distance $(\mathrm{cm})$ from the Centerline of the First Leg

Fig. 13-3. C/E Values for the 3-inch Bonner Ball Count Rate Along the Centerline of the Second Leg of the Chaseway.

*) Radial Distribution From Fint-Leg Calculation

*) Axial Distribution From Second-Leg Calculation 
Table 5-2. Comparison of Calculated and Measured 2-inch Bonner Ball Count Rates Along the Centerline of the First Leg of the Chaseway.

\begin{tabular}{|c|c|c|c|c|c|c|c|}
\hline \multirow[b]{2}{*}{$\begin{array}{c}\text { Position } \\
\text { No. }\end{array}$} & \multirow{2}{*}{$\begin{array}{l}\text { Distance from } \\
\text { Na Tank } \\
\text { (cm) }\end{array}$} & \multirow[b]{2}{*}{$\begin{array}{l}\text { Measurement } \\
(\mathrm{cps} / \mathrm{W})\end{array}$} & \multicolumn{5}{|c|}{$\mathrm{C} / \mathrm{E}$} \\
\hline & & & $\begin{array}{c}\text { TORT } \\
\text { (weighted) }\end{array}$ & $\begin{array}{l}\text { TORT } \\
\text { (nodal) }\end{array}$ & $\begin{array}{l}\text { ENSEM- } \\
\text { BLE }\end{array}$ & $\begin{array}{c}\text { DOT } \\
\text { (1st. leg, } \\
\text { on axis) }\end{array}$ & MORSE \\
\hline I-A-1 & 104.46 & $8.30 \mathrm{E}+00$ & 0.84 & 0.85 & 0.87 & 0.92 & 0.43 \\
\hline I-A-2 & 134.94 & $6.00 \mathrm{E}+00$ & 0.88 & 0.89 & 0.95 & 0.95 & 0.60 \\
\hline I-A-3 & 165.42 & $4.55 \mathrm{E}+00$ & 0.88 & 0.91 & 0.97 & 0.89 & 0.79 \\
\hline I-A-4 & 195.90 & $3.55 E+00$ & 0.86 & 0.93 & 0.93 & 0.84 & 0.99 \\
\hline I-A-5 & 218.92 & $3.12 \mathrm{E}+00$ & 0.81 & 0.84 & 0.84 & 0.81 & 0.79 \\
\hline I-A-6 & 220.35 & $2.92 \mathrm{E}+00$ & 0.87 & 0.89 & 0.88 & 0.86 & - \\
\hline I-A-7 & 249.71 & $2.55 \mathrm{E}+00$ & 0.82 & 0.86 & 0.73 & 0.78 & 0.71 \\
\hline I-A-8 & 280.19 & $2.13 E+00$ & 0.56 & 0.68 & 0.63 & 0.75 & 0.52 \\
\hline I-A-9 & 310.67 & $1.85 \mathrm{E}+00$ & 0.43 & 0.48 & 0.55 & 0.68 & 0.59 \\
\hline I-A-10 & 341.15 & $1.63 \mathrm{E}+00$ & 0.50 & 0.52 & 0.54 & 0.77 & 0.55 \\
\hline I-A-11 & 371.63 & $1.48 \mathrm{E}+00$ & 0.48 & 0.53 & 0.53 & 0.78 & 0.59 \\
\hline I-A-12 & 402.11 & $1.38 \mathrm{E}+00$ & 0.48 & 0.54 & 0.52 & 0.82 & 0.61 \\
\hline I-A-13 & 425.61 & $1.37 \mathrm{E}+00$ & 0.47 & 0.56 & 0.50 & 0.87 & 0.62 \\
\hline
\end{tabular}


Table 5-3. Comparison of Calculated and Measured 3-inch Bonner Ball Count Rates Along the Centerline of the First Leg of the Chaseway.

\begin{tabular}{|c|c|c|c|c|c|c|c|}
\hline \multirow[b]{2}{*}{$\begin{array}{c}\text { Position } \\
\text { No. }\end{array}$} & \multirow{2}{*}{$\begin{array}{l}\text { Distance from } \\
\text { Na Tank } \\
\text { (cm) }\end{array}$} & \multirow[b]{2}{*}{$\begin{array}{l}\text { Measurement } \\
\quad(\operatorname{cps} / \mathrm{W})\end{array}$} & \multicolumn{5}{|c|}{$\mathrm{C} / \mathrm{E}$} \\
\hline & & & $\begin{array}{c}\text { TORT } \\
\text { (weighted) }\end{array}$ & $\begin{array}{l}\text { TORT } \\
\text { (nodal) }\end{array}$ & $\begin{array}{c}\text { ENSEM- } \\
\text { BLE }\end{array}$ & $\begin{array}{c}\text { DOT } \\
\text { (1st. leg, } \\
\text { on axis) }\end{array}$ & MORSE \\
\hline I-A-1 & 104.46 & $8.15 \mathrm{E}+01$ & 0.98 & 0.99 & 1.01 & 1.07 & 0.56 \\
\hline I-A-2 & 134.94 & $5.87 \mathrm{E}+01$ & 1.03 & 1.02 & 1.10 & 1.10 & 0.77 \\
\hline I-A-3 & 165.42 & $4.35 E+01$ & 1.02 & 1.05 & 1.13 & 1.03 & 0.98 \\
\hline I-A-4 & 195.90 & $3.37 \mathrm{E}+01$ & 0.95 & 1.03 & 1.05 & 0.97 & 1.18 \\
\hline I-A-5 & 219.08 & $2.91 \mathrm{E}+01$ & 0.90 & 0.93 & 0.94 & 0.95 & 0.97 \\
\hline I-A-6 & 220.98 & $2.79 \mathrm{E}+01$ & 0.94 & 0.96 & 0.96 & 0.97 & - \\
\hline I-A-7 & 249.56 & $2.35 E+01$ & 0.90 & 0.94 & 0.80 & 0.92 & 0.86 \\
\hline I-A-8 & 280.04 & $1.95 \mathrm{E}+01$ & 0.58 & 0.71 & 0.65 & 0.88 & 0.60 \\
\hline I-A-9 & 310.52 & $1.67 \mathrm{E}+01$ & 0.42 & 0.47 & 0.56 & 0.81 & 0.69 \\
\hline I-A-10 & 341.00 & $1.45 \mathrm{E}+01$ & 0.49 & 0.51 & 0.54 & 0.92 & 0.61 \\
\hline $1-A-11$ & 371.48 & $1.30 \mathrm{E}+01$ & 0.47 & 0.52 & 0.53 & 0.92 & 0.66 \\
\hline I-A-12 & 401.96 & $1.23 E+01$ & 0.46 & 0.52 & 0.50 & 0.94 & 0.66 \\
\hline I-A-13 & 425.61 & $1.18 \mathrm{E}+01$ & 0.46 & 0.56 & 0.50 & 1.02 & 0.70 \\
\hline
\end{tabular}


Table 5-4. Comparison of Calculated and Measured 6-inch Bonner Ball Count Rates Along the Centerline of the First Leg of the Chaseway.

\begin{tabular}{|c|c|c|c|c|c|c|c|}
\hline \multirow[b]{2}{*}{$\begin{array}{c}\text { Position } \\
\text { No. }\end{array}$} & \multirow{2}{*}{$\begin{array}{c}\text { Distance from } \\
\text { Na Tank } \\
\text { (cm) }\end{array}$} & \multirow[b]{2}{*}{$\begin{array}{c}\text { Measurement } \\
(\mathrm{cps} / \mathrm{W})\end{array}$} & \multicolumn{5}{|c|}{$\mathrm{C} / \mathrm{E}$} \\
\hline & & & $\begin{array}{c}\text { TORT } \\
\text { (weighted) }\end{array}$ & $\begin{array}{l}\text { TORT } \\
\text { (nodal) }\end{array}$ & $\begin{array}{l}\text { ENSEM- } \\
\text { BLE }\end{array}$ & $\begin{array}{c}\text { DOT } \\
\text { (1st. leg, } \\
\text { on axis) }\end{array}$ & MORSE \\
\hline I-A-1 & 104.46 & $9.84 \mathrm{E}+01$ & 0.88 & 0.89 & 0.90 & 0.96 & 0.57 \\
\hline I-A-2 & 134.94 & $6.70 \mathrm{E}+01$ & 0.97 & 0.97 & 1.04 & 1.04 & 0.78 \\
\hline I-A-3 & 165.42 & $4.93 E+01$ & 0.95 & 0.98 & 1.06 & 0.97 & 0.97 \\
\hline I-A-4 & 195.90 & $3.81 \mathrm{E}+01$ & 0.86 & 0.93 & 0.97 & 0.91 & 1.19 \\
\hline I-A-5 & 219.71 & $3.09 \mathrm{E}+01$ & 0.86 & 0.88 & 0.90 & 0.94 & 1.01 \\
\hline I-A-6 & 220.03 & $3.14 \mathrm{E}+01$ & 0.84 & 0.86 & 0.88 & 0.92 & - \\
\hline I-A-7 & 250.19 & $2.49 \mathrm{E}+01$ & 0.83 & 0.87 & 0.74 & 0.91 & 0.90 \\
\hline I-A-8 & 280.67 & $2.06 \mathrm{E}+01$ & 0.51 & 0.64 & 0.59 & 0.86 & 0.59 \\
\hline I-A-9 & 311.15 & $1.75 \mathrm{E}+01$ & 0.36 & 0.40 & 0.50 & 0.82 & 0.68 \\
\hline I-A-10 & 341.63 & $1.51 \mathrm{E}+01$ & 0.43 & 0.45 & 0.47 & 0.91 & 0.59 \\
\hline I-A-11 & 372.11 & $1.36 \mathrm{E}+01$ & 0.40 & 0.44 & 0.45 & 0.90 & 0.63 \\
\hline I-A-12 & 402.59 & $1.24 \mathrm{E}+01$ & 0.40 & 0.46 & 0.44 & 0.94 & 0.65 \\
\hline I-A-13 & 425.61 & $1.19 \mathrm{E}+01$ & 0.40 & 0.49 & 0.44 & 1.02 & 0.69 \\
\hline
\end{tabular}


Table 5-5. Comparison of Calculated and Measured 10-inch Bonner Ball Count Rates Along the Centerline of the First Leg of the Chaseway.

\begin{tabular}{|c|c|c|c|c|c|c|c|}
\hline \multirow[b]{2}{*}{$\begin{array}{c}\text { Position } \\
\text { No. }\end{array}$} & \multirow{2}{*}{$\begin{array}{c}\text { Distance from } \\
\text { Na Tank } \\
\text { (cm) }\end{array}$} & \multirow[b]{2}{*}{$\begin{array}{c}\text { Measurement } \\
(\operatorname{cps} / W)\end{array}$} & \multicolumn{5}{|c|}{$C / E$} \\
\hline & & & $\begin{array}{c}\text { TORT } \\
\text { (weighted) }\end{array}$ & $\begin{array}{l}\text { TORT } \\
\text { (nodal) }\end{array}$ & $\begin{array}{l}\text { ENSEM- } \\
\text { BLE }\end{array}$ & $\begin{array}{c}\text { DOT } \\
\text { (1st. leg. } \\
\text { on axis) }\end{array}$ & MORSE \\
\hline I-A-I & 104.46 & $1.77 \mathrm{E}+01$ & 0.85 & 0.86 & 0.87 & 0.93 & 0.55 \\
\hline$I-A-2$ & 134.94 & $1.25 E+01$ & 0.91 & 0.90 & 0.97 & 0.97 & 0.74 \\
\hline I-A-3 & 165.42 & $9.15 E+00$ & 0.89 & 0.92 & 1.00 & 0.91 & 0.93 \\
\hline$I-A-4$ & 195.90 & $6.88 E+00$ & 0.82 & 0.89 & 0.93 & 0.87 & 1.16 \\
\hline I-A-5,6 & 220.03 & $5.76 \mathrm{E}+00$ & 0.79 & 0.81 & 0.85 & 0.87 & 0.96 \\
\hline- & $\cdot$ & - & - $\ldots$ & - & - & - & - \\
\hline I-A-7 & 250.19 & $4.68 \mathrm{E}+00$ & 0.76 & 0.79 & 0.68 & 0.84 & 0.84 \\
\hline I-A-8 & 280.67 & $3.90 E+00$ & 0.46 & 0.58 & 0.54 & 0.79 & 0.54 \\
\hline I-A-9 & 311.15 & $3.32 E+00$ & 0.33 & 0.36 & 0.45 & 0.75 & 0.63 \\
\hline 1-A-10 & 341.63 & $2.85 \mathrm{E}+00$ & 0.38 & 0.40 & 0.43 & 0.84 & 0.55 \\
\hline$I-A-11$ & 372.11 & $2.53 E+D 0$ & 0.36 & 0.40 & 0.41 & 0.84 & 0.59 \\
\hline I-A-12 & 402.59 & $2.32 E+00$ & 0.36 & 0.41 & 0.40 & 0.88 & 0.60 \\
\hline I.A-13 & 424.66 & $2.20 E+00$ & 0.37 & 0.45 & 0.40 & 0.95 & 0.64 \\
\hline
\end{tabular}


Table 6-1. Comparison of Calculated and Measured Bare Bonner Ball Count Rates Along the Centerline of the Second Leg of the Chaseway.

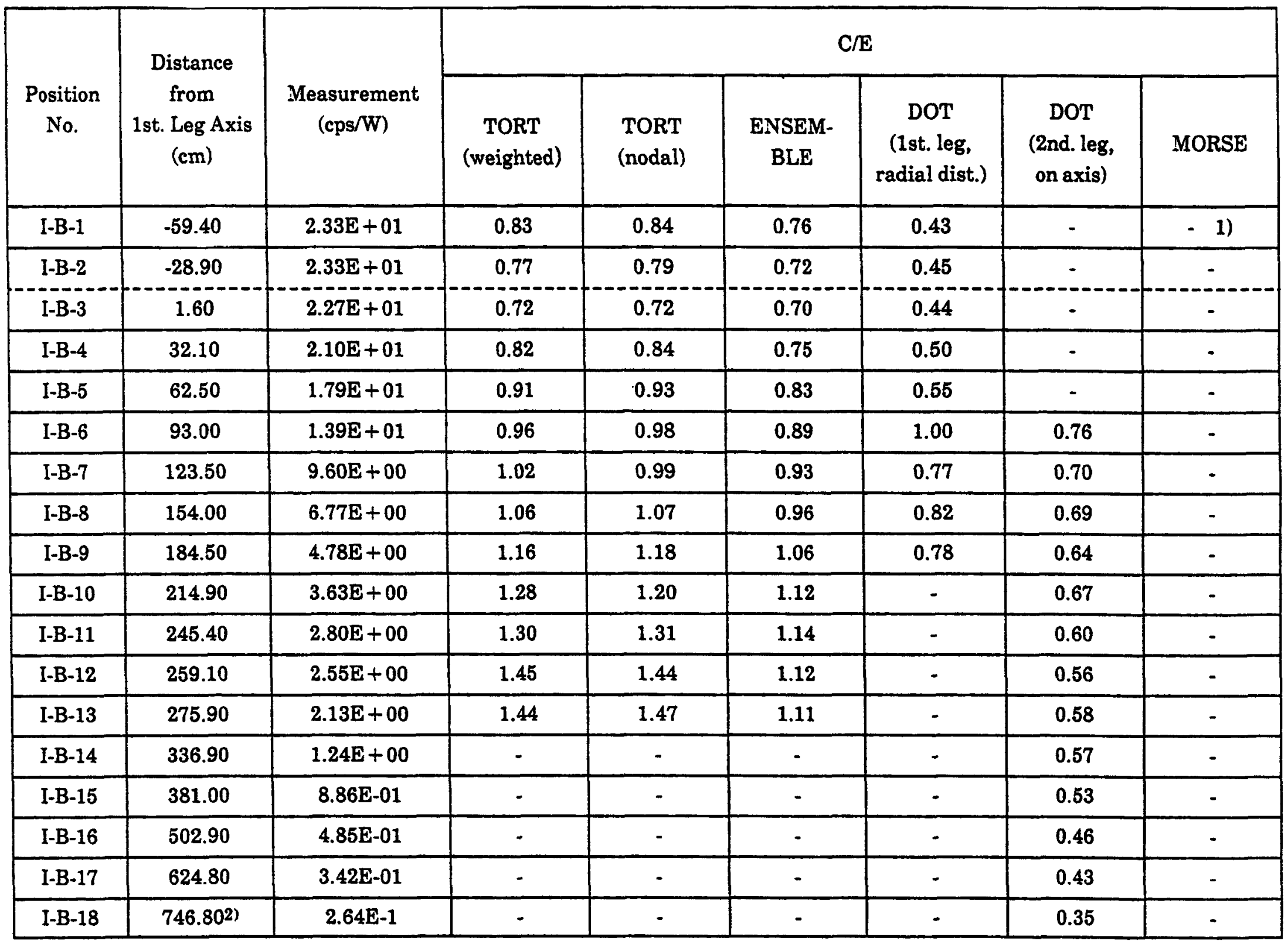

1) Not estimated. (Themal neutron was not included in MORSE calculation.) 2) Axis of the 3rd. leg. 
Table 6-2. Comparison of Calculated and Measured 2-inch Bonner Ball Count Rates Along the Centerline of the Second Leg of the Chaseway.

\begin{tabular}{|c|c|c|c|c|c|c|c|c|}
\hline \multirow[b]{2}{*}{$\begin{array}{c}\text { Position } \\
\text { No. }\end{array}$} & \multirow{2}{*}{$\begin{array}{l}\text { Distance } \\
\text { from } \\
\text { 1st. Leg Axis } \\
\text { (cm) }\end{array}$} & \multirow[b]{2}{*}{$\begin{array}{l}\text { Measurement } \\
\quad(\mathrm{cps} / \mathrm{W})\end{array}$} & \multicolumn{6}{|c|}{$\mathrm{C} / \mathrm{E}$} \\
\hline & & & $\begin{array}{c}\text { TORT } \\
\text { (weighted) }\end{array}$ & $\begin{array}{c}\text { TORT } \\
\text { (nodal) }\end{array}$ & $\begin{array}{l}\text { ENSEM- } \\
\text { BLE }\end{array}$ & $\begin{array}{c}\text { DOT } \\
\text { (1st. leg, } \\
\text { radial dest.) }\end{array}$ & $\begin{array}{c}\text { DOT } \\
\text { (2nd. leg, } \\
\text { on axis) }\end{array}$ & MORSE \\
\hline 1-B-1 & -59.70 & $1.97 \mathrm{E}+00$ & 0.85 & 0.97 & 0.79 & 0.66 & - & - \\
\hline I-B-2 & -29.20 & $1.98 \mathrm{E}+00$ & 0.60 & 0.71 & 0.63 & 0.69 & - & - \\
\hline 1-B-3 & 1.30 & $1.95 \mathrm{E}+00$ & 0.42 & 0.47 & 0.54 & 0.65 & - & - \\
\hline I-B-4 & 31.80 & $1.88 \mathrm{E}+00$ & 0.60 & 0.72 & 0.63 & 0.73 & - & - \\
\hline I-B-5 & 62.20 & $1.70 \mathrm{E}+00$ & 0.86 & 0.99 & 0.81 & 0.76 & $\cdot$ & - \\
\hline I-B-6 & 92.70 & $1.23 E+00$ & 0.82 & 0.96 & 0.85 & 1.00 & 1.59 & 0.80 \\
\hline $1-B-7$ & 123.20 & $6.17 \mathrm{E}-01$ & 0.73 & 0.74 & 0.77 & 1.58 & 1.39 & 0.81 \\
\hline I-B-8 & 153.70 & $3.82 \mathrm{E}-01$ & 0.81 & 0.95 & 0.79 & 1.67 & 1.12 & 0.68 \\
\hline I-B-9 & 184.20 & 2.62E-01 & 0.85 & 0.93 & 0.83 & 1.18 & 0.75 & 0.72 \\
\hline I-B-10 & 214.60 & $1.97 \mathrm{E}-01$ & 0.79 & 0.85 & 0.80 & - & 0.80 & 0.75 \\
\hline I-B-11 & 245.10 & $1.50 \mathrm{E}-01$ & 0.95 & 0.97 & 0.84 & - & 0.79 & 0.84 \\
\hline I-B-12 & - & - & - & - & - & - & - & - \\
\hline I-B-13 & 275.60 & $1.17 \mathrm{E}-01$ & 1.23 & 1.35 & 0.87 & - & 0.77 & 0.89 \\
\hline I-B-14 & 336.60 & $6.58 \mathrm{E}-02$ & - & - & - & - & 0.72 & - \\
\hline I-B-15 & 381.00 & $3.87 \mathrm{E}-02$ & - & - & - & - & 0.80 & - \\
\hline I-B-16 & 502.90 & $1.61 \mathrm{E}-02$ & - & $\cdot$ & - & - & 0.71 & - \\
\hline 1-B-17 & 624.80 & $9.42 \mathrm{E}-03$ & - & $\cdot$ & $\cdot$ & - & 0.68 & $\cdot$ \\
\hline I-B-18 & $746.801)$ & $6.43 E-03$ & - & - & - & - & 0.61 & - \\
\hline
\end{tabular}

1) Axis of the 3rd leg. 
Table 6-3. Comparison of Calculated and Measured 3-inch Bonner Ball Count Rates Along the Centerline of the Second Leg of the Chaseway.

\begin{tabular}{|c|c|c|c|c|c|c|c|c|}
\hline \multirow[b]{2}{*}{$\begin{array}{c}\text { Position } \\
\text { No. }\end{array}$} & \multirow{2}{*}{$\begin{array}{l}\text { Distance } \\
\text { from } \\
\text { 1st. Leg Axis } \\
\text { (cm) }\end{array}$} & \multirow[b]{2}{*}{$\begin{array}{l}\text { Measurement } \\
\quad(\mathrm{cps} / \mathrm{W})\end{array}$} & \multicolumn{6}{|c|}{$\mathrm{C} / \mathrm{E}$} \\
\hline & & & $\begin{array}{c}\text { TORT } \\
\text { (weighted) }\end{array}$ & $\begin{array}{l}\text { TORT } \\
\text { (nodal) }\end{array}$ & $\begin{array}{l}\text { ENSEM- } \\
\text { BLE }\end{array}$ & $\begin{array}{c}\text { DOT } \\
\text { (1st. leg, } \\
\text { radial dest.) }\end{array}$ & $\begin{array}{c}\text { DOT } \\
\text { (2nd. leg, } \\
\text { on axis) }\end{array}$ & MORSE \\
\hline I-B-1 & -61.00 & $1.70 \mathrm{E}+01$ & 1.01 & 1.18 & 0.92 & 0.82 & - & 0.87 \\
\hline I-B-2 & -30.50 & $1.66 \mathrm{E}+01$ & 0.70 & 0.83 & 0.74 & 0.90 & - & 0.69 \\
\hline I-B-3 & 0.00 & $1.65 \mathrm{E}+01$ & 0.44 & 0.50 & 0.59 & 0.83 & - & 0.70 \\
\hline I-B-4 & 30.50 & $1.61 \mathrm{E}+01$ & 0.66 & 0.79 & 0.71 & 0.93 & - & 0.66 \\
\hline I-B-5 & 61.00 & $1.47 \mathrm{E}+01$ & 1.01 & 1.15 & 0.95 & 0.95 & - & 0.87 \\
\hline I-B-6 & 91.40 & $1.13 E+01$ & 0.95 & 1.12 & 0.96 & 1.00 & 1.95 & 1.00 \\
\hline I-B-7 & 121.90 & $4.98 \mathrm{E}+00$ & 0.81 & 0.82 & 0.87 & 2.13 & 1.95 & 1.13 \\
\hline I-B-8 & 152.40 & $2.87 \mathrm{E}+00$ & 0.92 & 1.10 & 0.93 & 2.41 & 1.50 & 0.86 \\
\hline I-B-9 & 182.90 & $1.93 E+00$ & 1.00 & 1.12 & 0.99 & 1.52 & 0.91 & 0.91 \\
\hline I-B-10 & 213.40 & $1.43 \mathrm{E}+00$ & 0.93 & 1.03 & 0.95 & - & 0.98 & 0.94 \\
\hline I-B-11 & 243.80 & $1.07 E+00$ & 1.14 & 1.17 & 1.01 & - & 1.00 & 1.01 \\
\hline I-B-12 & - & - & - & - & - & - & - & - \\
\hline I-B-13 & 274.30 & 8.20E-01 & 1.56 & 1.71 & 1.08 & - & 0.99 & 1.05 \\
\hline I-B-14 & 335.30 & $4.58 \mathrm{E}-01$ & - & - & - & - & 0.92 & 1.08 \\
\hline I-B-15 & 381.00 & $2.90 \mathrm{E}-01$ & - & - & - & - & 0.94 & 1.06 \\
\hline I-B-16 & 502.90 & $1.19 \mathrm{E}-01$ & - & - & - & - & 0.83 & 1.08 \\
\hline I-B-17 & 624.80 & $6.80 \mathrm{E}-02$ & - & - & $\cdot$ & - & 0.81 & 1.19 \\
\hline I-B-18 & $746.80^{11}$ & $4.53 E-02$ & - & - & - & - & 0.74 & 1.17 \\
\hline
\end{tabular}

1) Axis of the 3rd leg. 
Table 6-4. Comparison of Calculated and Measured 6-inch Bonner Ball Count Rates

Along the Centerline of the Second Leg of the Chaseway.

\begin{tabular}{|c|c|c|c|c|c|c|c|c|}
\hline \multirow{2}{*}{$\begin{array}{l}\text { Position } \\
\text { No. }\end{array}$} & \multirow{2}{*}{$\begin{array}{c}\text { Distance } \\
\text { from } \\
\text { 1st. Leg Axis } \\
\text { (cm) }\end{array}$} & \multirow{2}{*}{$\begin{array}{l}\text { Measurement } \\
(\operatorname{cps} / \mathrm{W})\end{array}$} & \multicolumn{6}{|c|}{$\mathrm{C} / \mathrm{E}$} \\
\hline & & & $\begin{array}{c}\text { TORT } \\
\text { (weighted) }\end{array}$ & $\begin{array}{l}\text { TORT } \\
\text { (nodal) }\end{array}$ & $\begin{array}{l}\text { ENSEM- } \\
\text { BLE }\end{array}$ & $\begin{array}{c}\text { DOT } \\
\text { (1st. leg, } \\
\text { radial dest.) }\end{array}$ & $\begin{array}{l}\text { DOT } \\
\text { (2nd. leg, } \\
\text { on axis) }\end{array}$ & MORSE \\
\hline I-B-1 & .60 .60 & $1.78 \mathrm{E}+01$ & 0.97 & 1.13 & 0.88 & 0.78 & - & 0.87 \\
\hline I-B-2 & .30 .20 & $1.82 \mathrm{E}+01$ & 0.61 & 0.72 & 0.65 & 0.87 & - & 0.65 \\
\hline I-B-3 & 0.30 & $1.82 \mathrm{E}+01$ & 0.37 & 0.42 & 0.50 & 0.80 & . & 0.65 \\
\hline I-B-4 & 30.80 & $1.75 \mathrm{E}+01$ & 0.58 & 0.70 & 0.63 & 0.90 & - & 0.63 \\
\hline I-B-5 & 61.30 & $1.58 E+01$ & 0.94 & 1.09 & 0.89 & 0.93 & - & 0.85 \\
\hline I-B-6 & 91.80 & $1.16 \mathrm{E}+01$ & 0.91 & 1.08 & 0.94 & 1.00 & 2.05 & 1.06 \\
\hline I-B-7 & 122.20 & $4.92 \mathrm{E}+00$ & 0.73 & 0.74 & 0.80 & 2.26 & 2.02 & 1.17 \\
\hline I-B-8 & 152.70 & $2.73 E+00$ & 0.87 & 1.06 & 0.87 & 2.60 & 1.49 & 0.86 \\
\hline I-B-9 & 183.20 & $1.82 \mathrm{E}+00$ & 0.94 & 1.05 & 0.93 & 1.52 & 0.86 & 0.90 \\
\hline I-B-10 & 213.70 & $1.29 \mathrm{E}+00$ & 0.90 & 1.01 & 0.92 & - & 0.97 & 0.95 \\
\hline I-B-11 & 244.20 & $9.98 \mathrm{E}-01$ & 1.10 & 1.13 & 0.96 & - & 0.95 & 0.75 \\
\hline I-B-12 & - & - & - & - & - & - & $\cdot$ & - \\
\hline I-B-13 & 274.30 & $7.65 \mathrm{E}-01$ & 1.52 & 1.67 & 1.03 & - & 0.94 & 0.76 \\
\hline I-B-14 & 335.60 & $4.15 \mathrm{E}-01$ & $\cdot$ & - & - & - & 0.90 & 1.14 \\
\hline I-B-15 & 381.00 & 2.67E-01 & - & - & - & - & 0.91 & 1.10 \\
\hline I-B-16 & 502.90 & $1.09 \mathrm{E}-01$ & - & $\cdot$ & - & - & 0.81 & 1.09 \\
\hline I-B-17 & 624.80 & $6.15 \mathrm{E}-02$ & - & - & . & - & 0.79 & 1.16 \\
\hline I-B-18 & $746.80^{11}$ & $4.05 \mathrm{E}-02$ & - & - & - & - & 0.72 & 1.16 \\
\hline
\end{tabular}

1) Axis of the 3rd. leg. 
Table 6-5. Comparison of Calculated and Measured 10-inch Bonner Ball Count Rates Along the Centerline of the Second Leg of the Chaseway.

\begin{tabular}{|c|c|c|c|c|c|c|c|c|}
\hline \multirow{2}{*}{$\begin{array}{l}\text { Position } \\
\text { No. }\end{array}$} & \multirow{2}{*}{$\begin{array}{l}\text { Distance } \\
\text { from } \\
\text { 1st. Leg Axis } \\
\text { (cm) }\end{array}$} & \multirow{2}{*}{$\begin{array}{l}\text { Measurement } \\
\qquad(\mathrm{cps} / \mathrm{W})\end{array}$} & \multicolumn{6}{|c|}{$\mathrm{C} / \mathrm{E}$} \\
\hline & & & $\begin{array}{c}\text { TORT } \\
\text { (weighted) }\end{array}$ & $\begin{array}{l}\text { TORT } \\
\text { (nodal) }\end{array}$ & $\begin{array}{l}\text { ENSEM- } \\
\text { BLE }\end{array}$ & $\begin{array}{c}\text { DOT } \\
\text { (1st. leg, } \\
\text { radial dest.) }\end{array}$ & $\begin{array}{c}\text { DOT } \\
\text { (2nd. leg, } \\
\text { on axis) }\end{array}$ & MORSE \\
\hline I-B-1 & -61.00 & $3.33 E+00$ & 0.89 & 1.05 & 0.81 & 0.77 & - & 0.81 \\
\hline $1-B-2$ & -30.50 & $3.37 E+00$ & 0.56 & 0.67 & 0.60 & 0.82 & - & 0.61 \\
\hline I-B-3 & 0.00 & $3.50 \mathrm{E}+00$ & 0.32 & 0.37 & 0.44 & 0.72 & . & 0.59 \\
\hline [-B-4 & 35.00 & $3.35 \mathrm{E}+00$ & 0.55 & 0.66 & 0.56 & 0.82 & - & 0.57 \\
\hline I-B-5 & 61.00 & $3.13 E+00$ & 0.82 & 0.94 & 0.78 & 0.82 & - & 0.75 \\
\hline I-B-6 & 91.40 & $2.20 \mathrm{E}+00$ & 0.84 & 1.00 & 0.86 & 1.00 & 1.89 & 1.00 \\
\hline 1-B-7 & 121.90 & $9.37 \mathrm{E}-01$ & 0.66 & 0.66 & 0.72 & 2.06 & 1.87 & 1.09 \\
\hline I-B-8 & 152.40 & $5.10 \mathrm{E}-01$ & 0.79 & 0.96 & 0.79 & 2.43 & 1.38 & 0.78 \\
\hline I-B-9 & 182.90 & $3.40 \mathrm{E}-01$ & 0.86 & 0.96 & 0.84 & 1.40 & 0.77 & 0.82 \\
\hline I-B-10 & 213.40 & $2.47 \mathrm{E}-01$ & 0.80 & 0.90 & 0.82 & - & 0.86 & 0.84 \\
\hline I-B-11 & 243.80 & $1.83 \mathrm{E}-01$ & 1.02 & 1.05 & 0.89 & - & 0.88 & 0.89 \\
\hline I-B-12 & - & - & - & - & - & - & - & - \\
\hline I-B-13 & 274.30 & $1.41 \mathrm{E}-01$ & 1.40 & 1.54 & 0.96 & - & 0.86 & 0.89 \\
\hline I-B-14 & 335.30 & $7.78 \mathrm{E}-02$ & - & - & $\cdot$ & - & 0.81 & 1.04 \\
\hline I-B-15 & 381.00 & 4.77E-02 & $\cdot$ & - & $\cdot$ & - & 0.86 & 1.06 \\
\hline I-B-16 & 502.90 & $1.90 \mathrm{E}-02$ & - & - & - & - & 0.79 & 1.07 \\
\hline I-B-17 & 624.80 & $1.06 \mathrm{E}-02$ & - & - & - & - & 0.77 & 1.14 \\
\hline I-B-18 & $746.80^{1)}$ & $7.83 \mathrm{E}-03$ & - & - & $\cdot$ & - & 0.63 & 1.01 \\
\hline
\end{tabular}

1) Axis of the 3rd leg. 
the second leg, but the DOT3.5 and MORSE geometries included all of the second leg of the chaseway. This is reflected in the range of data given in the tables and plotted in the figures. Since the DOT3.5 calculations were bootstrapped at the bend in the chaseway, the plotted curves of the DOT3.5 results in Figs. 12 and Figs. 13 overlap at the bend (Radial traverse results from one calculation overlap axial traverse results from another calculation in the common regions of the two geometries.) In Figs. 13, the zero of the horizontal axis is at the centerline of the first leg of the chaseway.

From the tables and figures, one observes that the TORT and ENSEMBLE C/E values are good. However, near the centerline of the first leg, the TORT- and ENSEMBLE-calculated results show a dip in the count rate due to ray effects. The TORT C/E values increase anomalously at choke no. 3 . This problem should have been investigated further. However, it is beyond the scope of this study. The calculational behavior must not be a characteristic of 3-D radiation transport codes because the ENSEMBLE and MORSE C/E values do not increase in like manner. Except for the portion of the traverse across the first leg and where the TORT C/E values increase anomalously, the TORT, ENSEMBLE, and MORSE results are in good agreement with each other and with measured results. 


\section{CONCLUSIONS}

Results of comparisons of calculated and measured data for the CRBR prototypic coolant pipe chaseway neutron streaming experiment have been presented. Calculations were performed with several radiation transport codes, including DOT3.5 (2-D discrete ordinates), MORSE (3-D Monte Carlo), TORT (3-D discrete ordinates), and ENSEMBLE (3-D discrete ordinates). TORT calculations were performed using both the weighted-difference and nodal methods. ENSEMBLE used the weighted-difference method only. While the DOT3.5 calculations used a refined, biased quadrature, the TORT and ENSEMBLE calculations used rather coarse quadratures (equivalent to $S_{6}$ ). Separate DOT3.5 calculations were performed for each leg of the chaseway. Boundary fluxes from the first-leg calculation provided the source for the second-leg calculation.

Several general conclusions may be deduced from the comparisons of measured results with results from 3-D calculations performed with TORT and ENSEMBLE. First, except in the first leg where the calculated values dipped due to ray effects, calculated values were generally in good agreement with the measured values (10 to 15\%). Better agreement might have been achieved by increasing the number of spatial mesh and/or the number of angles in the quadrature set, but these could not be increased significantly due to computer time constraints. Convergence of the thermal-neutron flux was difficult and in all cases the iteration limit was reached before the convergence criterion was satisfied. Therefore, thermal-neutron fluxes for the three calculations (two TORT and one ENSEMBLE) differed mainly due to the lack of convergence. Second, the TORT calculations using the nodal and weighted-difference methods gave about the same results. While the nodal method is generally more accurate for coarse spatial meshes, more computer time is required for it than for the weighted-difference method. For these calculations, the accuracy achieved by using the nodal method was not worth the additional time required. Third, the comparisons of the TORT and ENSEMBLE results with the DOT3.5 results at the bend in the chaseway showed that the 3-D calculations give greatly improved results, especially for the bare Bonner ball count rate and by implication the thermal-neutron flux. Fourth, comparisons with MORSE results found the MORSE results worse in the first leg due to biasing but better in the second leg. The computer time used by the MORSE calculation was about one tenth that used by the TORT and ENSEMBLE calculations. However, with the added time for source preparation, developing estimating procedures, and performing test calculations to gauge the effects of input parameters, the MORSE computer time was comparable to that for TORT and ENSEMBLE.

For shielding calculations especially, it is desirable to save computer time as well as problem setup time. Therefore, one selects a computer code that is a leader in those characteristics. Other considerations are availability of the code, accuracy, ease of use, and the applicability of experience developed using other codes. Based on those criteria, TORT would be the code of choice because of (1) its competitive computer time, (2) its acceptable accuracy, (3) its relative ease of use, (4) its reasonable setup time, (5) its availability, and (6) the applicability of experience from the 1-D ANISN and 2-D DOT discrete ordinates radiation transport codes. 


\section{REFERENCES}

1. F. J. Muckenthaler and C. E. Clifford, "A Measurement of the Neutron Streaming in a CRBR Prototypic Coolant Chaseway," ORNL/TM-5901 (August, 1977).

2. K. Shirakata and T. Sanda, "Proc. of the Jasper Analysis Meeting Japanese Presentation," PNC-SA-0733 87-001.

3. T. Nishimura, K. Tada, H. Yokobori, and A. Sugawara, "Development of Discrete Ordinates SN Code in Three-Dimensional (X, Y, Z) Geometry for Shielding Design," Journal of Nucl. Sci. and Tech, 17 pp. 539-558 (1980).

4. Z. Suzuoki, K. Ikeda, T. Nishimura, K. Tada, and H. Yokobori, "Recent Development and Current Application of Three-Dimensional Discrete Ordinates Transport Codes," Proc. of ANS Topical Meeting on Physics and Shielding, Chicago (1984).

5. H. Yokobori, T. Nishimura, and K. Tada, "Application of a Three-Dimensional Discrete Ordinates Transport Code to Shielding Design and Analysis," Proc. of the Conference 1980 Advances in Reactor Physics and Shielding, pp. 414-425, Sun Valley (1980).

6. K. Sasaki and H. Yokobori, "Analysis of Global Neutron Streaming in a Large System with a Three-Dimensional Discrete Ordinates Transport Code, ENSEMBLE," Proc. of International Topic Meeting on Advances in Reactor Physics, Mathematics and Computation, Paris (1987).

7. W. A. Rhoades and R. L. Childs, "The TORT Three-Dimensional Discrete Ordinates Neutron/Photon Transport Code," ORNL-6268 (November, 1987).

8. M. B. Emmett, "The MORSE Monte Carlo Radiation Transport Code System," ORNL4972 (February 1975).

9. W. A. Rhoades and F. R. Mynatt, "The DOT III Two-Dimensional Discrete Ordinates Transport Code," ORNL/TM-4280 (September, 1973).

10. R. E. Maerker, "Discrete Ordinates Analysis of the TSF Experiment on Neutron Streaming in a CRBR Prototypic Coolant Pipe Chaseway," ORNL/TM-6497 (November, 1978).

11. ORNL Radiation Shielding Information Center, "100 Group Neutron Cross-Section Data Based on ENDF/B," RSIC Data Library Collection, DLC-2 (January 22, 1975).

12. "RSIC Computer Code Collection ANISN-ORNL" CCC-254 (September, 1988).

13. R. G. Soltesz, "DOQ - Discrete Ordinates Quadrature Code Manual," Internal Memorandum, NRD-68-718, (November 20, 1968).

14. M. B. Emmett, C. E. Burgart, and T. J. Hoffman, "DOMINO, A General Purpose Code for Coupling Discrete Ordinates and Monte Carlo Radiation Transport Calculations," ORNL-4853, (July, 1973). 


\section{APPENDIX I}





\section{APPENDIX I \\ Comparison of TORT and ENSEMBLE Results for Test Calculations Using a Dummy Source}

Test calculations were performed with TORT and ENSEMBLE to get general information about the three-dimensional transport codes. Calculational conditions for the test calculations were the same as those in Table 2 except for the boundary source. In the test calculations, the input boundary source was zero for all neutron energy groups except the 20th. For that group, a uniform boundary flux of $1 \mathrm{n} / \mathrm{cm}^{2} . s$.unit-weight was input across the opening and concrete surface of choke no. 1.

Fig. A.I shows plots of the flux error versus the number of iterations, and Table A.I gives numerical values of the flux error by iteration. The general conclusions resulting from the analysis of the results of the test calculations are as follows:

1. For TORT, the number of iterations and the convergence error were about the same for both the nodal and weighted-difference methods.

2. TORT and ENSEMBLE differed greatly in the flux error and the number of iterations required for convergence. For group 20, ENSEMBLE's convergence rate for the first 19 iterations was much faster than TORT's. After 19 iterations, ENSEMBLE's flux error oscillated between 1 and 4\%. The TORT convergence rate was slowed considerably after about eight iterations and the flux error remained rather large after 20 iterations. Differences between TORT and ENSEMBLE in the numbers of iterations required for convergence and the flux error after the last iteration for the CRBR prototypic coolant pipe chaseway experiment (see Section 4) were small compared to those for the test calculations. The large differences for the test calculations are attributed to a larger fraction of the source being incident on the choke no. 1 concrete and to a lack of a penetrating, high-energy source to feed the low-energy groups. Convergence rates for the high-energy groups are generally better than those for the lower energy groups. 

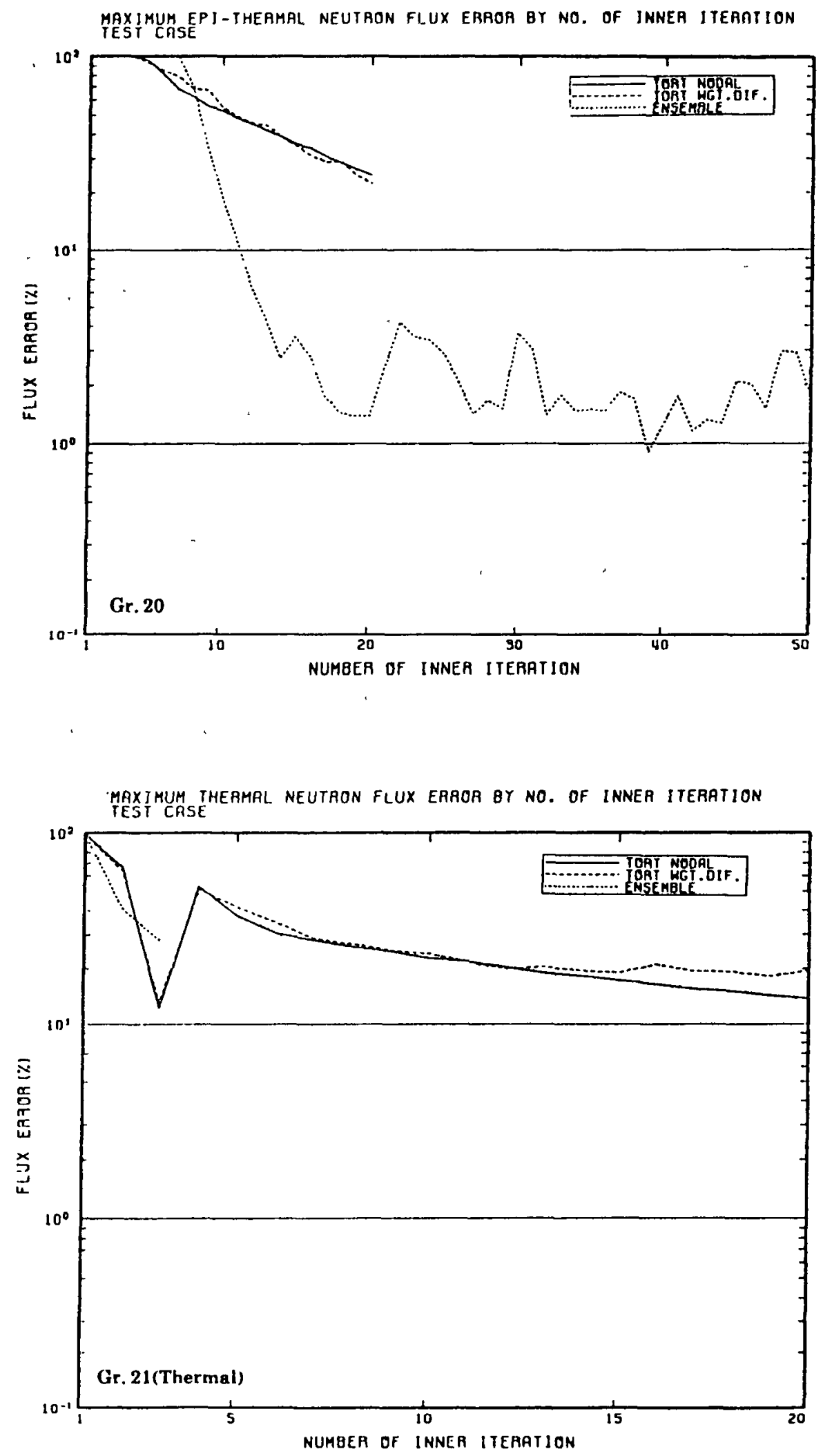

Fig. A.I. Convergence by Iteration of the Test Calculation Neutron Fluxes for Groups 20 and 21. 
Table A.I. Flux Error (\%) by Iteration of the Test Calculation Neutron Fluxes for Groups 20 and 21.

\begin{tabular}{|c|c|c|c|c|c|c|}
\hline \multirow{4}{*}{$\begin{array}{c}\text { Number of } \\
\text { Inner } \\
\text { Iterations }\end{array}$} & \multicolumn{6}{|c|}{ Flux Error (x) } \\
\hline & \multicolumn{3}{|c|}{ Group $20(0.414-1.13 \mathrm{eV})$} & \multicolumn{3}{|c|}{ Group 21 (below $0.414 \mathrm{eV}$ ) } \\
\hline & \multicolumn{2}{|c|}{ TORT } & \multirow[t]{2}{*}{ ENSEMBLE } & \multicolumn{2}{|c|}{ TORT } & \multirow[t]{2}{*}{ ENSEMBLE } \\
\hline & Nodal & Weighted & & Nodal & Weighted & \\
\hline $\begin{array}{l}1 \\
2 \\
3\end{array}$ & $\begin{array}{r}100.00 x \\
8.1 E+05 y \\
1.5 E+04 x\end{array}$ & $\begin{array}{r}100.00 x \\
102.00 x \\
-170.00 x\end{array}$ & $\begin{array}{l}\text { 2. } 0 E+04 x \\
\text { 8. } 1 E+13 x \\
\text { 1. } 4 E+03 x\end{array}$ & $\begin{array}{r}100.00 x \\
66.10 x \\
-12.20 x\end{array}$ & $\begin{array}{r}100.00 x \\
63.40 x \\
-13.10 x\end{array}$ & $\begin{array}{r}2853.00 x \\
40.85 x \\
28.04 x \\
\end{array}$ \\
\hline 4 & $220.00 x$ & $99.40 x$ & $6.6 \mathrm{E}+03 x$ & $53.30 x$ & $51.40 x$ & Execution \\
\hline 5 & $95.40 x$ & $92.70 x$ & $844.90 x$ & $37.70 x$ & $41.60 x$ & tine was \\
\hline 6 & $81.20 x$ & $84.90 \%$ & $374.70 x$ & $30.70 x$ & $34.80 \%$ & reached to \\
\hline 7 & $68.00 x$ & $79.00 \%$ & $137.80 x$ & $28.10 x$ & $28.80 x$ & 1 init. \\
\hline 8 & $62.60 \%$ & $68.20 \%$ & $69.86 x$ & $26.00 \%$ & $26.80 x$ & \\
\hline 9 & $55.50 \times$ & $67.20 x$ & $35.15 \%$ & $24.40 x$ & $24.80 x$ & \\
\hline 10 & $52.60 x$ & $54.70 x$ & $19.49 \%$ & $22.60 x$ & $23.80 x$ & \\
\hline 11 & $48.20 x$ & $49.70 x$ & $11.63 \%$ & $21.70 x$ & $21.70 x$ & \\
\hline 12 & $45.30 x$ & $45.90 x$ & $6.57 \%$ & $20.40 x$ & $19.90 \%$ & \\
\hline 13 & 41.80 저 & $44.50 x$ & $4.38 x$ & $18.90 x$ & $20.40 \%$ & \\
\hline 14 & $38.90 \mathrm{~d}$ & $38.60 x$ & 2.747 & $18.30 x$ & $19.50 \%$ & \\
\hline 15 & $35.80 \times$ & $34.80 \%$ & $3.52 \%$ & $17.40 x$ & $19.00 x$ & \\
\hline 16 & 34.004 & $31.10 x$ & $2.79 \approx$ & $16.50 \times$ & $21.00 \%$ & \\
\hline 17 & $30.90 \%$ & $28.80 x$ & $1.77 \%$ & $15.60 \%$ & $19.40 \%$ & \\
\hline 18 & $28.50 x$ & $29.10 \%$ & $1.46 x$ & $15.10 x$ & $19.20 x$ & \\
\hline 19 & $26.60 x$ & $24.60 x$ & 1.408 & $14.40 x$ & $18.20 x$ & \\
\hline 20 & $24.60 \%$ & $22.30 x$ & $1.40 \%$ & $13.80 \%$ & 19.408 & \\
\hline 22 & Nunber of & Inner & 4. $18 x$ & Number of & Inner & \\
\hline 23 & iteration & is & $3.54 \%$ & iteration & is & \\
\hline 24 & linited to & 20 & 3. $39 x$ & linited to & 20 & \\
\hline 25 & & & $2.88 \%$ & & & \\
\hline 26 & & & $2.08 \%$ & & & \\
\hline 27 & & & $1.43 x$ & & & \\
\hline 28 & & & $1.68 \mathrm{x}$ & & & \\
\hline 29 & & & 1. $52 x$ & & & \\
\hline 30 & & & $3.69 x$ & & & \\
\hline 31 & & & 3.062 & & & \\
\hline 32 & & & $1.42 \mathrm{x}$ & & & \\
\hline 33 & & & $1.78 \%$ & & & \\
\hline 34 & & & $1.48 \%$ & & & \\
\hline 35 & & & $1.51 x$ & & & \\
\hline 36 & & & $1.48 x$ & & & \\
\hline 37 & & & $1.84 x$ & & & \\
\hline 38 & & & $1.70 x$ & & & \\
\hline 39 & & & $0.91 x$ & & & \\
\hline 40 & & & $1.27 x$ & & & \\
\hline 41 & & & 1. $76 x$ & & & \\
\hline 42 & & & $1.17 x$ & & & \\
\hline 43 & & & 1. $33 x$ & & & \\
\hline 44 & & & $1.28 x$ & & & \\
\hline 45 & & & $2.08 x$ & & & \\
\hline 46 & & & $2.01 x$ & & & \\
\hline 47 & & & $1.52 x$ & & & \\
\hline 48 & & & $2.96 \times$ & & & \\
\hline 49 & & & $2.93 x$ & & & \\
\hline 50 & & & $1.76 x$ & & & \\
\hline
\end{tabular}



APPENDIX II 



\section{APPENDDX II}

\section{Detailed MORSE-Calculated Results}

Two MORSE calculations were performed. For the first, the boundary source was input at the exit surface of choke no. 1. This is the same location as that for the source used in the TORT calculations described in Section 3. However, the source for this calculation was limited to the opening in the choke $(76 \mathrm{~cm}$ radius $)$. Selected results from this calculation were presented in Section 6. For the second calculation, the radius of the boundary source was extended $10 \mathrm{~cm}$ into the concrete surrounding the opening in choke no. 1 in order to determine why the first calculation underestimated the measured results.

Results for the two MORSE calculations are compared with measured results in Tables A.II. The following observations are made:

1. The contribution to the Bonner ball count rates of neutrons coming from the concrete of choke no. 1 is about $10 \%$.

2. Near the boundary source, it appears that the C/E values of the MORSE results are worse than those of the TORT results because of path-length stretching, which was used for minimizing the statistical error of the calculation. The path-length stretching caused an undersampling of neutron scattering events near the source and an oversampling further into the chaseway. Increasing the number of biasing regions and the number of scattered neutrons reaching the detector might improve the $\mathrm{C} / \mathrm{E}$ values, but that would require more labor and computer time.

3. Beyond position I-B-13 in the second leg of the chaseway, the MORSE C/E values are slightly better than those of DOT3.5, which used the bootstrapping method. However, it is very difficult to calculate accurate results in the third leg of the chaseway with a single MORSE calculation of the full configuration. While a bootstrapping method like that used with DOT3.5 is desirable, it is difficult to implement in a Monte Carlo code such as MORSE. Perhaps, there is a need for the development of a more efficient hybrid Monte Carlo method for calculating responses in the third leg of the chaseway or similar structures. 
Table A.II.1. Comparison of Measured and MORSE-Calculated 2-inch Bonner Ball Count Rates in the First Leg of the Chaseway.

\begin{tabular}{|c|c|c|c|c|c|c|c|c|}
\hline \multirow{2}{*}{ Point } & \multirow{2}{*}{$\begin{array}{l}\text { Distance } \\
\text { from } \\
\text { Na tank } \\
(\mathrm{cm})\end{array}$} & \multicolumn{2}{|c|}{ Case $A^{* 1}$} & \multicolumn{2}{|c|}{ Case $\mathrm{B}^{* *)}$} & \multirow{2}{*}{$\begin{array}{l}\text { Ratio } \\
\text { (B/A) }\end{array}$} & \multicolumn{2}{|c|}{$\mathrm{C} / \mathrm{E}$} \\
\hline & & $(\mathrm{cps} / \mathrm{W})$ & F.S.D. & $(\mathrm{cps} / \mathrm{W})$ & F.S.D. & & A & B \\
\hline I-A- 1 & 104.46 & $3.57 \times 10^{0}$ & 0.207 & $3.80 \times 100$ & 0.196 & 1.06 & 0.43 & 0.46 \\
\hline I-A- 2 & 134.94 & $3.60 \times 10^{0}$ & 0.035 & $4.02 \times 100$ & 0.035 & 1.11 & 0.60 & 0.67 \\
\hline 1-A- 3 & 165.42 & $3.60 \times 10^{00}$ & 0.032 & $3.72 \times 10^{0}$ & 0.018 & 1.03 & 0.79 & 0.82 \\
\hline I-A- 4 & 195.90 & $3.52 \times 10^{0}$ & 0.034 & $3.70 \times 10^{0}$ & 0.013 & 1.05 & 0.99 & 1.04 \\
\hline I-A- 5 & 218.92 & $2.45 \times 10^{0}$ & 0.041 & $2.92 \times 10^{0}$ & 0.015 & 1.19 & 0.79 & 0.94 \\
\hline 1-A- 7 & 249.71 & $1.81 \times 10^{0}$ & 0.042 & $2.15 \times 100$ & 0.015 & 1.18 & 0.71 & 0.84 \\
\hline ]-A- 8 & 280.19 & $1.10 \times 10^{0}$ & 0.022 & $1.41 \times 100$ & 0.019 & 1.28 & 0.52 & 0.66 \\
\hline$I-\Lambda-9$ & 310.67 & $1.09 \times 10^{0}$ & 0.023 & $1.22 \times 100$ & 0.021 & 1.12 & 0.59 & 0.66 \\
\hline$I-\Lambda-10$ & 341.15 & $8.92 \times 10^{-1}$ & 0.026 & $1.12 \times 10^{0}$ & 0.021 & 1.26 & 0.55 & 1) 69 \\
\hline$I-\Lambda-11$ & 371.63 & $8.73 \times 10^{-1}$ & 0.026 & $9.78 \times 10^{-1}$ & 0.047 & 1.12 & 0.59 & 0.66 \\
\hline I-A-12 & 402.11 & $8.38 \times 10^{-1}$ & 0.026 & $9.41 \times 10^{-1}$ & 0.046 & 1.12 & 0.61 & 0.68 \\
\hline I-A-13 & 425.61 & $8.53 \times 10^{-1}$ & 0.031 & $9.73 \times 10^{-1}$ & 0.044 & 1.14 & 0.62 & 0.71 \\
\hline
\end{tabular}

*) Source Radius $76 \mathrm{~cm}$ (Radius of Choke)

**) Source Radius $86 \mathrm{~cm}$ 
Table A.II.2. Comparison of Measured and MORSE-Calculated 3-inch Bonner Ball Count Rates in the First Leg of the Chaseway.

\begin{tabular}{|c|c|c|c|c|c|c|c|c|}
\hline \multirow{2}{*}{ Point } & \multirow{2}{*}{$\begin{array}{c}\text { Distance } \\
\text { from } \\
\text { Na tank } \\
\text { (cm) }\end{array}$} & \multicolumn{2}{|c|}{ Case $A^{*)}$} & \multicolumn{2}{|c|}{ Case $B^{* * 1}$} & \multirow{2}{*}{$\begin{array}{l}\text { Ratio } \\
\text { (B/A) }\end{array}$} & \multicolumn{2}{|c|}{$\mathrm{C} / \mathrm{F}$} \\
\hline & & $(\operatorname{cps} / W)$ & F.S.D. & $(\mathrm{cps} / \mathrm{W})$ & F.S.D. & & A & B \\
\hline$I-\Lambda-1$ & 104.46 & $4.56 \times 101$ & 0.154 & $5.51 \times 10^{1}$ & 0.125 & 1.21 & 0.56 & 0.68 \\
\hline I-A- 2 & 134.94 & $4.51 \times 10^{1}$ & 0.024 & $4.85 \times 10^{1}$ & 0.024 & 1.08 & 0.77 & 0.83 \\
\hline $\mathrm{I}-\mathrm{A}-3$ & 165.42 & $4.26 \times 10^{1}$ & 0.015 & $4.45 \times 10^{1}$ & 0.012 & 1.04 & 0.98 & 1.02 \\
\hline I-A- 4 & 195.90 & $3.98 \times 10^{1}$ & 0.007 & $4.36 \times 10^{1}$ & 0.013 & 1.10 & 1.18 & 1.29 \\
\hline I-A- 5 & 219.08 & $2.82 \times 101$ & 0.018 & $3.35 \times 10^{1}$ & 0.016 & 1.19 & 0.97 & 1.15 \\
\hline I-A- 7 & 249.56 & $2.03 \times 10^{1}$ & 0.021 & $2.41 \times 10^{1}$ & 0.010 & 1.19 & 0.86 & 1.03 \\
\hline$I-\Lambda-8$ & 280.04 & $1.17 \times 10^{1}$ & 0.016 & $1.49 \times 10^{1}$ & 0.013 & 1.27 & 0.60 & 0.76 \\
\hline$I-\Lambda-9$ & 310.52 & $1.15 \times 10^{1}$ & 0.016 & $1.26 \times 10^{1}$ & 0.016 & 1.10 & 0.69 & 075 \\
\hline 1-A-10 & 341.00 & $8.89 \times 10^{0}$ & 0.017 & $1.14 \times 10^{1}$ & 0.017 & 1.28 & 0.61 & 11.79 \\
\hline $\mathrm{I}-\mathrm{A}-11$ & 371.48 & $8.58 \times 10^{0}$ & 0.018 & $9.39 \times 10^{0}$ & 0.017 & 1.10 & 0.66 & 1174 \\
\hline I-A-12 & 401.96 & $8.11 \times 10^{0}$ & 0.018 & $8.89 \times 10^{0}$ & 0.019 & 1.10 & 0.66 & 1174 \\
\hline I-A-13 & 425.61 & $8.24 \times 10^{0}$ & 0.022 & $8.99 \times 10^{0}$ & 0.022 & 1.10 & 0.70 & 0.79 \\
\hline
\end{tabular}

*) Source Radius 76cm(Radius of Choke)

${ }^{* *}$ ) Source Radius $86 \mathrm{~cm}$ 
Table A.II.3. Comparison of Measured and MORSE-Calculated 6-inch Bonner Ball Count Rates in the First Leg of the Chaseway.

\begin{tabular}{|c|c|c|c|c|c|c|c|c|}
\hline \multirow{2}{*}{ Point } & \multirow{2}{*}{$\begin{array}{c}\text { Distance } \\
\text { from } \\
\text { Na tank } \\
\text { (cm) }\end{array}$} & \multicolumn{2}{|c|}{ Case $A^{*)}$} & \multicolumn{2}{|c|}{ Case $B^{* * 1}$} & \multirow{2}{*}{$\begin{array}{l}\text { Ratio } \\
\text { (B/A) }\end{array}$} & \multicolumn{2}{|c|}{$\mathrm{C} / \mathrm{E}$} \\
\hline & & $(\mathrm{cps} / \mathrm{W})$ & F.S.D. & $(\operatorname{cps} / W)$ & F.S.D. & & A & B \\
\hline I-A- 1 & 104.46 & $5.56 \times 10^{1}$ & 0.156 & $6.51 \times 10^{1}$ & 0.125 & 1.17 & 0.57 & 0.66 \\
\hline I-A-2 & 134.94 & $5.24 \times 10^{1}$ & 0.023 & $5.53 \times 10^{1}$ & 0.025 & 1.06 & 0.78 & 0.83 \\
\hline I-A-3 & 165.42 & $4.80 \times 10^{1}$ & 0.012 & $5.02 \times 10^{1}$ & 0.014 & 1.05 & 0.97 & 1.01 \\
\hline 1-A-4 & 195.90 & $4.52 \times 10^{1}$ & 0.007 & $4.90 \times 10^{1}$ & 0.010 & 1.08 & 1.19 & 1.29 \\
\hline I-A- 5 & 219.71 & $3.12 \times 10^{1}$ & 0.010 & $3.71 \times 10^{1}$ & 0.011 & 1.19 & 1.01 & 1.20 \\
\hline I- $\Lambda-7$ & 250.19 & $2.23 \times 10^{1}$ & 0.015 & $2.62 \times 10^{1}$ & 0.009 & 1.17 & 0.90 & 1.05 \\
\hline 1-A- 8 & 280.67 & $1.23 \times 10^{1}$ & 0.016 & $1.55 \times 10^{1}$ & 0.013 & 1.26 & 0.59 & 0.77 \\
\hline$[-\Lambda-9$ & 311.15 & $1.19 \times 10^{1}$ & 0.016 & $1.30 \times 10^{1}$ & 0.016 & 1.09 & 0.68 & 0.74 \\
\hline $1-A-10$ & 341.63 & $8.98 \times 10^{0}$ & 0.017 & $1.16 \times 10^{1}$ & 0.015 & 1.29 & 0.59 & 0.77 \\
\hline $1-\Lambda-11$ & 371.11 & $8.58 \times 10^{0}$ & 0.017 & $9.51 \times 10^{0}$ & 0.022 & 1.11 & 0.63 & 0.70 \\
\hline I-A-12 & 402.59 & $8.02 \times 10^{0}$ & 0.017 & $8.90 \times 10^{0}$ & 0.025 & 1.11 & 0.65 & 0.72 \\
\hline I-A-13 & 425.61 & $8.16 \times 10^{0}$ & 0.020 & $9.01 \times 10^{0}$ & 0.029 & 1.10 & 0.69 & 0.76 \\
\hline
\end{tabular}

*) Source Radius $76 \mathrm{~cm}$ (Radius of Choke)

**) Source Radius $86 \mathrm{~cm}$ 
Table A.II.4. Comparison of Measured and MORSE-Calculated 10-inch Bonner Ball Count Rates in the First Leg of the Chaseway.

\begin{tabular}{|c|c|c|c|c|c|c|c|c|}
\hline \multirow{2}{*}{ Point } & \multirow{2}{*}{$\begin{array}{l}\text { Distance } \\
\text { from } \\
\text { Na tank } \\
\text { (cm) }\end{array}$} & \multicolumn{2}{|c|}{ Case $A^{* 1}$} & \multicolumn{2}{|c|}{ Case $B^{* * 1}$} & \multirow{2}{*}{$\begin{array}{l}\text { Ratio } \\
\text { (B/A) }\end{array}$} & \multicolumn{2}{|c|}{$\mathrm{C} / \mathrm{E}$} \\
\hline & & $(\mathrm{cps} / \mathrm{W})$ & F.S.D. & $(\operatorname{cps} / W)$ & F.S.D. & & A & B \\
\hline I-A- 1 & 104.46 & $9.74 \times 10^{0}$ & 0.152 & $1.11 \times 10^{1}$ & 0.136 & 1.14 & 0.55 & 0.63 \\
\hline I-A- 2 & 134.94 & $9.27 \times 10^{0}$ & 0.026 & $9.83 \times 10^{0}$ & 0.026 & 1.06 & 0.74 & 0.79 \\
\hline I-A- 3 & 165.42 & $8.52 \times 10^{0}$ & 0.014 & $8.87 \times 10^{0}$ & 0.014 & 1.04 & 0.93 & 0.97 \\
\hline$I-A-4$ & 195.90 & $7.97 \times 10^{0}$ & 0.008 & $8.65 \times 10^{0}$ & 0.011 & 1.09 & 1.16 & 1.26 \\
\hline I-A - 5 & 220.03 & $5.53 \times 10^{0}$ & 0.013 & $6.54 \times 10^{0}$ & 0.012 & 1.18 & 0.96 & 1.14 \\
\hline I-A - 7 & 250.19 & $3.91 \times 10^{0}$ & 0.015 & $4.62 \times 10^{0}$ & 0.011 & 1.18 & 0.84 & 0.99 \\
\hline I-A- 8 & 280.67 & $2.15 \times 10^{0}$ & 0.018 & $2.77 \times 10^{0}$ & 0.016 & 1.29 & 0.54 & 0.71 \\
\hline$[-\Lambda-9$ & 311.15 & $2.08 \times 10^{0}$ & 0.018 & $2.28 \times 10^{0}$ & 0.016 & 1.10 & 0.63 & 0.69 \\
\hline $1-\Lambda-10$ & 341.63 & $1.50 \times 10^{0}$ & 0.019 & $2.04 \times 10^{0}$ & 0.018 & 1.36 & 0.55 & 0.72 \\
\hline $1-A-11$ & 372.11 & $1.49 \times 10^{0}$ & 0.018 & $1.66 \times 10^{0}$ & 0.022 & 1.11 & 0.59 & 11.60 \\
\hline$[-\Lambda-12$ & 402.59 & $1.39 \times 10^{0}$ & 0.018 & $1.55 \times 10^{0}$ & 0.025 & 1.12 & 0.60 & 0.67 \\
\hline $1-A-13$ & 424.66 & $1.41 \times 10^{0}$ & 0.020 & $1.56 \times 10^{0}$ & 0.028 & 1.11 & 0.64 & 0.71 \\
\hline
\end{tabular}

*) Source Radius 76cm(Radius of Choke)

**) Source Radius $86 \mathrm{~cm}$ 
Table A.II.5. Comparison of Measured and MORSE-Calculated 2-inch Bonner Ball Count Rates in the Second Leg of the Chaseway.

\begin{tabular}{|c|c|c|c|c|c|c|c|c|}
\hline \multirow{2}{*}{ Point } & \multirow{2}{*}{$\begin{array}{c}\text { Distance } \\
\text { from } \\
\text { 1st.Leg } \\
\text { Center } \\
\text { (cm) }\end{array}$} & \multicolumn{2}{|c|}{ Case A*) } & \multicolumn{2}{|c|}{ Case $B^{* *}$} & \multirow{2}{*}{$\begin{array}{l}\text { Ratio } \\
\text { (B/A) }\end{array}$} & \multicolumn{2}{|c|}{$\mathrm{C} / \mathrm{Ti}$} \\
\hline & & $(\mathrm{cps} / \mathrm{W})$ & F.S.D. & $(\mathrm{cps} / \mathrm{W})$ & F.S.D. & & A & $\mathbf{B}$ \\
\hline I-B- 1 & -59.70 & - & - & - & - & - & - & - \\
\hline I-B- 2 & -29.20 & - & - & - & - & - & - & - \\
\hline I-B- 3 & 1.30 & - & - & - & - & - & - & - \\
\hline $1-B-4$ & 31.80 & - & - & - & - & - & - & - \\
\hline $\mathrm{I}-\mathrm{B}-5$ & 62.20 & - & - & - & - & - & - & - \\
\hline I-B- 6 & 92.70 & $9.78 \times 10^{-1}$ & 0.019 & $1.19 \times 10^{0}$ & 0.015 & 1.22 & 0.80 & 0.97 \\
\hline I-B- 7 & 123.20 & $4.98 \times 10^{-1}$ & 0.030 & $5.92 \times 10^{-1}$ & 0.025 & 1.19 & 0.81 & 0.96 \\
\hline I-B- 8 & 153.70 & $2.58 \times 10^{-1}$ & 0.050 & $3.08 \times 10^{-1}$ & 0.034 & 1.19 & 0.68 & 0.81 \\
\hline I-B- 9 & 184.20 & $1.88 \times 10^{-1}$ & 0.069 & $2.25 \times 10^{-1}$ & 0.048 & 1.20 & 0.72 & 0.86 \\
\hline $1-13-10$ & 214.60 & $1.48 \times 10^{-1}$ & 0.089 & $1.71 \times 10^{0}$ & 0.069 & 1.16 & 0.75 & 0.87 \\
\hline $1-B-11$ & 245.10 & $1.26 \times 10^{-1}$ & 0.119 & $1.36 \times 10^{-1}$ & 0.094 & 1.08 & 0.84 & 0.91 \\
\hline $1-B-12$ & - & - & - & - & - & - & - & - \\
\hline I-B-13 & 275.60 & $1.04 \times 10^{-1}$ & 0.144 & $1.04 \times 10^{-1}$ & 0.098 & 1.00 & 0.89 & 0.89 \\
\hline I-B-14 & 335.30 & - & & - & - & - & - & - \\
\hline I-B-15 & 381.00 & - & & - & - & - & - & - \\
\hline J-B-16 & 502.90 & - & & - & - & - & - & - \\
\hline I-B-17 & 624.80 & - & & - & - & - & - & - \\
\hline 1-B-18 & $746.80^{\prime \prime \prime}$ & - & & - & - & - & - & - \\
\hline
\end{tabular}

*) Source Radius 76 cm(Radius of Choke)

**) Source Radius $86 \mathrm{~cm}$

\#) Center line of'Third Leg 
Table A.II.6. Comparison of Measured and MORSE-Calculated 3-inch Bonner Ball Count Rates in the Second Leg of the Chaseway.

\begin{tabular}{|c|c|c|c|c|c|c|c|c|}
\hline \multirow{2}{*}{ Point } & \multirow{2}{*}{$\begin{array}{c}\text { Distance } \\
\text { from } \\
\text { 1st.Leg } \\
\text { Center } \\
\text { (cm) }\end{array}$} & \multicolumn{2}{|c|}{ Case $A^{* 1}$} & \multicolumn{2}{|c|}{ Case $\left.B^{* *}\right)$} & \multirow{2}{*}{$\begin{array}{l}\text { Ratio } \\
\text { (B/A) }\end{array}$} & \multicolumn{2}{|c|}{$\mathrm{C} / \mathrm{H}:$} \\
\hline & & $(\operatorname{cps} / W)$ & F.S.D. & $(\mathrm{cps} / \mathrm{W})$ & F.S.D. & & A & B \\
\hline I-B- 1 & -61.00 & $1.48 \times 10^{1}$ & 0.022 & $1.78 \times 10^{3}$ & 0.032 & 1.20 & 0.87 & 1.05 \\
\hline I-B- 2 & -30.50 & $1.15 \times 10^{1}$ & 0.020 & $1.41 \times 10^{1}$ & 0.025 & 1.23 & 0.69 & 0.85 \\
\hline I-B- 3 & 0.00 & $1.15 \times 10^{1}$ & 0.016 & $1.26 \times 10^{1}$ & 0.016 & 1.10 & 0.70 & 0.76 \\
\hline I-B- 4 & 30.50 & $1.07 \times 10^{1}$ & 0.020 & $1.33 \times 10^{1}$ & 0.038 & 1.24 & 0.66 & 0.83 \\
\hline I-B -5 & 61.00 & $1.28 \times 10^{1}$ & 0.018 & $1.49 \times 10^{1}$ & 0.029 & 1.16 & 0.87 & 1.01 \\
\hline $1-B-6$ & 91.40 & $1.13 \times 10^{1}$ & 0.011 & $1.34 \times 10^{1}$ & 0.012 & 1.19 & 1.00 & 1.19 \\
\hline I-B- 7 & 121.90 & $5.56 \times 10^{0}$ & 0.019 & $6.44 \times 10^{0}$ & 0.021 & 1.16 & 1.13 & 1.29 \\
\hline I-B- 8 & 152.40 & $2.46 \times 10^{0}$ & 0.035 & $2.97 \times 10^{0}$ & 0.037 & 1.21 & 0.86 & 1.03 \\
\hline$J-B-9$ & 182.90 & $1.76 \times 10^{0}$ & 0.046 & $2.16 \times 10^{0}$ & 0.053 & 1.23 & 0.91 & 3.12 \\
\hline I-B-10 & 213.40 & $1.34 \times 10^{0}$ & 0.058 & $1.68 \times 10^{0}$ & 0.077 & 1.25 & 0.94 & 1.17 \\
\hline 1-B-11 & 243.80 & $1.08 \times 10^{0}$ & 0.071 & $1.33 \times 10^{0}$ & 0.100 & 1.23 & 1.01 & 1.24 \\
\hline $1-B-12$ & - & - & - & - & - & - & - & - \\
\hline I-B-13 & 274.30 & $8.63 \times 10^{-1}$ & 0.083 & $1.02 \times 10^{0}$ & 0.102 & 1.18 & 1.05 & 1.24 \\
\hline 1-B-14 & 335.30 & $4.93 \times 10^{-1}$ & 0.102 & - & - & - & 1.08 & - \\
\hline I-B-15 & 381.00 & $3.07 \times 10^{-1}$ & 0.101 & $\because$ & - & - & 1.06 & - \\
\hline $1-B-16$ & 502.90 & $1.28 \times 10^{-1}$ & 0.116 & -1 & - & - & 1.08 & - \\
\hline $1-B-17$ & 624.80 & $8.09 \times 10^{-2}$ & 0.146 & - & - & - & 1.19 & - \\
\hline 1-B-18 & $746.80^{\prime \prime \prime}$ & $5.32 \times 10^{-2}$ & 0.130 & -1 & - & - & 1.17 & - \\
\hline
\end{tabular}

*) Source Radius $76 \mathrm{~cm}$ (Radius of Choke)

**) Source Radius $86 \mathrm{~cm}$

\#) Center line of'Third Leg 
Table A.II.7. Comparison of Measured and MORSE-Calculàted 6-inch Bonner Ball Count Rates in the Second Leg of the Chaseway.

\begin{tabular}{|c|c|c|c|c|c|c|c|c|}
\hline \multirow{2}{*}{ Point } & \multirow{2}{*}{$\begin{array}{c}\text { Distance } \\
\text { from } \\
\text { 1st.Leg } \\
\text { Center } \\
\text { (cm) }\end{array}$} & \multicolumn{2}{|c|}{ Case $A^{* 1}$} & \multicolumn{2}{|c|}{ Case $B^{* * 1}$} & \multirow{2}{*}{$\begin{array}{l}\text { Ratio } \\
\text { (B/A) }\end{array}$} & \multicolumn{2}{|c|}{$\mathrm{C} / \mathrm{E}$} \\
\hline & & $(\operatorname{cps} / W)$ & F.S.D. & $(\mathrm{cps} / \mathrm{W})$ & F.S.D. & & A & B \\
\hline I-B- 1 & -60.60 & $1.55 \times 10^{1}$ & 0.018 & $1.87 \times 10^{1}$ & 0.025 & 1.21 & 0.87 & 1.05 \\
\hline I-B- 2 & -30.20 & $1.18 \times 10^{1}$ & 0.016 & $1.45 \times 10^{1}$ & 0.019 & 1.23 & 0.65 & 0.80 \\
\hline I-B- 3 & 0.30 & $1.19 \times 10^{1}$ & 0.016 & $1.30 \times 10^{1}$ & 0.016 & 1.09 & 0.65 & 0.71 \\
\hline I-B - 4 & 30.80 & $1.10 \times 10^{1}$ & 0.018 & $1.38 \times 10^{1}$ & 0.025 & 1.25 & 0.63 & 0.79 \\
\hline I-B- 5 & 61.30 & $1.35 \times 101$ & 0.015 & $1.59 \times 10^{1}$ & 0.020 & 1.18 & 0.85 & 1.01 \\
\hline I-B- 6 & 91.80 & $1.23 \times 10^{1}$ & 0.012 & $1.44 \times 10^{1}$ & 0.013 & 1.17 & 1.06 & 1.24 \\
\hline I-B- 7 & 122.20 & $5.78 \times 10^{0}$ & 0.019 & $6.60 \times 10^{0}$ & 0.022 & 1.14 & 1.17 & 1.34 \\
\hline I-B- 8 & 152.70 & $2.34 \times 10^{0}$ & 0.035 & $2.85 \times 10^{0}$ & 0.041 & 1.22 & 0.86 & 1.04 \\
\hline I-B- 9 & 183.20 & $1.64 \times 10^{0}$ & 0.041 & $2.05 \times 10^{0}$ & 0.057 & 1.25 & 0.90 & 1.13 \\
\hline I-B-10 & 213.70 & $1.22 \times 10^{0}$ & 0.050 & $1.60 \times 10^{0}$ & 0.079 & 1.31 & 0.95 & 1.24 \\
\hline $1-B-11$ & 244.20 & $9.56 \times 10^{-1}$ & 0.057 & $1.27 \times 10^{0}$ & 0.097 & 1.33 & 0.75 & 1.27 \\
\hline I-B-12 & - & - & - & - & - & - & - & - \\
\hline I-B-13 & 274.30 & $7.49 \times 10^{-1}$ & 0.064 & $9.84 \times 10^{-1}$ & - & 1.31 & 0.76 & 1.29 \\
\hline I-B-14 & 335.60 & $4.75 \times 10^{-1}$ & 0.098 & - & - & - & 1.14 & - \\
\hline I-B-15 & 381.00 & $2.95 \times 10^{-1}$ & 0.094 & - & - & - & 1.10 & - \\
\hline I-B-16 & 502.90 & $1.19 \times 10^{-1}$ & 0.099 & - & - & - & 1.09 & - \\
\hline I-B-17 & 624.80 & $7.15 \times 10^{-2}$ & 0.117 & - & - & - & 1.16 & - \\
\hline 1-B-18 & $746.80^{\prime \prime \prime}$ & $4.69 \times 10^{-2}$ & 0.100 & - & - & - & 1.16 & - \\
\hline
\end{tabular}

*) Source Radius $76 \mathrm{~cm}$ (Radius of Choke)

**) Source Radius $86 \mathrm{~cm}$

\#) Center line of 'Third Leg 
Table A.II.8. Comparison of Measured and MORSE-Calculated 10-inch Bonner Ball Count Rates in the Second Leg of the Chaseway.

\begin{tabular}{|c|c|c|c|c|c|c|c|c|}
\hline \multirow{2}{*}{ Point } & \multirow{2}{*}{$\begin{array}{l}\text { Distance } \\
\text { from } \\
\text { 1st.Leg } \\
\text { Center } \\
\text { (cm) }\end{array}$} & \multicolumn{2}{|c|}{ Case $A^{* 1}$} & \multicolumn{2}{|c|}{ Case $B^{* * 1}$} & \multirow{2}{*}{$\begin{array}{l}\text { Ratio } \\
\text { (B/A) }\end{array}$} & \multicolumn{2}{|c|}{$\mathrm{C} / \mathrm{E}$} \\
\hline & & $(\operatorname{cps} / W)$ & F.S.D. & $(\mathrm{cps} / \mathrm{W})$ & F.S.D. & & A & B \\
\hline I-B- 1 & -61.00 & $2.69 \times 10^{0}$ & 0.018 & $2.59 \times 10^{0}$ & 0.025 & 0.96 & 0.81 & 0.78 \\
\hline I-B- 2 & -30.50 & $2.05 \times 10^{0}$ & 0.016 & $2.00 \times 100$ & 0.019 & 0.98 & 0.61 & 0.59 \\
\hline I-B -3 & 0.00 & $2.08 \times 10^{0}$ & 0.018 & $2.28 \times 10^{0}$ & 0.016 & 1.10 & 0.59 & 0.65 \\
\hline I-B- 4 & 30.50 & $1.91 \times 10^{0}$ & 0.018 & $1.90 \times 10^{0}$ & 0.024 & 0.99 & 0.57 & 0.57 \\
\hline $\mathrm{I}-\mathrm{B}-5$ & 61.00 & $2.35 \times 10^{0}$ & 0.017 & $2.22 \times 10^{0}$ & 0.021 & 0.94 & 0.75 & 0.71 \\
\hline I-B- 6 & 91.40 & $2.19 \times 10^{0}$ & 0.012 & $2.55 \times 100$ & 0.014 & 1.16 & 1.00 & 1.16 \\
\hline [-B- 7 & 121.90 & $1.02 \times 10^{0}$ & 0.019 & $1.16 \times 10^{0}$ & 0.022 & 1.14 & 1.09 & 1.24 \\
\hline I-B- 8 & 152.40 & $3.99 \times 10^{-1}$ & 0.035 & $4.89 \times 10^{-1}$ & 0.042 & 1.23 & 0.78 & 0.96 \\
\hline I-B- 9 & 182.90 & $2.80 \times 10^{-1}$ & 0.040 & $3.51 \times 10^{-1}$ & 0.056 & 1.25 & 0.82 & 1.03 \\
\hline $1-B-10$ & 213.40 & $2.08 \times 10^{-1}$ & 0.049 & $2.73 \times 10^{-1}$ & 0.078 & 1.31 & 0.84 & 1.11 \\
\hline 1-B-11 & 243.80 & $1.62 \times 10^{-1}$ & 0.056 & $2.16 \times 10^{-1}$ & 0.095 & 1.33 & 0.89 & 1.18 \\
\hline I-B-12 & - & - & - & - & - & - & - & - \\
\hline $1-B-13$ & 274.30 & $1.26 \times 10^{-1}$ & 0.063 & $1.67 \times 10^{-1}$ & 0.096 & 1.33 & 0.89 & 1.18 \\
\hline I-B-14 & 335.30 & $8.11 \times 10^{-2}$ & 0.097 & - & - & - & 1.04 & - \\
\hline I-B-15 & 381.00 & $5.04 \times 10^{-2}$ & 0.093 & - & - & - & 1.06 & - \\
\hline I-B-16 & 502.90 & $2.03 \times 10^{-2}$ & 0.096 & - & - & - & 1.07 & - \\
\hline 1-B-17 & 624.80 & $1.21 \times 10^{-2}$ & 0.013 & - & - & - & 1.14 & - \\
\hline I-B-18 & $746.80^{\# \prime}$ & $7.94 \times 10^{-3}$ & 0.107 & - & - & - & 1.01 & - \\
\hline
\end{tabular}

*) Source Radius $76 \mathrm{~cm}$ (Radius of Choke)

**) Source Radius $86 \mathrm{~cm}$

\#) Center line of'Third Leg 
\llcorner

- 
ORNL/TM-11641

Dist Cat. UC-535

\section{INTERNAL DISTRIBUTION}

1. B. R. Appleton

2. J. A. Bucholz

3. R. L. Childs

4. J. D. Drischler

5. M. B. Emmett

6. W. W. Engle, Jr.

7. C. $\mathrm{Y} . \mathrm{Fu}$

8. L. B. Holland

9. F. J. Homan

10. J. L. Hull

11. D. T. Ingersoll

12. J. O. Johnson

13. R. E. Maerker

14. F. J. Muckenthaler

15. F. R. Mynatt
16-20. J. V. Pace III

21. W. A. Rhoades

22. R. W. Roussin

23. R. T. Santoro

24-26. A. Shono

27-31. C. O. Slater

32. R. C. Ward

33. L. R. Williams

34. EPMD Reports Office

35-36. Laboratory Records Dept.

37. Laboratory Records, ORNL-RC

38. Document Reference Section

39. Central Research Library

40. ORNL Patent Section

\section{EXTERNAL DISTRIBUTION}

41. Office of Assistant Manager for Energy Research and Development, DOE-OR, P.O. Box 2008, Oak Ridge, TN 37831-6269

42-51. Office of Scientific and Technical Information, P.O. Box 62, Oak Ridge, TN 37831

52. L. F. Blankner, Energy Research and Development, DOE-OR, P.O. Box 2008, Oak Ridge, TN 37831-6269

53. Prof. R. W. Brockett, Pierce Hall, Harvard University, 29 Oxford Street, Cambridge, MA 02138

54. L. L. Carter, Westinghouse-Hanford Company, 400 Area Trailer, 1, P.O. Box 1970, Richland, WA 99352

55. K. Chatani, Experimental Reactor Division, Power Reactor \& Nuclear Development Corporation, 4002 Nanita, Oarai, Ibaraki 311-13, Japan

56. R. K Disney, Westinghouse Electric Company, P.O. Box 158, Madison, PA 15663

57. Prof. J. J. Dorning, Department of Nuclear Engineering and Engineering Physics, Thornton Hall, University of Virginia, Charlottesville, Virginia 22901 
58. P. B. Hemmig, Safety and Physics Branch, Office of Technology Support Programs, DOE-Washington, Washington, DC 20585

59. Dr. James E. Leiss, Route 2, Box 142C, Broadway, VA 22815

60. Prof. Neville Moray, Department of Mechanical and Industrial Engineering, 1206 West Green Street, Urbana, IL 61801

61. K. Takahashi, Power Reactor and Nuclear Fuel Development Corporation, Sankaido Building, 9-13, 1-Chrome, Minato-Ku, Tokyo, Japan

62. M. Tsutsumi, Power Reactor and Nuclear Fuel Development Corporation, Washington, Suite 715, 2600 Virginia Avenue NW, Washington, DC 20037

63. Prof. Mary F. Wheeler, Department of Mathematical Sciences, Rice University, P.O. Box 1892, Houston, TX 77251

64-129. Given distribution as shown in DOE/OSTI-4500-R75, LMFBR-Reactor Core Systems, UC-535 